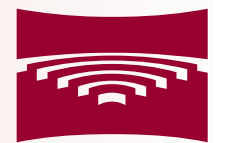

RīGAs STRADina UNIVERSITĀTE

\title{
Zane Dāvidsone
}

\section{TEMPOROMANDIBULĀRO LOCĪTAVU ARTRĪTA ATTĪSTĪBU IETEKMĒJOŠIE FAKTORI, KLİNISKIE UN RADIOLOĢISKIE SIMPTOMI BĒRNIEM AR JUVENILU IDIOPĀTISKU ARTRĪTU}

Promocijas darbs medicinnas doktora zinātniskā grāda iegūšanai Specialitāte - pediatrija, bērnu reimatoloǵija 


\title{
TEMPOROMANDIBULĀRO LOCĪTAVU ARTRĪTA ATTİSTĪBU IETEKMĒJOŠIE FAKTORI, KLINNISKIE UN RADIOLOG̣ISKIE SIMPTOMI BĒRNIEM AR JUVENILU IDIOPĀTISKU ARTRĪTU
}

\author{
Promocijas darbs \\ medicīnas doktora zinātniskā grāda iegūšanai
}

Specialitāte - pediatrija, bērnu reimatologiija

Darba zinātniskā vadītāja:

Dr. med. profesore Valda Staṇēviča

Rīga, 2018 


\begin{abstract}
ANOTĀCIJA
Juvenils idiopātisks artrīts (JIA) ir biežākā reimatoloǵiskā slimība bērnu vecumā, kuras gadījumā iekaisums var skart jebkuru locītavu, tostarp arī temporomandibulārās locītavas (TML). Šo locītavu iekaisums var radīt ilgtermiṇa sekas - dentofaciālus bojājumus un funkcionālus traucējumus, kas būtiski ietekmē pacienta dzīves kvalitāti. Zelta standarts temporomandibulāro locītavu artrīta diagnostikā ir magnētiskās rezonanses izmeklējums (MRI) ar kontrastvielu, kas ir invazīva, dārga metode. Lai noskaidrotu JIA slimnieku grupu, kuriem ir indikācijas MRI veikšanai, nepieciešams noskaidrot tos faktorus, kas ietekmē TML artrīta attīstību, kā arī zināt, kuri no subjektīvajiem un/vai objektīvajiem simptomiem biežāk asociējas ar artrīta atradi MRI.
\end{abstract}

Darba mērķis bija noskaidrot TML artrīta attīstību ietekmējošos demogrāfiskos, slimību raksturojošos klīniskos, laboratoriskos un ǵenētiskos faktorus, kā arī klīniskos (subjektīvos un objektīvos) un radiologiskos simptomus un to savstarpējo saistību bērniem ar juvenilu idiopātisku artrītu.

Pētîjums bija prospektīvs, šķērsgriezuma, veidots no četrām dạ̣ām: 1) analizēti pacientu grupas demogrāfiskie un slimību raksturojošie rādītāji; 2) noteikti TML artrīta attīstību ietekmējošie faktori, tai skaitā HLA II klases alēles pacientu grupās ar TML artrīta pazīmēm MRI un bez tām; 3) analizēti subjektīvie un objektīvie simptomi un to saistība ar MRI; 4) analizēti MRI rezultāti un to atšķirīibas JIA pacientiem ar un bez TML artrīta subjektīvajiem un/vai objektīvajiem simptomiem.

Pētījumā tika iekḷauts 91 JIA pacients, kuriem laikā no 2010. līidz 2015. gadam veikts MRI ar kontrastvielu: 80 pacienti bija ar subjektīviem un/vai objektīviem TML artrīta simptomiem, bet 11 pacienti - bez simptomiem (asimptomātiski). TML artrīta attīstību ietekmējošie faktori, tai skaitā HLA II klases alēles, tika analizētas atkarībā no MRI atrades 72 pacientiem tika konstatētas TML artrīta pazīmes, 19 pacientiem to nebija. Pētījuma pacientiem un 100 veselu indivīdu kontroles grupai tika veikta HLA II klases alẹlu DRB1, DQA1, DQB1 genotipēšana. Līdz šim nav veikti pētījumi par HLA II klases alēlēm JIA slimniekiem ar TML artrītu.

No visiem demogrāfiskiem, slimību raksturojošiem klīniskiem un laboratoriskiem TML artrīta attīstību ietekmējošajiem faktoriem CRP bija statistiski ticami augstāks pacientu grupā ar artrīta MRI atradi. Tika konstatēts, ka JIA ar TML artrītu pastāv ǵenētiska predispozīja. Risks TML artrīta attīstībai bija pacientiem ar alēlēm DRB1*07:01, DRB1*13:01, DRB1*15:01, savukārt aizsargājoša ietekme bija alēlēm DRB1*08:01, 
DRB1*16:01, DRB*17:01 un DQB1*06:01. Tika konstatēts, ka DQA1*05:01, DQB1*03:01 un DRB*11:01 alēlēm ir mazāka saistība ar risku attīstīties hroniskām artrīta izmaināam TML.

Vērtējot subjektīvos un objektīvos simptomus pacientu grupās ar dažādu MRI atradi, tika noskaidrots, ka ticami vairāk subjektīvo un objektīvo sūdzību bija grupā ar aktīva un hroniska iekaisuma pazīmju kombināciju MRI. Saistība starp pozitīvu MRI atradi un demogrāfiskajiem, klīniskajiem un laboratoriskajiem rādītājiem tika noteikta, izmantojot logistiskās regresijas modeli, kurā objektīvo simptomu skaits statistiski ticami prognozēja pozitīvu MRI atradi - objektīvo simptomu skaitam pieaugot par vienu simptomu, varbūtība, ka būs pozitīiva MRI atrade, pieauga 2,3 reizes.

JIA slimniekiem ar subjektīviem un/vai objektīviem TML artrīta simptomiem MRI atradē biežāk nekā asimptomātiskajiem slimniekiem bija aktīva un hroniska iekaisuma pazīmju kombinācija.

Pētījuma rezultāti var palīdzēt TML artrīta diagnostikā un terapijas taktikas izvēlē slimniekiem ar juvenilu idiopātisku artrītu. 


\section{SUMMARY}

Juvenile idiopathic arthritis (JIA) is the most frequent rheumatologic disease in childhood. Any joint can be involved and also temporomandibular joints (TMJ). Longterm consequences of inflammation in these joints can be growth disturbancies with changes in shape and appearance and functional impairment of dentofacial region what in turn can lead to reduced quality of life. Magnetic resonance imaging (MRI) with contrast enhancement is the golden standard for diagnostics of TMJ arthriti. It is invasive and expensive method. To clarify those JIA patients who have indications for MRI it is important to understand factors what influence development of TMJ arthritis and also to know what subjective and/or objective symptoms are reflecting MRI findings.

The objective of our study was to determine factors what influence development of TMJ arthritis including demographic, disease characterising clinical, laboratory and genetic factors and also to determine those clinical - subjective and objective symptoms what are connected with radiological symptoms.

The study was prospective, cross sectional study consisting from four parts: 1) demographic and disease characterising clinical data of JIA patients group where analysed; 2) to determine factors what influences TMJ arthritis development different factors, including HLA II class alleles where analysed in two main study groups - with MRI findings consistent with TMJ arthritis and those without signs of arthritis in MRI; 3) patients subjective and objective TMJ symptoms where analysed in connection with MRI; 4) MRI results where analysed and compared in patients with TMJ arthritis symptoms and without them (asymptomatic patients).

91 JIA patients where included in the study to whom MRI of TMJ with contrast enhancement was done from years 2010 to 2015. 80 patients had subjective and/or objective TMJ arthritis symptoms and 11 JIA patients without symptoms where included. Factors what influence TMJ arthritis development including HLA II class alleles where analysed in two main groups according to MRI findings - 72 patients had MRI findings consistent with TMJ arthritis (MRI positive group) and 19 patients where with no arthritis signs in MRI (MRI negative group). HLA II class alleles DRB1, DQA1, DQB1 where genotyped in 91 JIA patients group and 100 healthy controls.

From all demographic, disease characterising clinical and laboratory factors the only one who was statisticaly significant higher in MRI positive group was C-reactive protein (CRP). We found that there is genetic predisposition for development of TMJ arthritis. Till this there has been no studies about HLA II class alleles in JIA patients with TMJ arthritis. In 
our study risk for development of TMJ arthritis was found to be in patients with alleles DRB1*07:01, DRB1*13:01, DRB1*15:01. Alleles DRB1*08:01, DRB1*16:01, DRB*17:01 and DQB1*06:01 where found to be associated with less risk for development of TMJ arthritis. Alleles DQA1*05:01, DQB1*03:01 and DRB*11:01 were found to be connected with less risk for chronic inflammatory signs development in TMJ.

It was found that there where more subjective and objective clinical symptoms in the group with active and chronic inflammatory signs combination in MRI of TMJ. Demographic, clinical and laboratory factors were analysed using logistic regression model and it was found that objective signs count predict positive MRI findings- if objective findings increased by one unit, probability for positive MRI findig was 2,3.

There were more patients with active and chronic inflammatory signs in MRI of TMJ in the group of symptomatic patients than in patients with no subjective and/or objective TMJ arthritis signs.

The study will help in the diagnostics of TMJ arthritis in JIA patients what further will help to decide about the treatment. 


\section{SATURS}

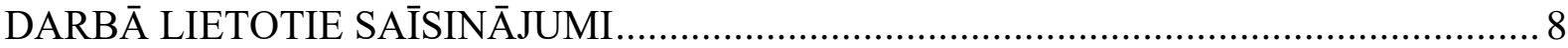

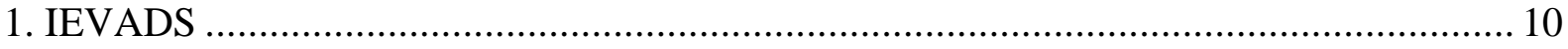

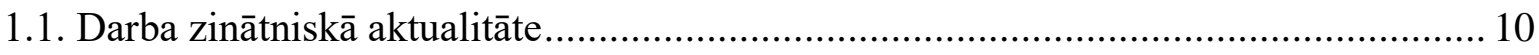

1.2. Darba hipotēzes, mērķis, uzdevumi ............................................................. 12

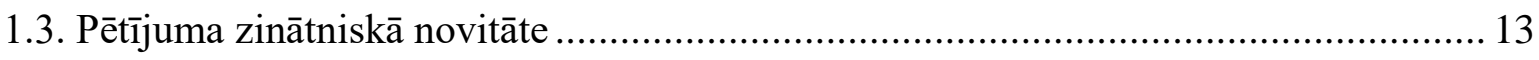

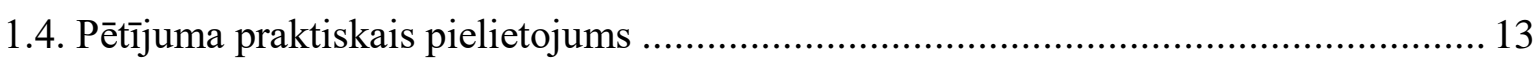

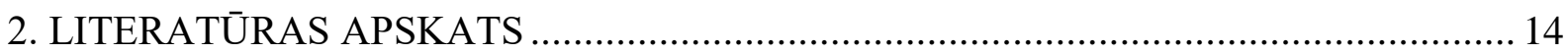

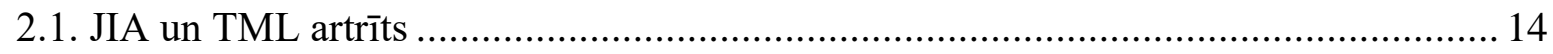

2.1.1. JIA - definīcija, etioloǵija, patoǵenēze, klasifikācija un klīniskā aina............. 14

2.1.2. TML anatomiskās īpatnības ...................................................................... 16

2.1.3. TML artrīta izplatība JIA slimniekiem .................................................. 17

2.1.4. TML artrīta ietekme uz kraniofaciālā reǵiona attīstību,
morfologiju un funkcijām .......................................................................... 18

2.2. TML artrīta attīstību ietekmējošie faktori ....................................................... 20



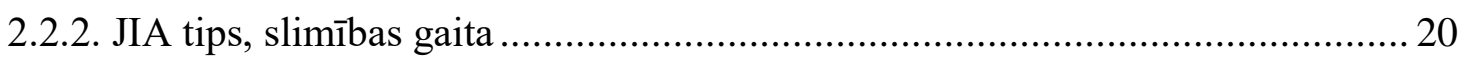

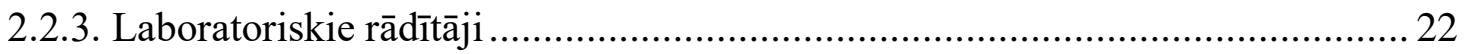

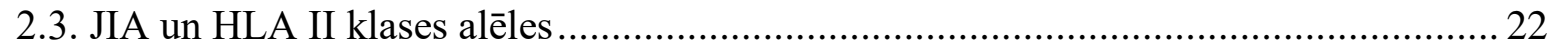

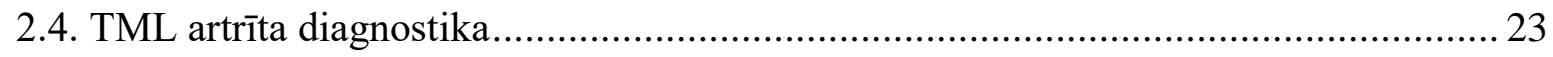

2.4.1. Subjektīvās sūdzības, objektīvā klīniskā atrade, TML artrīta skrīnings ............. 23

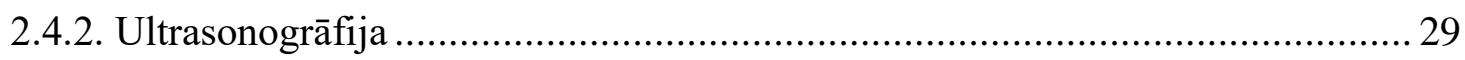

2.4.3. Konvencionālā rentgenogramma, datortomogrāfija un konusa staru

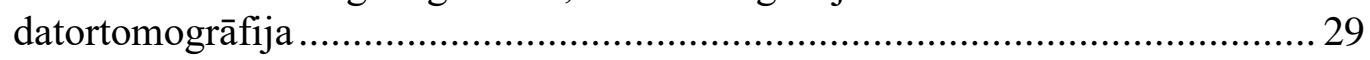

2.4.4. Magnētiskās rezonanses izmeklējums ........................................................ 30

2.4.5. Agrīnas un kombinētas diagnostikas nozīme .................................................. 33

2.5. TML artrīta vispārējās un lokālās terapijas iespējas .................................................. 34

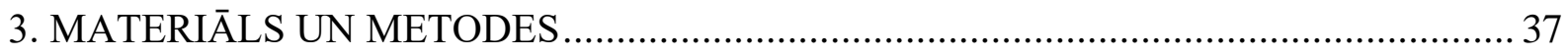

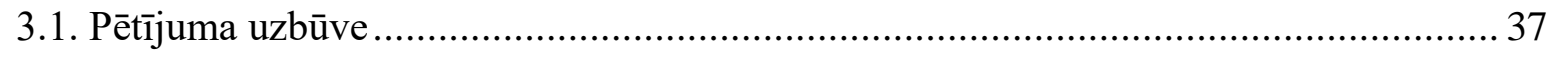

3.2. Pētījuma subjektu datu atlase un pētījuma populācijas raksturojums ........................ 37

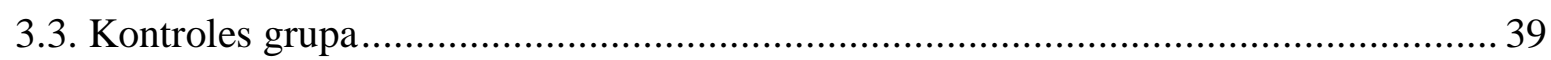

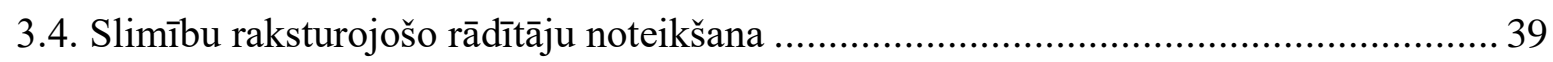

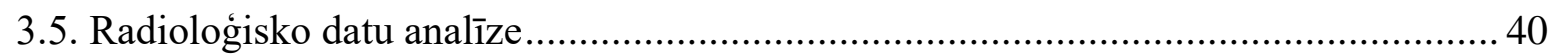

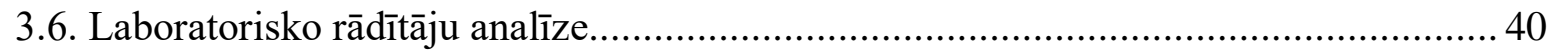

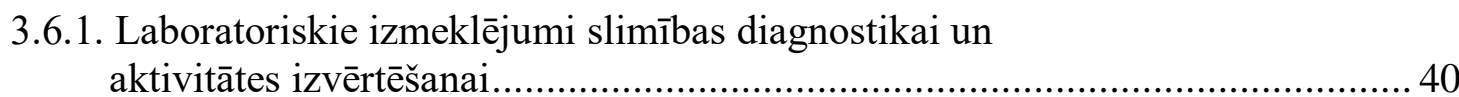

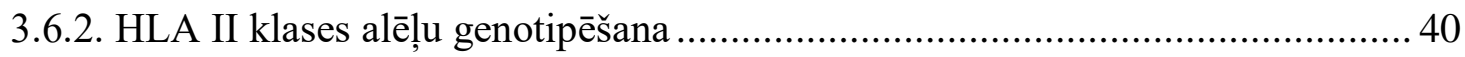


3.7. TML artrìta piecu soḷ skrīnings.................................................................... 41

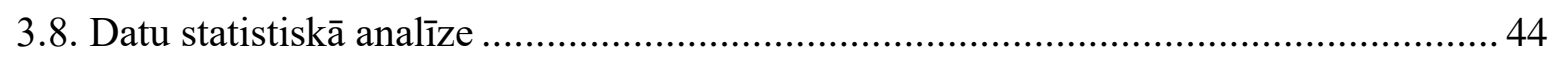

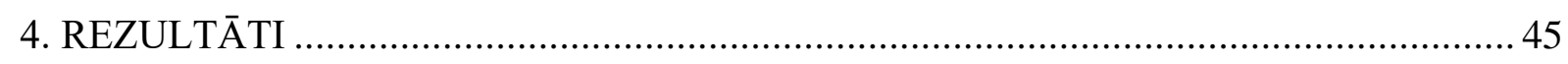

4.1. Pētījumā iekḷauto pacientu demogrāfiskie un slimību raksturojošie rādītāji............... 45

4.2. TML artrīta attīstību ietekmējošie faktori ....................................................... 46

4.2.1. Demogrāfiskie, slimību raksturojošie klīniskie un laboratoriskie rādītāji ......... 46

4.2.2. TML artrīta attīstību ietekmējošās HLA II klases riska un

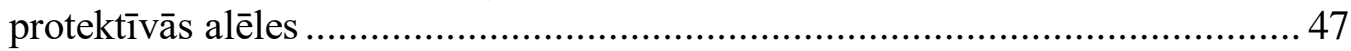

4.3. Subjektīvie un objektīvie klīniskie TML artrīta simptomi un

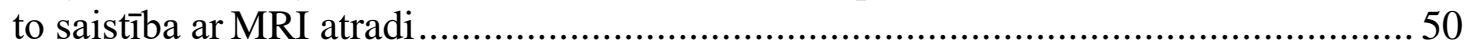

4.4. MRI TML atrade kopējā pacientu grupā, simptomātiskiem un

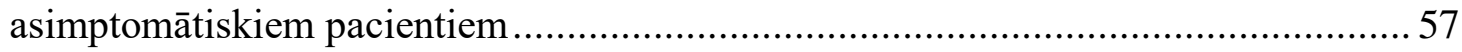

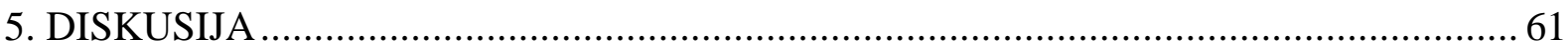

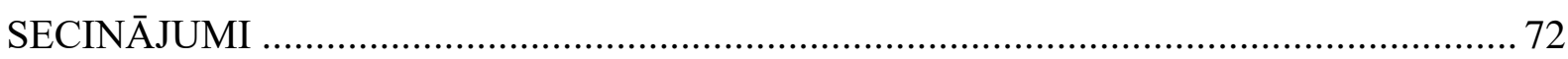

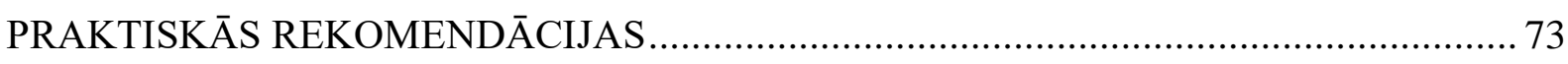

PERSPEKTĪVIE TURPMĀKO PĒTİJUMU VIRZIENI .................................................. 74

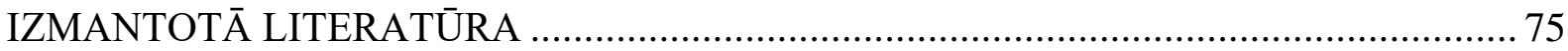

Publikācijas un prezentācijas par promocijas darba tēmu.................................................... 81

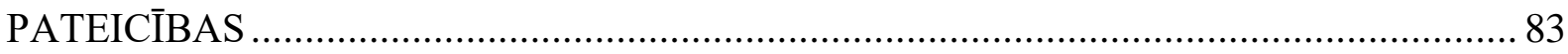

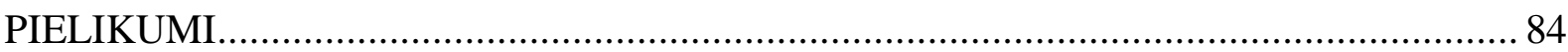




\section{DARBĀ LIETOTIE SAĪSINĀJUMI}

ACR

ASV

ANA

BKUS

CHAQ

CI

CRP

DT

EGĀ

HLA

IFN gamma

IL

ILAR

i/a

JADAS-10

(vai 27 , vai 71 )

Amerikas Reimatologu asociācija (American College of Rheumatology)

Amerikas Savienotās Valstis

antinukleārās antivielas

Bērnu klīniskā universitātes slimnīca

bērnu veselības aptaujas lapa (Childhood Health Assessment Quietionnaire)

ticamības intervāls (confidence interval)

C-reaktīvais proteīns

datortomogrāfija

eritrocītu grimšanas ātrums

cilvēka leikocītu antigēni (human leukocyte antigen)

interferons gamma

interleikīni

Starptautiskā reimatologu asociāciju līga

(International League of Associations for Rheumatology)

intraartikulāra

juvenilā artrīta slimības aktivitātes skala

(Juvenile Arthritis Disease Activity Score),

skaitlis norāda uz izmeklēto locītavu skaitu

JIA juvenils idiopātisks artrīts

\section{KIIS}

laboratorija Klīniskās imunoloǵijas un imunoǵenētikas starpkatedru laboratorija

Maks. maksimālā vērtība

$\mathrm{mg} / \mathrm{L} \quad$ miligrami litrā

MHC

galvenais audu saderības komplekss (major histocompatibility complex)

Min. minimālā vērtība

$\mathrm{mm} / \mathrm{h} \quad$ milimetri stundā

MRI

magnētiskās rezonanses izmeklējums

MRP8/14 ar mieloīdām šūnām saistītie proteīni (myeloid related protein)

MTX metotreksāts

NSPL nesteroīdie pretiekaisuma līdzekḷi

OR izredžu attiecība (odds ratio)

p statistiskā nozīmīguma (būtiskuma) līmenis jeb

pirmā veida kḷūdas varbūtība (probability) 


\begin{tabular}{|c|c|}
\hline pGALS & $\begin{array}{l}\text { pediatriskais gaitas, roku, kāju un muguras skrīnings } \\
\text { (paediatric Gait Arms Legs and Spine) }\end{array}$ \\
\hline RF & reimatoīdais faktors \\
\hline RSU & Rīgas Stradiṇa universitāte \\
\hline RT-PCR & $\begin{array}{l}\text { reālā laika polimerāžu k̦ēžu reakcijas metode } \\
\text { (mutliprimer real time polimerase chain reaction) }\end{array}$ \\
\hline Rtg & rentgenogrāfija \\
\hline $\mathrm{SN}$ & standartnovirze \\
\hline TNF & tumora nekrozes faktors \\
\hline TML & temporomandibulārās locītavas \\
\hline USG & ultrasonogrāfija \\
\hline VAS & vizuālo analogu skala \\
\hline$k$ & kappa koeficients \\
\hline$\chi^{2}$ & hī kvadrātā \\
\hline
\end{tabular}




\section{IEVADS}

\subsection{Darba zinātniskā aktualitāte}

Temporomandibulāro locītavu (TML) artrīts juvenila idiopātiska artrīta (JIA) slimniekiem ir problēma, kam pēdējos vairāk nekā piecus gadus Eiropā un ASV ir pievērsta īpaša uzmanība. Ik gadu kopš 2010. gada tiek organizētas starptautiskas konferences ar reimatologu, ortodontu, stomatologu, radiologu piedalīšanos, kas veltītas TML artrītam JIA slimniekiem. Šo aktivitāšu un pētîjumu mērḳis ir slimniekiem ar juvenilu idiopātisku artrītu novērst būtisku funkcionālu un morfologisko kraniofaciālā rajona izmainu attīstīšanos.

JIA ir biežākā reimatologiiskā slimība bērnu vecumā, kuras galvenā pazīme ir hronisks artrīts, kas sācies līdz 16 gadu vecumam; tas ilgst vairāk par 6 nedēḷām un, kā liecina nosaukums, ir idiopātisks - nezināmas etiologiijas (Cassidy et al., 2011; Ravelli, Martini, 2007).

JIA gadījumā iekaisums var attīstīties jebkurā locītavā, tai skaitā arī TML. Šo locītavu bojājumu nosaka anatomiskās īpatnības - apakšžokḷa kaula augšanas centrs atrodas tieši zem skrimšḷa, kas izklāj locītavu, tādēl iekaisuma process agrīni ietekmē apakšžokḷa augšanu (Ringold et al., 2009; Fam et al., 2006; Cassidy et al., 2011). TML artrīts ar aktīva iekaisuma pazīmēm vai locītavās ieejošo struktūru izmaiṇām, pēc literatūras datiem, sastopams līdz 87\% JIA slimnieku un bieži tiek diagnosticēts vēlīni, kad jau tiek konstatēts locìtavās ieejošo struktūru neatgriezenisks bojājums (Arabshahi et al., 2006; Küseler et al., 1998).

JIA slimniekiem, kuriem ir iekaisums TML, ir dentofaciālās attīstības traucējumu risks. Šie traucējumi neārstēti var komplicēties ar patologíski izmainītām kraniomandibulārām funkcijām un tādiem dentofaciāliem morfologiskiem traucējumiem kā mikrognātija, retrognātija, sejas asimetrija, patologisks sakodiens, samazināts mutes atvērums (Perttiniemi et al., 2009; Fjeld et al., 2010). Šādas izmaiņas rada funkcionālas problēmas, piemēram, košḷāšanas procesā, verbālo un emocionālo izpausmju ierobežojumus, kā arī ievērojamus estētiskus defektus, kas savukārt nelabvēlīgi var ietekmēt bērna psihoemocionālo stāvokli. Temporomandibulāro locītavu funkciju traucējumi ir otrā biežākā hroniskā muskuloskeletālā patolog̣ija aiz muguras lejasdaḷas sāpēm (Ahmad, Schiffman, 2016).

Līdz šim ir pētīti dažādi faktori, kas ietekmē TML artrìta attīstību. Visbiežāk tas konstatēts JIA slimniekiem ar poliartikulāru un sistēmisku gaitu, tomēr TML artrīts var būt arī pirmā un vien̄igā slimības izpausme (Cassidy et al., 2011). Ir pētījumi, kas liecina, ka TML artrīta attīstība nav atkarīga no JIA apakštipa un ka tas var persistēt arī gadījumos, kad citās locītavās ir remisija (Stoll et al., 2012). Biežāk skartas TML ir konstatētas JIA slimniekiem ar 
pozitīvām antinukleārajām antivielām un reimatoīdo faktoru (Arabshahi et al., 2006). Ir pētītas HLA II klases alēles dažādu JIA tipu pacientiem un konstatēts, ka saslimšana ar noteikta tipa JIA var būt ǵenētiski predisponēta (Hollenbach et al., 2010). Tomēr līdz šim nav bijis pētījumu par HLA II klases alēēēm pacientiem ar JIA un TML artrītu.

Lai diagnosticētu TML artrītu, nepieciešams kombinēt dažādas metodes - gan klīniskas, gan radioloğiskas. Ir konstatēts, ka pacienta subjektīvās sūdzības un objektīvā klīniskā atrade bieži vien nekorelē ar MRI atradi, tomēr pēdējo gadu pētījumos ir konstatētas arī daudzas nepilnības, piemēram, nav izmantoti standartizēti un mērḳtiecīgi anamnēzes jautājumi, kā arī objektīvās izmeklēšanas metodika dažādos pētījumos bijusi ḷoti atšḳirīga. TML artrīta simptomi var būt sāpes apakšžokḷa kustību laikā, košḷājot cietāku barību, apakšžokḷa asimetrija, atverot muti, intraartikulāra krepitācija, klikšķēšana, greizais kakls, tomēr tiem ir augsta specifitāte, bet zema sensitivitāte (Cannizzaro et al., 2011; Twilt et al., 2004). Izmantojot tikai klīniskos simptomus, iespējama arī hiperdiagnostika (Koos et al., 2014).

No radioloǵiskajiem izmeklējumiem informatīvākā metode TML artrīta diagnostikā salīdzinājumā ar ultrasonogrāfiju un konvencionālo rentgenogrammu ir magnētiskās rezonanses izmeklējums (MRI) ar kontrastvielu (Müller et al., 2009). Ar MRI metodi var izvērtēt kaulu, locītavas disku un fibrozo skrimsli, kā arī izvērtēt intrartikulārā šḳidruma daudzumu un pastiprinātu sinovija kontrastēšanos. MRI metode dod iespēju agrīni diagnosticēt TML artrītu arī asimptomātiskiem pacientiem, līdz ar to ir iespējams uzsākt agrīnu ārstēšanu (Argyropoulou et al., 2009; Pedersen et al., 2008; Weiss et al., 2008). Tomēr MRI metode ir salīdzinoši dārga, tāpēc pagaidām Latvijā, kā arī citviet Eiropā šo izmeklējumu nav iespējams veikt visiem JIA slimniekiem, turklāt tas būtu jāveic atkārtoti dažādos slimības posmos - gan iniciāli, gan arī dinamikā.

Būtu nepieciešams noskaidrot pacientu grupu, kuriem pēc noteiktiem klīniskiem un laboratoriskiem kritērijiem indicēts MRI izmeklējums, jo sagaidāmais rezultāts var noteikt terapijas taktikas maiņu.

Agrīna TML artrīta diagnostika nosaka terapijas taktiku. Paralēli sistēmiskai terapijai ar slimību modificējošiem pretreimatiskiem līdzekḷiem (gan sintētiskiem, gan bioloğiskiem) tiek izmantota lokālā terapija ar intraartikulārām (i/a) sterō̄du ievadēm un atslogojošām zobu kapēm (Ringold et al., 2008; Stoll et al., 2012). Sistēmiska terapija tiek nozīmēta atbilstoši Latvijā apstiprinātām JIA ārstēšanas vadlīnijām atkarībā no slimības tipa, nelabvēlīgas prognozes faktoriem un slimības aktivitātes (Juvenila idiopātiska artrīta klīniskās vadlīnijas, 2016). JIA ārstēšanā kā pirmās rindas medikaments tiek lietots metotreksāts (MTX), bet gadījumos, kad šī terapija nav pietiekami efektîva, tiek lietoti bioloǵiskie medikamenti: 
etanerceptum, adalimumabum, abataceptum, tocilizumabum u. c. Lokālā terapija, ievadot intraartikulārus glikokortikosterō̄dus, tiek lietota gadījumos, kad TML saglabājas aktīvs iekaisums, jo sistēmiska terapija ar nesterō̄diem pretiekaisuma līdzekḷliem, slimību modificējošiem medikamentiem, reizēm arī glikokortikoīdiem sistēmiski nepalīdz, kā arī gadījumos, kad MRI redzamas izteiktas aktīva iekaisuma pazīmes un ir pacienta dzīves kvalitāti ierobežojoši simptomi.

Agrīna sistēmiska un lokāla terapija ir svarīga, lai saglabātu locītavu kustīgumu un dotu iespēju bojātajiem apakšžokḷa kondiḷiem reǵenerēt. Ir pētījumi, kas liecina, ka intraartikulāra steroīdu ievade ir droša un efektīva gan sāpju mazināšanai, gan arī TML funkciju uzlabošanai (Arabshahi et al., 2005). Šobrīd vēl nav starptautisku vadlīniju, kādos gadījumos intraartikulāra ievade būtu veicama obligāti. Iespējams, ka dậā gadījumu pietiek ar sistēmisku terapiju, tomēr, lai to izvērtētu, nepieciešama rūpīga pacienta novērošana dinamikā, tostarp pēc iespējas detalizētāka un objektīvāka TML izvērtēšana.

Lai veiksmīgi aprūpētu šos pacientus, nepieciešams noteikt faktorus, kas ietekmē TML artrīta attīstību, kā arī to, kādi subjektīvi un objektīvi klīniskie simptomi biežāk ir saistīti ar TML artrītu un kuros gadījumos nepieciešama pēc iespējas agrīnāka diagnostika ar MRI, lai izvēlētos piemērotāko ārstēšanas taktiku. Tādējādi būtu iespējams novērst TML artrīta radītos kraniomandibulāros funkciju un morfolog̣iskos traucējumus.

\subsection{Darba hipotēzes, mērḳis, uzdevumi}

\section{Darba hipotēzes:}

1. Demogrāfiskie, klīniskie, laboratoriskie un ǵenētiskie faktori ietekmē TML artrīta attīstības risku JIA slimniekiem.

2. Subjektīvie un objektīvie TML artrīta klīniskie simptomi ir saistīti ar MRI radiolog̣isko atradi.

Darba mērḳis: noskaidrot TML artrīta attīstību ietekmējošos demogrāfiskos, slimību raksturojošos klīniskos, laboratoriskos un ǵenētiskos faktorus, kā arī klīniskos (subjektīvos un objektīvos) un radioloǵiskos simptomus un to savstarpējo saistību bērniem ar juvenilu idiopātisku artrītu.

\section{Darba uzdevumi:}

1. Noskaidrot pētāmās pacientu grupas demogrāfiskos un slimību raksturojošos klīniskos un laboratoriskos rādītājus. 
2. Izpētīt TML artrīta attīstību ietekmējošos faktorus, salīdzinot demogrāfiskos, slimību raksturojošos klīniskos, laboratoriskos rādītājus, HLA II klases alēḷu genotipēšanas rezultātus pacientu grupās ar pozitīvu MRI atradi (MRI+), t. i., ar aktīva un/vai hroniska iekaisuma pazīmēm un negatīvu MRI atradi (MRI-).

3. Noskaidrot subjektīvo un objektīvo TML artrīta simptomu saistību ar TML MRI radioloǵgisko atradi, salīdzinot $\mathrm{MRI}+$ un MRI- grupu, kā arī atkarībā no aktīva un/vai hroniskai iekaisuma pazīmēm MRI.

4. Izvērtēt MRI rezultātu atkarībā no aktīva iekaisuma pazīmēm un/vai neatgriezeniskām strukturālām izmaiņām JIA slimniekiem ar TML artrīta subjektīviem un/vai objektīviem simptomiem (simptomātiskiem pacientiem) un pacientiem, kam nav simptomu no TML puses (asimptomātiskiem pacientiem).

\subsection{Pētījuma zinātniskā novitāte}

1. Pirmo reizi Latvijā tiek pētîti temporomandibulāro locītavu artrīta attīstîbu ietekmējošie faktori juvenila idiopātiska artrīta slimniekiem, tādējādi pievēršot uzmanību anatomiski unikāli veidotas un funkcionāli nozīmīgas locītavas bojājumam un tā savlaicīgai diagnostikai.

2. HLA II klases alēles slimniekiem ar JIA un TML artrītu līdz šim nav pētītas, tādejādi pêtījuma rezultāti sniedz ieguldījumu JIA patoǵenēzes un klasifikācijas izpētē, kā arī personalizētās medicīnas attīstībā.

\subsection{Pētījuma praktiskais pielietojums}

Ṇemot vērā TML artrīta attīstību ietekmējošos demogrāfiskos, slimību raksturojošos, klīniskos un laboratoriskos faktorus un HLA II klases riska un protektīvās alēles, iespējams noteikt tos JIA slimniekus, kuriem nepieciešama agrīna diagnostika ar MRI metodi, kas savukārt nosaka turpmāko terapijas taktiku, lai novērstu iespējamu neatgriezenisku locītavu bojājumu. Pamatojoties uz pētījuma rezultātiem, izveidotas praktiskās rekomendācijas bērnu reimatologiem TML artrīta diagnostikai.

Pētījums ir veicinājis un turpina attīstīt interdisciplināru bērnu reimatologu, radiologu, ortodontu un ǵenētikas speciālistu sadarbību un komandas izveidi juvenila idiopātiska artrīta slimnieku aprūpē. 


\section{LITERATŪRAS APSKATS}

\subsection{JIA un TML artrīts}

\subsubsection{JIA - definīcija, etioloğija, patoǵenēze, klasifikācija un klīniskā aina}

Juvenils idiopātisks artrīts (JIA) ir nezināmas etioloǵijas heterogēnu artrītu grupa (Cassidy et al., 2011). Saskaņā ar Starptautiskās reimatologu asociāciju līgas (ILAR) kritērijiem JIA jēdziens ietver slimību grupu, kam ir kopīga iezīme - tas ir artrīts, kas sākas līdz 16 gadu vecumam, ir ilgāks par 6 nedēḷām un tam nav zināma etiologija. JIA ir biežākā autoimūnā iekaisuma slimība bērniem ar incidenci 1-20/100 000 bērnu (Cassidy et al., 2011).

Kā jau minēts definīcijā, JIA etiologija nav noskaidrota un ir multifaktoriāla. No ǵenētiskajiem faktoriem spēcīgākā asociācija dažādiem JIA tipiem atrasta ar HLA gēniem (human leukocyte antigen) jeb cilvēka leikocītu antigēniem, kas lokalizēti 6. hromosomā (Hinks et al., 2013). Ir konstatēts, ka JIA slimnieku gimenēs ir augstāka dažādu citu hronisku iekaisuma slimību un autoimūnu slimību prevalence. Pilna genoma sekvenēšanas rezultāti JIA slimniekiem liecina par multipliem šīs slimības ǵenētiskajiem variantiem (Wong et al., 2017). Ģenētiskā predispozīcija gan ir tikai viens no faktoriem, uz ko norāda ǵimeṇu pētījumi pārmantošanas gadījumi pārsvarā novērojami tikai atsevišķu JIA tipu, piemēram, artrīta ar entezītu un psoriātiska artrīta, gadījumā. Ir pētīta vides faktoru ietekme, piemēram, barošana ar krūti (dati ir pretrun̄̄gi), mātes smēķēšana grūtniecības laikā, hormonāli faktori, infekcijas un imunizācija, arī psiholoğiski faktori (Cassidy et al., 2011).

Patoǵenētiski būtiskākais ir hronisks iekaisums ar iedzimtās un iegūtās imunitātes traucējumiem - novēro T šūnu disregulāciju, citokīnu (TNF alfa, IL-1, IL-17, IL-6, IFNgamma, MRP8/14) pārprodukciju. Sinovijā pastiprinās vaskularizācija, tas kḷūst biezāks, infiltrēts ar T šūnām, makrofāgiem, dendrītiskām šūnām, B šūnām un izdala eksudātu, kas tālāk veicina locītavas skrimšḷa un kaulu bojājumu (Cassidy et al., 2011).

Pēc ILAR klasifikācijas JIA ir septiņi tipi (2.1. tabula), kas atšķiras pēc skarto locītavu skaita, entezīta vai psoriāzes esamības un sistēmiskiem simptomiem. Kā redzams 2.1. tabulā, katram slimības tipam ir raksturīgs konkrēts saslimšanas vecums, ir arī dzimumu atšķirības, kā, piemēram, oligoartrīta gadījumā, kas biežāk sastopams pirmsskolas vecuma meitenēm un kam raksturīga uveīta pievienošanās un pozitīvas antinukleārās antivielas (Ravelli, Martini, 2007). 


\section{1. tabula}

ILAR klasifikācijai atbilstošo JIA apakštipu biežums, bērnu vecums slimības sākumā, sadalījums pēc dzimumiem*

\begin{tabular}{|c|c|c|c|}
\hline JIA apakštips & $\begin{array}{c}\text { Sastopamības } \\
\text { biežums, \% no visiem } \\
\text { JIA gadījumiem }\end{array}$ & $\begin{array}{l}\text { Vecums slimības } \\
\text { sākumā }\end{array}$ & $\begin{array}{c}\text { Dzimumu attiecība } \\
\text { (M - meitenes, } \\
\mathrm{Z} \text { - zēni) }\end{array}$ \\
\hline Sistēmisks artrīts & $4-17$ & Visu vecumu bērni & $\mathrm{M}=\mathrm{Z}$ \\
\hline $\begin{array}{l}\text { Oligoartrìts: } \\
\text { persistējošs un } \\
\text { progresējošs }\end{array}$ & $27-56$ & $\begin{array}{l}\text { Agrīnā bērnu vecumā, } \\
\text { biežāk } 2-4 \text { gadu vecumā }\end{array}$ & $M \gg>Z$ \\
\hline Seropozitīvs artrīts & $2-7$ & $\begin{array}{c}\text { Vēlīnā bērnu vecumā, } \\
\text { pusaudžiem }\end{array}$ & $M \gg \mathrm{Z}$ \\
\hline Seronegatīvs artrīts & $11-28$ & $\begin{array}{c}\text { Divfāzisks sadalījums: } \\
\text { agrīnā vecumā } \\
\text { saslimstības maksimums } \\
\text { ir 2-4 gadu vecumā, vēlāk } \\
\text { 6-12 gadu vecumā } \\
\end{array}$ & $M \gg \mathrm{Z}$ \\
\hline $\begin{array}{l}\text { Ar entezìtu saistīts } \\
\text { artrìts }\end{array}$ & $3-11$ & $\begin{array}{l}\text { Vēlīnā bērnu vecumā, } \\
\text { pusaudžiem }\end{array}$ & $\mathrm{Z}>>\mathrm{M}$ \\
\hline Psoriātisks artrīts & $2-11$ & $\begin{array}{c}\text { Divfāzisks sadalījums: } \\
\text { agrīnā vecumā } \\
\text { saslimstības maksimums } \\
\text { ir 2-4 gadu vecumā, vēlāk } \\
\text { 9-11 gadu vecumā }\end{array}$ & $\mathrm{M}>\mathrm{Z}$ \\
\hline Nediferencēts artrīts & $11-21$ & $\begin{array}{l}\text { Nav raksturīgs konkrētai } \\
\text { vecuma grupai. }\end{array}$ & $\begin{array}{c}\text { Nav būtisku dzimuma } \\
\text { atškirīibu }\end{array}$ \\
\hline
\end{tabular}

* Adaptēts no Ravelli, Martini, 2007.

Par šo klasifikāciju notiek diskusijas, īpaši par sistēmisku artrītu, kas pēc patoǵenēzes un klīniskās ainas vairāk atbilst autoiekaisīgai slimībai. Problemātiski ir arī ar entezìtu asociētā artrīta un seronegatīvu spondiloartropātiju jēdzieni. Ir priekšlikumi klasifikācijā ṇemt vērā imunologiskos marķierus, piemēram, pozitīvas ANA (Petty et al., 2016). Katram no septiņiem slimības tipiem ir īpatnības, kas saistītas ar biežāk iesaistītajām locītavām. Piemēram, ar entezītu asociētā artrīta gadījumā biežāk ir skartas apakšējo ekstremitāšu locītavas, turklāt asimetriski (Petty et al., 2016). Lai attīstītu pilnvērtīgu klasifikāciju, ir būtiski izprast dažādos locītavu iesaistes modeḷus, kā arī citas katra tipa īpatnības, tostarp laboratoriskās. N̦emot vērā arvien pieaugošo informāciju par g̊enētisko JIA predispozīciju, iespējams, klasifikācijā ar laiku tiks ņemti vērā arī genētisko izmeklējumu rezultāti, piemēram, HLA II klases alēles (Hollenbach et al., 2010).

JIA klīniskā aina dažādu iepriekš minēto tipu gadījumā atšķiras. Visiem tipiem ir raksturīgas konstitucionālās pazīmes, arī nogurums, anoreksija, svara zudums, augšanas aizture. Artrīta pazīmes ne vienmēr ir sāpes locītavās, bet bieži vien uz to var norādīt netiešas pazīmes - locītavu stīvums, nevēlēšanās kustēties, klibošana. No iekaisuma pazīmēm biežāk 
novēro pietūkumu, sāpes, hiperēmiju, kustību ierobežojumus, retāk ir eritēma. Temporomandibulārās locītavas ir vienas no tām (līdzịgi kā sakroileālās, intervertebrālās), kurās no iekaisuma pazīmēm pietūkums, lokāla hiperēmija vai eritēma vērojama reti, tādējādi iekaisumu grūtāk atpazīt. JIA komplikācijas ir vispārēji un lokāli augšanas traucējumi, locītavu spraugas sašaurināšanās vai pat slēgšanās, kas izpaužas ar funkciju traucējumiem un izraisa invalidizāciju (Petty et al., 2016., Ravelli, Martini, 2007).

\subsubsection{TML anatomiskās īpatnības}

Temporomandibulārā locītava ir sinoviāla locītava starp deniṇu kaula bedrīti (fossa mandibularis) un apakšžokḷa kaula kondiliem. Abām locītavām strādājot vienlaikus, tiek veiktas kustības uz augšu un uz leju, protrakcija, retrakcija, kustība no sāna uz sānu. Tādējādi iespējams nodrošināt tādas funkcijas kā košḷāšana, rīšana, runa. Unikāla TML īpatnība, kas atškiir to no citām sinoviālajām locītavām, ir locītavas disks, ko veido fibrozais skrimslis (citās sinoviālajās locītavās tas ir hialīnais skrimslis), kas sadala locītavu divos nodalījumos apakšējā un augšējā, no kuriem katram ir sava funkcija, veicot dažādas kustības (2.1. att.). Disks darbojas kā amortizētājs košḷāšanas kustību laikā un stabilizē locītavu. Locītavu ietver kapsula, kam ir ārējais fibrozais un iekšējais sinoviālais slānis, tā ir ḷoti elastīga un atḷauj veikt dažādas kustības. Jāṇem vērā, ka abas locītavas darbojas sinhroni, jo ir savienotas ar vienu apakšžokḷa kaulu (Alomar et al., 2007; David, Elavarasi, 2016; Morton et al., 2011; Fam et al., 2006).

Anatomiskās un histolog̣iskās īpatnības nosaka TML bojājuma raksturu - skrimslis, kas klāj apakšžokḷa kaula kondiḷus, funkcionē ne tikai kā šoka absorbētājs, bet arī kā augšanas centrs, tādēl iekaisums agrīni ietekmē apakšžokḷa augšanu. Garajos kaulos šīs funkcijas nodrošina divi dažādi skrimšḷi - locītavu izklājošais un augšanas zonas skrimslis, savukārt apakšžokḷa kondiḷus klājošais skrimslis pilda abas šīs funkcijas vienlaikus (Cassidy et al., 2011; Fam et al., 2006; Mizoguchi, Toriya, Nakao, 2013; Peltomäki et al., 2015; Ringold et al., 2009). 

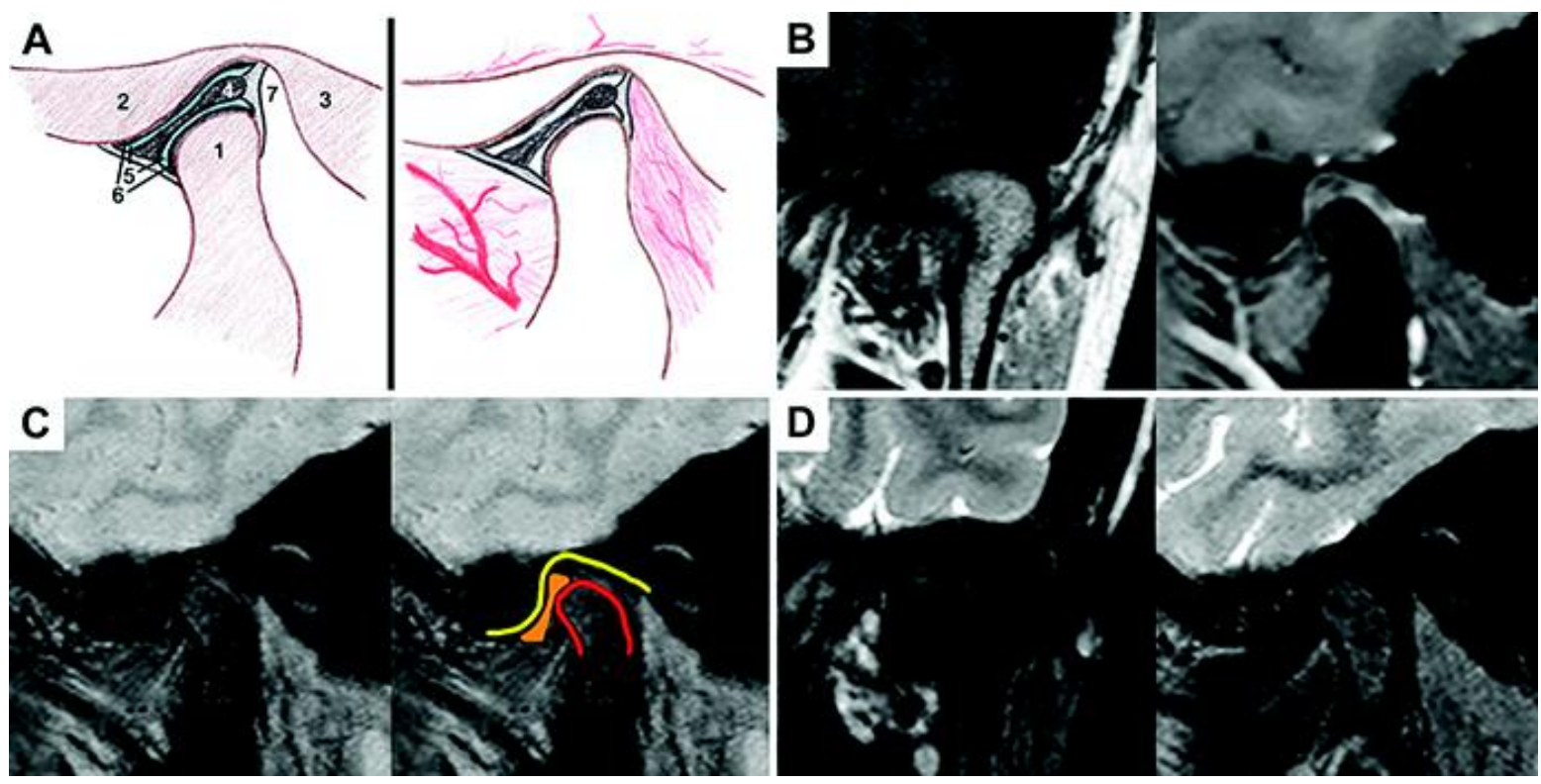

\section{1. attēls. Temporomandibulāro locītavu anatomija - shematiski un MRI attēlos}

(Vaid et al., 2014):

A - normālas TML anatomija sagitāli: 1 - apakšžokḷa kondilis; 2 - deninu kaula locītavas virsma; 3 - deniņu kaula mastoidālā daḷa; 4 - locītavas disks; 5 - augšējais un apakšējais locītavas nodalījums; 6 - augšējais un apakšējais locītavas skrimslis; 7 - bilaminārā zona. Labajā pusē ar sārtu iekrāsotas normālas kontrastvielas uzkrāšanās zonas;

B - MRI attēli koronāri (pa kreisi) T1 un sagitāli (pa labi) T1 ar normālu ieapaḷu kondiḷu formu, locītavas spraugu, normālu sinoviālo kontrastēšanos, kaula smadzeṇu signālu;

C - sagitāli attēli demonstrē normālus kondiḷus (apvilkti ar sarkanu), disku (oranžs), locītavas virsmu (dzeltena);

D - koronāri (pa kreisi), sagitāli (pa labi) attēli ar normālu TML struktūru

\subsubsection{TML artrīta izplatība JIA slimniekiem}

TML iesaistīšanās - ar to saprot akūta iekaisuma pazīmes vai locītavās ieejošo struktūru izmaiṇas, kas var veidoties, nediagnosticējot un neārstējot akūtās izmaiṇas - pēc literatūras datiem sastopama līdz 87\% JIA slimnieku un bieži tiek diagnosticēta vēlīni, kad tiek konstatēts locītavās ieejošo struktūru neatgriezenisks bojājums (Argyropoulou et al., 2009; Ringold et al., 2009; Küseler et al., 1998). Millera un kolēǵu pētījumā tika apsekoti 30 JIA slimnieki un konstatēts, ka 63\% pacientu ir TML artrīta pazīmes, izmeklējot ar MRI (Müller et al., 2009). Veiss un kolēgi apsekoja 32 pacientus, kuriem pirmreizēji bija diagnosticēts JIA, un 75\% atrada aktīvas TML artrīta pazīmes, 69\% - hroniskas un 53\% - gan akūtas, gan hroniskas (Weiss et al., 2008). Kanizaro un kolēgi konstatēja, ka 38,6\% no 223 JIA slimniekiem vidēji 4,6 gadus no slimības sākuma, balstoties uz klīnisko un/vai radioloǵisko izmeklēšanu, tika apstiprināts TML artrīts (Cannizzaro et al., 2011).

Kristensens un kolẹgi literatūras pārskatā par TML pētījumiem JIA slimniekiem konstatējuši, ka, pamatojoties uz tiem, grūti spriest par TML artrīta izplatību, jo pārsvarā pētīti 
pacienti, par kuriem jau ir bijušas aizdomas par TML artrītu, balstoties uz kādiem subjektīviem vai objektīviem simptomiem, savukārt ir maz un nelieli pētījumi par pirmreizēji diagnosticētiem JIA gadījumiem, kuriem pētīta TML iesaistīšanās izplatība (Kristensen et al., 2016).

\subsubsection{TML artrīta ietekme uz kraniofaciālā reǵiona attīstību, morfoloğiju un funkcijām}

Kraniofaciālā rajona augšanai ir raksturīgas dažādas attīstības pakāpes - infantilā, juvenilā, pubertālā, postpubertālā un pieaugušo attīstības pakāpe. Normāli attīstoties, augšžoklis un apakšžoklis pakāpeniski pārvietojas virzienā uz priekšu un uz leju attiecībā pret galvaskausa pamatni, savukārt JIA slimniekiem novēro retrognatisku, mikrognatisku apakšžokli un tā mugurēju rotāciju attiecībā pret augšžokli un galvaskausa pamatni. N̦emot vērā, ka apakšžoklis aug no skrimšḷa, kas izklāj TML, iekaisuma process šajā locìtavā var būtiski izmainīt normālu augšanas procesu (Peltomäki et al., 2015). Septiṇdesmit procentiem JIA slimnieku ar TML iesaisti novēro kādus no kraniofaciālās augšanas traucējumiem, sākot ar nelielām erozijām līdz pat smagām apakšžokḷa kondiḷu deformācijām (Arvidsson et al, 2010). Šīs pazīmes visizteiktāk izpaužas 9-12 gadu vecumā, kad notiek straujāka augšana (Carvalho et al, 2012). Apakšžokḷa osifikāciju var ietekmēt dažādi citi ar artrītu saistīti faktori, piemēram, sāpes TML rajonā var traucēt normālu košanas muskuḷu attīstību, kas var izraisīt 1̄sāku apakšžokḷa zaru attīstību (Twilt et al., 2006).

Pirmo reizi hroniska artrīta ietekmi uz sejas attīstību aprakstīja Diamantbergers 1890. gadā, respektīvi, nepietiekami attīstās apakšžoklis, kas rada iespaidu par putnam līdzīgu seju (Diamantberger, 1890), sk. 2.2. att.

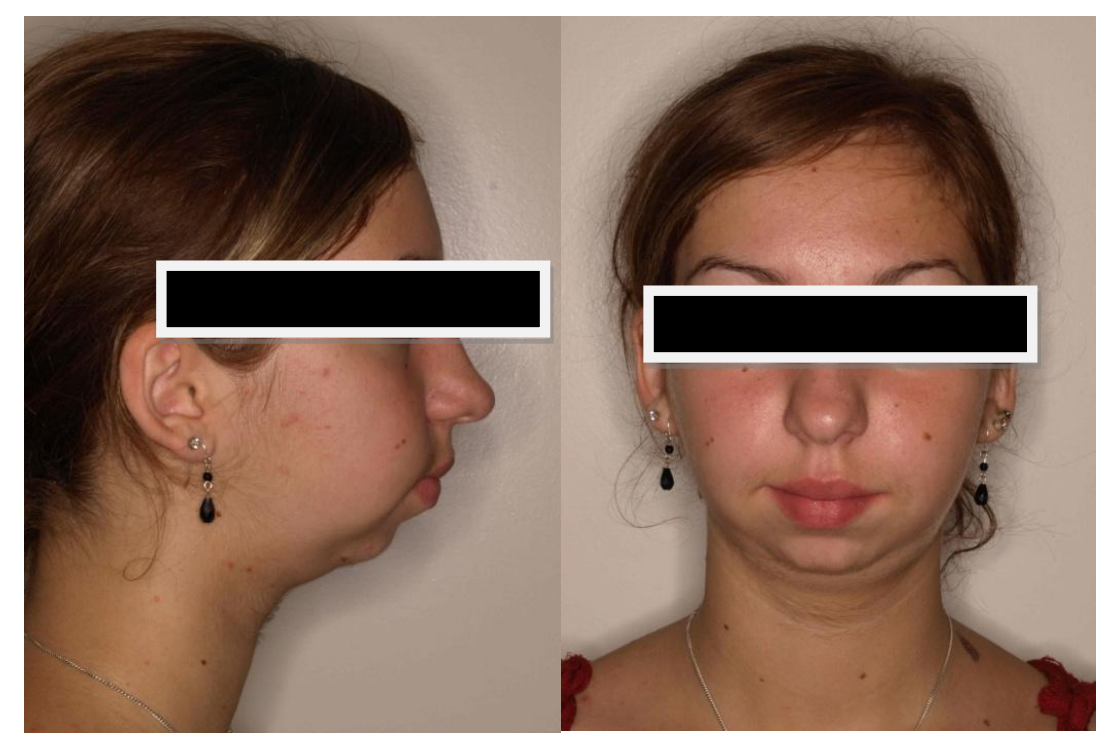

2.2. attēls. Paciente ar JIA, kurai vērojamas TML artrīta radītās sekas - "putna seja" ar mikrognātiju un retrognātiju (attēls no autores personiskā arhīva) 
Somu pētījumā (Rönning et al., 1994) 67 JIA slimnieki tika izvērtēti ar cefalometrisku mērījumu palīdzību, lai noteiktu, vai tiem ir tā saucamā "putna sejas" deformācija. Deviņpadsmit pacientiem mērījumi atbilda šai deformācijai: tika konstatētas izmaiņas apakšžokḷa un augšžokḷa mērījumos, piemēram, kopējais sejas augstums bija mazāks, tika novērots, ka ir samazināta augšžokḷa vertikālā attīstība. Šie faktori savukārt ietekmēja arī dentoalveolāro attīstību, jo normālai attīstībai trūkst vietas. Minētie pētnieki uzsver stomatologu lomu TML artrīta diagnostikā, kas nenoliedzami apstiprinās arī praksē.

JIA slimniekiem ar TML bojājumu ir dentofaciālās attīstības traucējumu risks, jo neārstēti bojājumi var patologiski izmainīt kraniomandibulārās funkcijas un komplicēties ar dentofaciāliem morfoğiskiem traucējumiem - mikrognātiju, retrognātiju, sejas asimetriju, patologisisku (vạ̣eju) sakodienu, samazinātu mutes atvērumu (Twilt et al., 2006; Perttiniemi et al., 2009; Fjeld et al., 2010; Hsieh et al., 2016). Tviltas un kolēgu pētījumā, izvērtējot JIA slimniekus neatkarīgi no TML artrīta diagnozes, retrognātija tika konstatēta 57/87 (67\%) pacientu, savukārt apakšžokḷa asimetrija bija 23/85 (27\%) pacientu. Pacientiem ar diagnosticētu TML iesaistǐšanos retrognātija bija biežāk nekā tiem, kam nebija TML simptomu - attiecīgi 82\% un 55\% gadījumu (Twilt et al., 2006).

2009. gadā tika publicēts pētījums par 60 JIA slimniekiem, kuri tika izvērtēti 29 gadus pēc pirmās izmeklēšanas, kas tika veikta laikā no 1976. līdz 1979. gadam. Tika vērtēta kraniofaciālā morfologija ar uzsvaru uz apakšžokḷa izmēru un novietojumu. Šiem pacientiem veica laterālos cefalogrāfiskos Rtg uzṇēmumus, CT un MRI. Sagitāli kraniofaciāli augšanas traucējumi tika novēroti 57\%, mikrognātija 27\% pacientu (12 pacientiem). Mikrognātija tika novērota vien̄̄gi bilaterāla TML artrīta gadījumā. Vidējais saslimšanas vecums ar JIA šiem 12 pacientiem ar mikrognātiju bija 4,9 gadi (Arvidsson et al., 2010). Pusei pacientu bez kraniofaciāliem augšanas traucējumiem bija temporomandibulāro locītavu iesaiste procesā jau no 12 gadu vecuma, kas nozīmē, ka TML artrīts ne vienmēr rezultējas ar augšanas traucējumiem, kas, iespējams, ir saistīts ar jaunākajām JIA ārstēšanas metodēm (Arvidsson et al., 2010). Ir novērots, ka TML iespējams remodelācijas process, t. i., kondiḷu morfologijas normalizācija (Arvidsson et al., 2009).

Resniks un kolēg̣i pētīja pieaugušos, kuriem anamnēzē bija JIA neatkarīgi no tā, vai TML iesaiste iepriekš bija konstatēta vai ne. No 21 pētījumā iesaistītā pacienta $62 \%$ TML rajonā tika konstatētas sāpes, 43\% bija TML funkcionāli ierobežojumi, 76\% novēroja apakšējās sejas daḷas asimetriju (Resnick et al., 2016).

Ir konstatēts, ka dažādi faktori, piemēram, slimības ilgums, tips, aktivitāte, iesaistīto locītavu daudzums, ietekmē radiologiski konstatējamās TML izmaiņas (Pedersen et al., 2001). Fjelds un kolēgi salīdzināja JIA slimnieku laterālās cefalogrammas 6, 9, 12 un 35 gadu 
vecumā ar veselu indivīdu parametriem un konstatēja, ka 6 un 9 gadu vecumā rezultāti pacientu un kontroles grupās nozīmīgi neatšks̄īās, savukārt jau 12 gadu vecumā JIA slimniekiem novēroja apakšžokḷa retrognātisku novietojumu, kā arī mazāku apakšžokḷa zaru un korpusa garumu. Šìs izmaiņas vēl izteiktākas bija 35 gadu vecumā (Fjeld et al, 2009).

TML artrīts dz̄ives kvalitāti var ietekmēt arī ilgtermiṇā. Norvēǵu pētnieki 1976. gadā sākta prospektīva JIA slimnieku pētījuma ietvaros aptaujāja un izmeklēja 60 pacientus, kuru vidējais slimības ilgums bija 29,8 gadi; 47 no viņiem tika veikta temporomandibulāro locītavu MRI un DT; 70\% tika konstatēta TML iesaistīšanās, kas biežāk bija bilaterāla ar osteoartrīta pazīmēm vai vieglu līdz vidēju sinoviālu kontrastēšanos, kā arī locītavas diska izmaiņas (destrukcija, fragmentācija, samazināts biezums). No pacientiem, kam bija iesaistītas TML, 33 (67\%) pacienti atzīmēja sāpes TML vai košanas muskuḷu apvidū, savukārt 18 (55\%) pacientiem bija samazināts mutes atvērums (Arvidsson et al., 2010). Kā sekas TML artrīta radītām izmaiṇām jāmin arī miega apnoja (Paul et al., 2015).

\subsection{TML artrīta attīstību ietekmējošie faktori}

\subsubsection{Demogrāfiskie faktori}

Kanizaro un kolēǵu pētījumā dzimuma attiecība (zēni : meitenes) pacientiem ar JIA un TML artrītu bija 2,4 : 1, savukārt jaunāks vecums slimības diagnosticēšanas brīdī izrādījās kā TML artrīta riska faktors (Cannizzaro et al., 2011). Millera un kolēǵu pêtījumā tika konstatēts, ka lielāks risks TML artrītam ir tad, ja vecums diagnozes noteikšanas brīdī bijis lielāks par sešiem gadiem (Müller et al., 2009). Tvilta ar kolēgiem konstatējusi, ka TML bojājums retāk ir sastopams pacientiem ar seropozitīvu poliartrītu, ko viņi skaidroja ar vēlīnāku slimības sākumu (biežāk pusaudžu vecumā), tādējādi arī mazāku ietekmi uz apakšžokḷa kondiḷu augšanu (Twilt et al., 2008).

\subsubsection{JIA tips, slimības gaita}

Visbiežāk TML iesaistīšanās ir konstatēta JIA slimniekiem ar poliartikulāru un sistēmisku gaitu, bet TML artrīts var būt arī pirmā un vienīgā slimības izpausme (Cassidy et al., 2011, Scollozzi et al., 2005). Kanizaro pētījumā TML artrīts biežāk (61\% gadījumu) tika konstatēts pacientiem ar progresējošu oligoartrītu, kam sekoja pacienti ar seronegatīvu poliartrītu (52\%), psoriātisku JIA (50\%), sistēmisku (36\%), seropozitīvu poliartrītu un persistējošu oligoartrītu (33\%), un ar entezītu asociēto JIA (11\%) 
(Cannizzaro et al., 2011). Arvidsones pētījumā apakšžokḷa augšanas traucējumi un TML iesaistīšanās tika novērota visu JIA tipu slimniekiem, biežāk ar progresējošu oligoartrītu (28\%) un seronegatīvu poliartrītu (23\%) (Arvidsson et al., 2010). Savukārt Tvilta un kolēǵi secinājuši, ka TML iesaiste ir raksturīga pacientiem ar poliartikulāru slimības gaitu neatkarīgi no slimības tipa (Twilt et al., 2008). Argiropoulou un viṇa kolēǵu pētījumā secināts, ka sakarā ar to, ka straujāk noritošam kondiḷu bojājumam ir augstāks risks, TML MRI obligāti būtu jāveic pacientiem ar sistēmisko JIA, kā arī visiem, kuriem slimība sākusies pirms četru gadu vecuma (Argyropoulou et al., 2008). Mohameds un kolēǵi sistēmiska un poliartikulāra JIA gadījumos konstatēja izteiktāku sinoviālo kontrastēšanos, izsvīdumu locītavas dobumā un lielāku kopējo MRI pazīmju skaitu salīdzinājumā ar oligoartrīta slimniekiem (Mohammed et al., 2012).

Kanizaro un kolẹgi konstatēja, ka TML artrīta riska faktori ir lielāks aktīvo locītavu skaits, augšējo ekstremitāšu locītavu iesaiste, mugurkaula kakla daḷas iesaiste, poliartikulāra slimības gaita, kā arī ilgāka slimība (Cannizzaro et al., 2011). Svarīgi ir izvērtēt TML artrītu kontekstā ar procesa aktivitāti citās locītavās. Dati ir pretrunīgi, tomēr ir vērojama tendence, ka TML artrītu biežāk atrod tajos gadījumos, kad ir vērojama procesa aktivitāte arī citās locītavās. Vienā pētījumā no 48 pacientiem ar aktīvu TML artrītu 16 gadījumos (33\%) bija aktīvs artrīts arī citās locītavās, savukārt tikai 2 no 19 pacientiem (11\%) bez TML artrīta pazīmēm MRI bija aktīvs citu locītavu artrīts (Ma et al., 2015).

Izmeklējot ar USG metodi, Janks un kolēg̣i konstatēja, ka izteiktākas TML destrukcijas pazīmes ir pacientiem, kuriem procesā iesaistītas 5 un vairāk locītavas, savukārt pacientiem ar slimības ilgumu vairāk nekā 23 mēneši biežāk tika atrasta diska dislokācija un destruktīvas izmaiņas (Jank et al., 2007).

Izmeklējot 60 JIA slimniekus 29 gadu garumā vairākas reizes, Arvidsone un kolēgei konstatēja, ka patoloǵiskas izmaiņas TML būtiski pieaug, palielinoties pacienta vecumam, un rezultātā lielākajai daḷai JIA slimnieku attīstās kāds bojājums TML. Vairumam pacientu TML bojājumi tika konstatēti pirms 15. dzimšanas dienas (Arvidsson et al., 2009).

Ferazs un kolēgi savukārt pētīja atšķirības konusa staru datortomogrāfijas atradē pacientiem, kuriem kopš slimības diagnosticēšanas un ārstēšanas uzsākšanas bija pagājuši trīs gadi, salīdzinot ar tiem, kam tie bija vairāk nekā trīs gadi. Tika kontstatēts, ka, jo ilgāka slimība, jo izteiktāki ir TML traucējumi (muskuloskeletālas sāpes, diska translokācija, osteoartrīta pazīmes) neatkarīgi no ārstēšanas (Ferraz Junior et al., 2012).

Noskaidrots, ka tādi slimības gaitu un aktivitāti raksturojoši rādītāji kā CHAQ, ārsta vispārējā VAS, vecāku VAS par sāpēm un vispārējo labklājīību nekorelē ar TML artrīta atradi MRI (Müller et al., 2009). 
Nav konstatēts, ka uveīta esamība palielinātu TML artrīta risku (Cannizzaro et al., 2011).

\subsubsection{Laboratoriskie rādītāji}

Kanizaro un kolēǵu pētījumā 223 (39\% no kohortas) JIA slimniekiem ar TML artrītu tika konstatēts augstāks EGĀ slimības sākumā, salīdzinot ar JIA slimniekiem bez TML iekaisuma. Savukārt CRP slimības sākumā, kā arī vidējie CRP un EGĀ rādītāji slimības gaitā nebija saistīti ar augstāku TML artrīta risku (Cannizzaro et al., 2011). Stolls un kolēgi savukārt secināja, ka iekaisuma rādītājiem nav ietekmes uz TML artrīta attīstību (JIA slimnieki ar TML iekaisumu šajā pētījumā bija 187, 43\% no kohortas) (Stoll et al., 2012). Minētajos pētījums arī noskaidrots, ka RF un ANA nav saistīti ar augstāku TML iekaisuma risku. HLA B27 antigēns Kanizaro un kolēǵu pētījumā tika saistīts ar mazāku TML artrīta risku (Cannizzaro et al., 2011). Līdz šim nav pētîta citu HLA alēlu saistība ar TML artrītu.

No perspektīvajiem iekaisuma biomarḳieriem ir zināms, ka S100 proteīni, īpaši S100A8/9 (zināmi arī kā ar mielō̄dām šūnām saistītie proteīni) un S100A12, ir saistīti ar augstāku JIA slimības aktivitāti, tomēr līdz šim nav pētīti pacientiem ar JIA un TML artrītu (Holzinger et al., 2012).

\subsection{JIA un HLA II klases alēles}

Līdz šim nav veikti pētījumi par HLA II klases alēlēm slimniekiem ar JIA un TML artrītu, tomēr ir pētīta dažādu JIA apakštipu slimības gaitas saistība ar HLA II klases alēlēm. Pētījumi liecina, ka juvenila idiopātiska artrīta attīstību nosaka kompleksi ǵenētiski un vides faktori. Par ǵenētisko predispozīciju liecina gan dvīṇu, gan ǵimeņu pētījumi. Līdz šim ǵenētikas izpētē grūtības radījis tas, ka JIA nav viena slimība, bet gan heterogēna slimību grupa, un JIA apakštipu klasifikācija laika gaitā ir main̄̄jusies. Problēmas sagādā arī tas, ka atsevišķās grupās ir salīdzinoši maz pacientu. Kopumā ir pētīts gan JIA un galvenais audu saderības komplekss jeb MHC (major histocompatibility complex), gan arī citokīnu gēnu polimorfisms (Thomson \& Donn, 2002).

MHC atrodas 6. hromosomā un ietver vairāk nekā 200 gēnus, kas ir svarīgi imūnās sistēmas regulācijā. Arī cilvēka leikocītu antigēnus kodējošie gēni (human leukocyte antigen, HLA) ir atrodami MHC rajonā. Tie ir ārkārtīgi polimorfi un tiek saistīti ar dažādām 
autoimūnām slimībām, piemēram, reimatōido artrītu, celiakiju, 1. tipa cukura diabētu u. c. (Hersh \& Prahalad, 2015).

Pirmoreiz par HLA saistību ar JIA tika ziņots 1979. gadā (Stastny \& Fink, 1979). Līdzšinējie pētījumi liecina, ka visciešākā saistība ir tieši ar HLA II klases alēlēm, mazāk ar HLA I klases gēniem. Analizējot HLA genotipēšanas rezultātus, jāṇem vērā, ka dažādās etniskās grupās šie dati atšķiras, tomēr ir arī konstantas HLA asociācijas ar JIA tipiem, kas ir līdzịgas dažādās populācijās. Vispārliecinošākā ir saistība ar DRB1, DQA1, DQB1 un DPB1 alēlēm (Runstadler et al., 2003). HLA alēes DRB1:01, DRB1:08, DRB1:11, DRB1:13, DPB1:02 ir saistītas ar oligoartikulāru JIA, savukārt DRB1*04 un DRB1*07 šiem pacientiem sastop retāk, tādēl tām, iespējams, ir protektīva nozīme (Vicario et al., 1990). Hollenbahs un kolēǵi savukārt salīdzinoši lielā pētījumā ar 820 JIA slimniekiem konstatēja, ka HLA DRB1:11:03/11:04 biežāk novēro pacientiem ar oligoartikulāru JIA un jaunākā vecuma bērniem (jaunākiem par 6 gadiem) ar poliartikulāru JIA, kas norāda uz līdzībām šajās JIA apakšklasēs, bet šī alēle bija retāka vecākiem bērniem ar poliartikulāru JIA (Hollenbach et al., 2010). Somu pêtījumā kā iespējamas slimības riska alēles izrādījās DRB1*0801 un DRB1*1101, savukārt DQA1 un citām HLA alēlēm bija krietni mazāka loma (Runstadler et al., 2003).

Ir konstatēts, ka dažas HLA alēles vai to kombinācijas ir saistītas ar augstāku slimības riska sākumu jaunākā vecumā, piemēram, DRB1:08:01 un DRB1:11:03/11:04 (Murrey et al., 1999). Grieḳu pētījumā DRB1*11 ( $p=0,04)$, DQA1*0501 ( $p=0,04)$ un DQB1*0301 $(p=0,01)$ alēles ievērojami biežāk bija sastopamas pacientiem, kam JIA slimības sākumā artrīts tika konstatēts mazāk nekā 5 locītavās. Asociācijas ar HLA alēlēm šajā pētījumā ir meklētas dažādās pacientu grupās, piemēram, pacientiem ar hronisku priekšēju uveītu neatkarīgi no vecuma slimības sākumā un gaitas ievērojami biežāk nekā kontroles grupā tika atrastas alēles DRB1*13, DPB1*0201, DQA1*0501 un DQB1*0301 (Pratsidou-Gertsi et al., 1999).

HLA II klases alēles pacientiem ar juvenilu idiopātisku artrītu ir pētītas arī Latvijā. Rumbas un kolēǵu pētījumā tika konstatēts, ka šiem pacientiem biežāk sastopamā alēle ir DQA1*03, savukārt DRB1*01-DQA1*0101-DQB1*0501 varētu būt ar protektīvu nozīmi. Kaut arī dažādu slimības tipu gadījumā dažas alēles tika konstatētas biežāk, statistiski ticamas atšķirīibas neapstiprinājās (Rumba u. c., 1997). 


\subsection{TML artrīta diagnostika}

\subsubsection{Subjektīvās sūdzības, objektīvā klīniskā atrade, TML artrīta skrīnings}

Asimptomātiska TML artrīta norise, pēc dažādu pētījumu datiem, var būt pat līdz 71\% (Koos et al., 2014; Weiss et al., 2008; Argyropoulou et al., 2009). Millers un kolēgei analizēja 30 JIA slimniekus, kuri tika izmeklēti reimatoloǵiski, ortodontiski, ar USG un MRI. Par zelta standartu izvēloties MRI rezultātu, tika konstatēts, ka reimatoloǵiskā izmeklēšana 15 pacientiem ar TML artrītu sakrita ar MRI rezultātu; 7 pacientiem, kuriem reimatologisiskā izmeklēšanā bija TML artrīta simptomi, tas MRI neapstiprinājās; 4 pacientiem nebija klīnisku artrīta pazīmju, bet TML artrīts tika diagnosticēts ar MRI. Līdzīgi rezultāti tika sasniegti, veicot arī ortodontisko izmeklēšanu. Ar USG metodi rezultāti bija salīdzinoši sliktāki, jo tikai 10 pacientiem tika diagnosticēts TML artrīts un 8 pacientiem bija nepatiesi negatīvi rezultāti (Müller et al., 2009).

Kristensens un kolēgi plašā literatūras pārskatā ir konstatējuši, ka pētījumos biežāk minētās subjektīvās sūdzības ir sāpes, samazinātas TML funkcijas un dažādas skaņas TML kustību laikā (Kristensen et al., 2016).

Visbiežāk JIA slimnieku funkcionālo spēju subjektīvai izvērtēšanai tiek izmantota latviešu valodā validētā bērnu veselības aptaujas lapa CHAQ (Chidlhood Health Assesement Quetionnaire), kas ietver dažādus jautājumus par ikdienā veicamām aktivitātēm un spēju tās izpildīt. Diemžēl šajā aptaujas lapā nav ietverti jautājumi, kas norādītu uz iespējamām TML funkciju problēmām. CHAQ arī šajā pētījumā palīdz izvērtēt vienīgi vispārējo funkcionālo spēju, kas saistāma ar slimības kopēju gaitu. Tas pats attiecas uz vizuālo analogu skalu (VAS) par sāpēm. Standarta reimatoloǵiskā izmeklēšanā pacients ar 10 iedaḷu vizuālo analogu skalu novērtē sāpes kopumā visās locītavās pēdējās nedēḷas laikā (Rumba et al., 2001).

Ierodoties pie reimatologa uz vizīti, pacienti reti iedomājas saistīt sāpes TML rajonā ar artrītu, tādēl ir svarīgi uzdot mērḳtiecīgus jautājumus. Subjektīvās sūdzības var būt ḷoti dažādas - sāpes, košḷājot cietāku barību, žāvājoties, dziedot, runājot, var būt rīta stīvums šajās locītavās, galvassāpes, krakšḳēěana, klikšķēěsana, skaņas ausīs. Parasti JIA slimniekiem nav sūdzību par nepārtrauktām sāpēm TML rajonā, bet vairāk par sāpēm noteiktu kustību, piemēram, košlāăšanas, laikā, kā arī plati atverot muti, kas parādās reizi nedẹḷā vai biežāk sk. 2.2. tabulu (Stoustrup, Koos, 2015).

Sāpes TML rajonā var būt arī citu iemeslu dēḷ. Tās var būt saistītas gan ar TML, gan ar zobu, ausu patolog̣iju, siekalu dziedzeriem, košanas muskulatūras traucējumiem, 
mugurkaula kakla dalı vai galvu. Viens no sāpju iemesliem var būt arī bruksisms jeb zobu griešana, tādēḷ svarīga ir detalizēta anamnēze (Fam et al., 2006).

TML artrīts ir tikai viena no apakšproblēmām patoloğiju grupā, ko sauc par TML traucējumiem, kuru cēlonis var būt dažādas patoloǵijas, piemēram, TML diska dislokācija, arī psihosomatiski traucējumi (Stoustrup \& Koos, 2015).

Viens no TML rajona sāpju iemesliem var būt tā saucamais Kostena sindroms, paz̄īstams arī kā miofasciālas temporomandibulāras sāpes un disfunkcija, kas ir samērā bieži sastopams galvas un mugurkaula kakla daḷas sāpju iemesls. Sāpes ir saistītas ar košanas muskuḷu disfunkciju. Raksturīgi, ka šiem pacientiem atšķirībā no TML artrīta slimniekiem sāpes vairāk ir lokalizētas košanas muskuḷu rajonā un asociējas ar fibromialǵijas sindromam raksturīgām problēmām, tādām kā trauksme, depresija, tensijas tipa galvassāpes, miega traucējumi. Abramovičs un kolēgi pētīja 61 JIA slimnieku un konstatēja, ka 34,4\% no tiem ir aktīvs TML artrīts, 34,4\% - miofasciālais sāpju sindroms, savukārt 18\% slimnieku bija abu iepriekš minēto patoloǵiju kombinācija (Abramowicz et al., 2013; Fam et al., 2006; Ropper et al., 2016).

Subjektīvās sūdzības par TML traucējumiem ne vienmēr korelē ar MRI atradi. Ma un citi konstatēja, ka 32/48 (67\%) pacientu ar aktīvām izmaiņām MRI un arī 5/19 (21\%) pacientiem bez MRI izmaiṇām anamnēzē bija sūdzības par TML traucējumiem - sāpes, samazināts mutes atvērums vai krepitācija pēdējo divu nedēḷ laikā ( $M a$ et al., 2015). Vairākos pētījumos konstatēts, ka sāpes nekorelē vai vāji korelē ar MRI atradi, piemēram, Kellers un citi konstatēja, ka tikai 37\% pacientu bija sāpes TML apvidū, Tvilta un citi konstatēja, ka tikai 11 no 97 bērniem ir sāpes, tomēr pētījumu rezultātus ietekmē tas, cik detalizēti ir ievākta anamnēze un vai aptaujā par sūdzībām ir izmantota speciāla anketa (Keller et al., 2015; Twilt et al., 2004; Müller et al., 2009, Weiss et al., 2008).

2.2. tabula

Ar TML artrītu saistītie simptomi un pazīmes*

\begin{tabular}{|l|l|}
\hline Simptomi & Pazīmes \\
\hline Sāpes vai grūtības košľāšanas laikā & Samazināts mutes atvērums \\
Sāpes, maksimāli atverot muti & Apaǩ̌̌ckḷa deviācija maksimāla mutes atvēruma \\
TML rīta stīvums & gadījumā̄ \\
Noguruma sajūta TML rajonā & Samazināta protrūzija, laterālas kustības \\
Galvassāpes & Asimetriska protrūzija \\
Sāpes kakla rajonā & TML krepitācija \\
Citi, retāki simptomi & Sāpes un/vai jutīgums palpācijas laikā TML un \\
& košanas muskulos \\
& Samazināts sakodiena spēks \\
\hline
\end{tabular}

* Adaptēta no Stoustrup \& Koos, 2015. 
Izmeklējot juvenila idiopātiska artrīta slimniekiem TML, objektīvi:

1) vizuāli tiek vērtētas tādas pazīmes kā pietūkums, apsārtums, simetrija. Pietūkumu TML artrīta gadījumā novēro reti. Arī apsārtums nav raksturīgs hroniska artrīta pacientiem. Ja locītavā jau notikušas strukturālas izmaiņas, vizuāli var novērot mikrognātiju vai retrognātiju;

2) palpācija tiek veikta, novietojot rādītājpirkstus priekšā ārējai auss ejai un palūdzot pacientu atvērt muti. Mutes atvēršanas brīdī eksaminētāja pirksts ieslīd TML bedrītē. Tiek novērtēta lokālā temperatūra, jutīgums, izsvīdums, krepitācija, klikšķěšana;

3) tiek novērtētas kustības - mutes atvēršana, kā arī apakšžokḷa deviācija. Mutes atvērumu mēra ar metāla lineālu starp pacienta centrālajiem priekšzobiem, mutei jābūt maksimāli atvērtai. Normā šis attālums vecumā līdz 10 gadiem ir vismaz 35 mm, savukārt vecākiem bērniem vismaz $40 \mathrm{~mm}$. Tiek vērtēta arī apakšžokḷa deviācija attiecībā pret augšžokli, kas normā ir mazāka par $2 \mathrm{~mm}$ (Fam et al., 2006).

No objektīvās atrades vairākos pētījumos konstatēts, ka samazināts mutes atvērums pat līdz 6,7 reizēm palielina TML artrīta iespēju (Abramowicz et al., 2013; Stoll et al., 2012; Müller et al., 2009). Noskaidrots arī, ka apakšžokḷa deviācija, atverot muti, ir ar augstu specifitāti, bet zemu sensitivitāti (Abramowicz et al., 2013). Kellera pētījumā pacientu mutes atvērums ir salīdzināts ar veselu bērnu ortodontiskās izmeklēšanas rezultātiem atbilstoši vecuma un dzimuma percentilēm (20719 bērnu kohorta) un konstatēts, ka vidējais mutes atvērums pacientiem bija tikai par $0,2 \mathrm{~mm}$ un $0,6 \mathrm{~mm}$ (attiecīgi reimatologa un ortodonta veiktā izmeklēšanā) mazāks nekā kontroles grupā, vidēji 47,4 mm un 49,4 mm. Tomēr, salīdzinot ar MRI atradi, Kellers un citi secināja, ka samazināts mutes atvērums norāda uz TML deformāciju un nevar tikt izmantots agrīnu iekaisuma radītu izmaiṇu diagnosticēšanai (Keller et al., 2015). Savukārt Stenks un citi secina, ka informatīvāki ir regulāri mutes atvēruma mērījumi dinamikā, bet vienreizējam mērījumam ir mazāka nozīme un tā interpretācija reizēm var būt apgrūtināta (Steenks et al., 2015). Jebkurā gadījumā mutes atvērums ir būtisks TML bojājuma rādītājs, kas regulāri jāizvērtē katram JIA slimniekam.

Kellers un citi ir konstatējuši, ka TML klīniskie simptomi korelē tikai ar strukturālām izmaiņām MRI (Keller et al., 2015). Tomēr ir svarīgi, kādi klīniskie simptomi tiek izvērtēti un reǵistrēti. Dažādos pētījumos tie atšķiras. Kellera pētījumā reimatoloǵiskā izmeklēšanā tika izvērtēts pietūkums, sāpīgums, kustību apjoma ierobežojums, tika palpētas TML, mērīts maksimālais mutes atvērums starp incisālajiem zobiem, novērtēta vizuālā asimetrija, retrognātija. Tomēr TML artrīta simptomi var būt arī galvassāpes, skaṇas ausīs, sāpes košanas 
muskulatūras un deniņu muskulatūras apvidū u. c. Izvērtējot TML, jāṇem vērā, ka sāpes var būt ne tikai locītavu rajonā, bet arī sejas, biežāk košanas, muskuḷos.

Praksē locītavu izmeklēšanai tiek izmantoti dažādi skrīningi. Muskuloskeletālās sistēmas izvērtēšanai primārās aprūpes speciālistiem tiek ieteikts pediatriskais gaitas, roku, kāju un muguras skrīnings jeb pGALS (paediatric Gait Arms Legs and Spine) (Foster, Jandial, 2013). Šajā skrīningā ir iekḷauta arī TML izmeklēšana, kas tiek veikta, lūdzot pacientu šķērseniski ievietot mutē trīs rokas pirkstus, tādējādi izvērtējot mutes atvērumu un apakšžokḷa deviāciju. Šajā skrīningā netiek iekḷauti papildu jautājumi par subjektīvām sūdzībām saistībā ar šìm locītavām, kā arī nav paredzēta deniṇu un košanas muskuḷu palpācija.

Bērnu reimatologi praksē izmanto detalizētāku locītavu izmeklēšanu, piemēram, 71 locītavas izmeklēšanu, kas savukārt integrēta slimības aktivitāti raksturojošā skalā jeb JADAS-71 (Juvenile Arthritis Disease Activity Score). JADAS sev̄i ietver aktīvo locītavu skaitu, normalizēto EGĀ vai CRP, pacienta/vecāku VAS vispārējo vērtējumu par slimību (diapazonā no 0 līdz 10), kā arī ārsta VAS vērtējumu par slimības aktivitāti (diapazonā no 0 līdz 10). Šajā gadījumā locītavas tiek izvērtētas, ņemot vērā pietūkumu, kustību ierobežojumu un sāpes kustību vai palpācijas laikā. Locītava tiek uzskatīta par aktīvu, ja tajā novēro pietūkumu vai sāpes un kustību ierobežojumu. Sāpes tikai palpācijas laikā bez kustību ierobežojumiem netiek uzskatītas par aktīvas locītavas pazīmēm (Consolaro et al., 2016). Izvērtējot TML tikai ar š̄i skrīninga palīdzību, tāpat kā pGALS skrīningā netiek paredzēta muskuḷu palpācija un apakšžokḷa deviācijas novērtēšana.

Svarīgi ir izveidot vienkāršu un unificētu skrīningu TML izvērtēšanai praksē. Šādu skrīningu izveidoja un rekomendēja lietot darba grupa TML artrīta problēmām veltītajā konferencē Ķ̄îlē 2011. gadā.

TML artrīta skrīnings (5 soli) (Bernd Koos, the EURO tmJOINT collaborative suggestion, 2011, Kiel):

1) TML palpācija - sāpīga vai nesāpīga (palpācijas laikā mute aizvērta un relaksēta);

2) musculus masseter palpācija - sāpīga vai nesāpīga (palpācijas laikā mute aizvērta un relaksēta);

3) musculus temporalis palpācija (palpācijas laikā mute aizvērta un relaksēta);

4) mutes atvērums (starp priekšzobiem; pacients pats atver muti, cik plati spēj):

a) $\operatorname{li} \mathrm{dz} 10$ gadu vecumam $\leq 35 \mathrm{~mm}$ vai normāls;

b) vecākiem par 10 gadiem $\leq 40 \mathrm{~mm}$ vai normāls

c) atkārtotas vizītes gadījumā - vai mutes atvērums samazinājies par $7 \mathrm{~mm}$ vai vairāk); 
5) maksimāla mutes atvēruma gadījumā - deviācija vairāk par 2 mm vai norma.

Minētais skrīnings tika izmantots, izmeklējot mūsu pētījumā iekḷautos pacientus. Tomēr pēdējos gados publicētas arī citas iespējamā skrīninga versijas, piemēram, Stenks un citi 2015. gadā publicējuši 3 minūšu skrīningu, kas sastāv no:

- pieciem (5) ar anamnēzi saistītiem jautājumiem, uz kuriem jāatbild ar jā vai nē:

1) košļāšanas problēmas;

2) vai ēd lēnāk nekā citi;

3) vai ir grūti ēst cietāku barību;

4) vai ir sāpes ēdot;

5) vai ir samazināts mutes atvērums,

• un sešiem (6) klīniskās izmeklēšanas darbībām:

1) vai ir samazināts mutes atvērums (par normu pieņemtas identiskas vērtības kā Kosa skrīningā);

2) krepitācija;

3) sāpes maksimāla mutes atvēruma gadījumā;

4) deviācija maksimāla mutes atvēruma gadījumā (> $2 \mathrm{~mm})$;

5) vai ir redzama asimetrija;

6) retrognātija (Steenks et al., 2015).

Kopējais skrīninga punktu skaits ir 11. Sākotnēji pētījumā tika pieņemts, ka jau viena pazīme var liecināt par TML artrītu. Izvērtējot skrīninga korelāciju ar JADAS-27, tika noskaidrots, ka vismaz divas pazīmes uzskatāmas par labāku indikatoru iespējamam TML bojājumam. Skrīninga korelācija tika vērtēta tieši ar JADAS-27, jo šajā skalā nav iekḷauta TML izmeklēšana, tādējādi izslēdzot TML izmeklējuma ietekmi uz JADAS vērtību.

Kopumā, izvērtējot TML artrìta subjektīvās sūdzības un simptomus, Stoustrups un Koos rekomendē atcerēties par:

1) pacienta sūdzībām;

2) klīniskajām pazīmēm - TML, musculus masseter un musculus temporalis palpāciju;

3) kraniofaciālās morfoloǵijas un augšanas īpatnībām - mutes atvērumu, kā arī zoda deviāciju uz sāniem maksimāla mutes atvēruma laikā (Stoustrup \& Koos, 2015). 


\subsubsection{Ultrasonogrāfija}

USG ir metode, kas ir viegli pieejama, relatīvi lēta un neinvazīva, bez radioaktīvā starojuma un kopumā bērnu reimatoloǵijā tiek plaši lietota, lai diagnosticētu akūtu iekaisumu un šķidrumu locītavas somiņā, sinoviālā apvalka sabiezējumu, tenosinovītu. Tomēr pētījumi rāda, ka atsevišķu locītavu, tai skaitā sakroileālo locītavu un TML, izmeklēšanā šì metode nav pietiekami sensitīva (Sheybani et al., 2013).

Millera pētījumā secināts, ka USG nevar izmantot par ticamu skrīningu TML artrītam, jo grūti izvērtēt visas locītavas struktūras - īpaši ierobežota ir iespēja izvērtēt mediālo locītavas projekciju. USG metodei tika konstatēta augsta specifitāte, bet zema sensitivitāte. USG izmeklējuma rezultāts ir ḷoti atkarīgs arī no operatora subjektīvās uztveres (Müller et al., 2009). Veisa un kolēǵu pētījumā aktīvas TML artrīta pazīmes ar USG metodi netika diagnosticētas nevienā gadījumā, hroniska artrīta pazīmes 32 pacientu grupā atrada 69\% gadījumu ar MRI un 28\% gadījumu ar USG (Weiss et al., 2008).

Attīstoties USG tehnoloǵijām, kā arī veicinot bērnu reimatologu iesaistīšanos vizuālās diagnostikas aktivitātēs, tai skaitā USG, šī situācija var mainīties. Augstas izsķirtspējas USG var tik izmantota TML artrīta diagnostikā gadījumos, kad MRI nav pieejama, ir kontrindicēta, kā arī lai novērtētu procesu dinamikā. USG ir priekšrocības, novērtējot locītavas diska dislokāciju un intraartikulāro šķidrumu, savukārt mazāk iespēju ar šo metodi ir diagnosticēt osteoartīta pazīmes (Fuente et al., 2016; Assaf et al., 2013; Jank et al., 2007; Melis et al., 2007).

\subsubsection{Konvencionālā rentgenogramma, datortomogrāfija un konusa staru datortomogrāfija}

Vēsturiski visbiežāk lietotā metode artrīta diagnostikā ir bijusi konvencionālā rentgenogramma, tomēr iekaisuma diagnosticēšana preerozīvā fāzē ar šo metodi ir ierobežota. Lielākoties ar to tiek izvērtēti apakšžokḷa kondiḷi, to saplacinājums vai reizēm pat to trūkums. Lai redzētu erozijas, vispirms jānotiek izmaiṇām locītavas skrimslī, respektīvi, tās ir vēlīnas iekaisuma sekas (Sheybani et al., 2013; Larheim et al., 2015). TML vizualizāciju ar Rtg ierobežo uzslāņojumi no apkārtējiem kaulu audiem, kas apgrūtina tādu pazīmju diagnosticēšanu kā mīksto audu tūska, izsvīdums, fokāla periartikulāra osteopēnija (Sheybani et al., 2013).

Panorāmiskā tomogrāfija sniedz 2-dimensionālu žokḷu attēlu, kas tiek izmantots, lai izvērtētu kondiḷu patologiiju un novērtētu apakšžokḷa asimetriju, tomēr ar tās palīdzību nav iespējams identificēt neliela izmēra kaulu bojājumus (Al-Shwaikh et al., 2016). 
Ar datortomogrāfijas palīdzību iespējams vizualizēt kaulu strukturālās izmaiṇas, ko nevar diagnosticēt ar konvencionālo Rtg, kā arī locītavu iespējams izvērtēt trijās dimensijās. Lai precīzāk izvērtētu patolog̣iskās izmaiņas, ir izveidotas no dzimuma un vecuma atkarīgas normas kondiḷu un fossa glenoidalis formai un izmēriem (Karlo et al., 2010). Tomēr datortomogrāfijai ir zema sensitivitāte agrīnu iekaisuma izmaiṇu diagnostikāa kā arī jārēḳinās ar lielu starojuma devu (Fuente et al., 2016).

Konusa staru datortomogrāfija Eiropā tiek lietota kopš 1996. gada. Tās gadījumā tiek lietots konusu veidojošs rentgena starojums. Ar ātru rentgena staru un digitālā detektora $180^{\circ}$ vai biežāk $360^{\circ}$ rotāciju tiek iegūts 2 -dimensionāls vai 3-dimensionāls attēls. Salīdzinot ar panorāmiskajiem rentgena uzṇēmumiem, īsākā laikā un ar zemu radiācijas devu iespējams iegūt daudz attēlu (Farman, Scarfe, 2009).

Konusa staru datortomogrāfijas rezultāti liecina, ka JIA slimniekiem novēro nozīmīgu apakšžokḷa kondiḷu asimetriju, kā arī dažādas pakāpes destrukciju, sākot ar erozijām un beidzot ar gandrīz pilnīgu galviṇu deformāciju (Huntjens et al., 2008). Rīgas Stradiņa universitātes Stomatologiijas institūta ortodonti, izmeklējot JIA slimniekus ar konusa staru datortomogrāfiju, kā biežāko patologiiju atrada apakšžokḷa kondiḷu galviṇu saplacinājumu, nedaudz retāk - erozijas un osteofìtus. Savukārt kontroles grupā reizēm tika atrasts viegls kondiḷu saplacinājums, kas var būt arī normāls attīstības variants (Al-Shwaikh et al, 2016).

\subsubsection{Magnētiskās rezonanses izmeklējums}

Ar MRI metodi iespējams izvērtēt visas TML struktūras (Larheim et al., 2015). Pateicoties MRI ar kontrastvielu, TML artrīta agrīna diagnostika ir ievērojami uzlabojusies (Müller et al., 2009; Ringold, Cron, 2009). Pašlaik MRI tiek uzskatīta par TML artrīta skrīninga metodi pat bez klīniskajiem simptomiem un īpaši - pacientiem ar augstāku risku (Argyropulou et al., 2009; Pedersen et al., 2008; Weiss et al., 2008). Hausers un kolēǵi retrospektīvi izvērtēja no jauna diagnosticētu 111 JIA slimnieku MRI, kas veikti 5 mēnešu laikā no diagnozes noteikšanas brīža. TML artrīts tika konstatēts $82 \%$ pacientu. Šis pêtījums pierādīja MRI nozīmi ārstēšanas taktikas izvēlē, jo tieši MRI izmeklējuma rezultāti noteica ārstēšanas taktiku - 60 pacienti saṇēma intraartikulāru glikokortikoīdu injekciju, savukārt 9 pacientiem tika uzsākta sistēmiska terapija (Hauser et al., 2014).

Pētījumos apstiprināts, ka, salīdzinot ar klīnisko un USG izmeklēšanu, ar MRI tiek atklāti vairāk TML artrīta gadījumu (Weiss et al., 2008). 
Lielākoties TML artrīts, izmeklējot ar MRI, tiek konstatēts bilaterāli, bet ar konvencionālo rentgenogrammu - biežāk unilaterāli, kas liecina par augstāku MRI metodes sensitivitāti (Müller et al., 2009; Larheim et al., 2015).

Par akūtām TML artrīta pazīmēm MRI tiek uzskatītas: pastiprināta sinoviālā apvalka kontrastēšanās (tiek vērtēta pretrunīgi), izsvīdums, sinoviālā apvalka sabiezējums, kaula smadzeņu tūska. MRI reizēm grūti atšķirt sinoviālo apvalku no locītavas izsvīduma un locìtavas kapsulas, tādēl daži autori ieviesuši terminu "locītavas mīkstie audi" (Kalle et al., 2013; Kellenberger et al., 2015; Meyers, Laor, 2013; Müller et al., 2009; Vaid et al., 2014). Agrīnākā TML artrīta pazīme ir sinoviālā apvalka kontrastēšanās, kas var būt viegla, vidēja vai smaga. Otrā biežākā pazīme ir izsvīdums locītavas somiṇā. Sākotnēji TML artrīta gadījumā izsvīdums locītavā var būt pavisam neliels, savukārt vēlīnās artrīta fāzēs tā vairs nav. Savukārt kaula smadzeņu tūsku var novērot gan agrīnās, gan vēlīnās artrīta fāzēs (Vaid et al., 2014).

Ilglaicīga slimība var radīt pannus veidošanos, skrimšla bojājumu (tas kḷūst plānāks un var pat izzust), subhondrālā kaula bojājumu ar erozijām, diska deformācijas un nepareizu novietojumu, kondiḷu un locītavas bedrīšu saplacinājumu, kaulu destrukciju, hipertrofisku kaula veidošanos - osteofìtus, mikrognātiju (Kellenberger et al., 2015; Meyers, Laor, 2013; Müller et al., 2009; Vaid et al., 2014).

Līdz šim TML MRI atrade daḷēji ir balstījusies uz pieredzējuša radiologa subjektīvo vērtējumu. Piemēram, sinoviālā apvalka kontrastēšanās parasti tiek vērtēta kā viegla, vidēja vai izteikta. Kellera pētījumā sinoviālā apvalka kontrastēšanās ir vērtēta kā viegla, kad signāla intensitāte līdzvērtīga muskuliem, bet kā smaga, ja signāla intensitāte līdzvērtīga asinsvadiem (Keller et al., 2015). 2015. gadā publicētā pētījumā par TML MRI ir meklēta iespēja objektivizēt atradi, izmantojot kvantitatīvas metodes, lai izvērtētu sinoviālā apvalka un apakšžokḷa kondiḷu kontrastēšanās intensitāti, kas nākotnē, iespējams, dos iespēju precīzāk noteikt procesa aktivitāti (Ma et al., 2015). Tomēr sinoviālā apvalka kontrastēšanās kā akūta artrīta pazīme ir vērtēta arī pretrunīgi; piemēram, Veiss un kolēgi savā pētîjumā, ņemot vērā radiologu praktisko pieredzi, sinoviālo kontrastēšanos izvēelējušies nevērtēt kā artrīta pazīmi, jo novērojuši to dažādās pakāpēs arī bērniem bez JIA un TML iesaistes (Weiss et al., 2008). Savukārt citos pētījumos viegla sinoviālā kontrastēšanās novērota kā normas variants bērniem, kam MRI galvai veikts citu iemeslu dẹl, un varētu būt vien intensīvākas apasiņošanas pazīme (Kalle et al., 2013; Moe et al., 2016). Tāpat arī T2 attēlos arī veseliem bērniem novēro locītavas šḳidruma slānīti (Müller et al., 2009). 
Novērtējot kondiḷus, jāṇem vērā, ka viegli saplacinātas kondiḷu galvas dažkārt sastop arī veseliem bērniem un izolēti nav uzskatāmas par artrīta pazīmi, ja vien dinamikā neparādās citas morfoloğiskas izmaiņas (Arvidsson et al., 2009).

Jārēḳinās, ka arī MRI ir subjektīvs izmeklējums. Veisa (Weiss et al., 2008) pētījumā, salīdzinot divu radiologu atradi, konstatēts, ka kopumā attiecībā uz jebkurām aktīva vai hroniska iekaisuma pazīmēm radiologiem bija 100\% vienprātība ar kappa koeficientu 1,0, bet, vērtējot specifiskas pazīmes, piemēram, izsvīduma gadījumā, vienots viedoklis bija tikai 75\% $(\kappa=0,38)$ apjomā, bet sinoviālā apvalka sabiezējuma gadījumā $-62,5 \%$ apjomā $(\kappa=0,33)$.

Lai sistematizētu MRI atradi, Vaids un kolēgi izveidojuši skalu, pēc kuras iesaka vērtēt MRI atradi juvenila idiopātiska artrīta slimniekiem ar aktīvu un/vai hronisku TML bojājumu. Katra puse tiek vērtēta atsevišḳi, savukārt rezultāts tiek saskaitīts atsevišḳi aktīiā iekaisuma un hroniskā iekaisuma pazīmēm. Augstāks vērtējums liecina par smagāku bojājumu (2.3 tabula).

Kopumā MRI metode izmantojama gan agrīnā TML artrīta diagnostikā, gan procesa izvērtēšanai dinamikā, kā arī ārstēšanas efektivitātes novērtēšanai (Vaid et al., 2014).

TML MRI atrades sistematizēts novērtējums (Vaid et al., 2014)

\begin{tabular}{|c|c|c|}
\hline MRI atrade & Kreisā puse & Labā puse \\
\hline $\begin{array}{l}\text { I. Kaula smadzeņu tūska } \\
\text { Nav tūskas }=0 \text { punkti } \\
\text { Ir tūska }=1 \text { punkts }\end{array}$ & & \\
\hline $\begin{array}{l}\text { II. Izsvīdums } \\
\text { Nav }=0 \text { punkti } \\
\text { Viegls difūzs }=1 \text { punkts } \\
\text { Priekšějs vai mugurējs fokāls }=2 \text { punkti } \\
\text { Priekšējs un mugurējs }=3 \text { punkti } \\
\text { Izsvīdums visā locītavas spraugā }=4 \text { punkti }\end{array}$ & & \\
\hline $\begin{array}{l}\text { III. Sinoviālā kontrastēšanās } \\
\text { Nav }=0 \text { punkti } \\
1 \mathrm{~mm} \text { (viegla) }=1 \text { punkts } \\
2 \mathrm{~mm}(\text { vidēja })=2 \text { punkti } \\
\geq 3 \mathrm{~mm}(\text { smaga })=3 \text { punkti }\end{array}$ & & \\
\hline $\begin{array}{l}\text { IV. Kondili } \\
\text { Normāli }=0 \text { punkti } \\
1 / 3 \text { saplacinājums }=1 \text { punkts } \\
2 / 3 \text { saplacinājums }=2 \text { punkti } \\
\text { Pilnīgs saplacinājums }=3 \text { punkti } \\
\text { Kondilu palielinājums }=4 \text { punkti }\end{array}$ & & \\
\hline $\begin{array}{l}\text { V. Disks } \\
\text { Normālā pozīcijā }=0 \text { punkti } \\
1 / 3 \text { destrukcija }=1 \text { punkts } \\
2 / 3 \text { destrukcija }=2 \text { punkti } \\
\text { Pilnīga destrukcija }=3 \text { punkti }\end{array}$ & & \\
\hline
\end{tabular}




\begin{tabular}{|l|l|l|}
\hline \multicolumn{1}{|c|}{ MRI atrade } & Kreisā puse & Labā puse \\
\hline VI. Erozijas & & \\
Nav $=0$ punkti & & \\
$1 / 3$ virsmas $=1$ punkts & & \\
$2 / 3$ virsmas $=2$ punkti & & \\
$3 / 3$ virmsas $=3$ punkti & & \\
\hline VII. Pannus & & \\
Nav $=0$ punkti & & \\
$\leq 1 \mathrm{~mm}=1$ punkts & & \\
$1-2 \mathrm{~mm}=2$ punkti & & \\
$\geq 3 \mathrm{~mm}=3$ punkti & & \\
\hline VIII. Osteofìti & & \\
Nav $=0$ punkti & & \\
1 vai vairāk $=1$ punkts & & \\
\hline
\end{tabular}

Kopējā aktīvā iekaisuma skala (0-8) Kreisā puse

Labā puse (I, II, III sadaḷa)

Kopējā hroniskā iekaisuma skala (0-14) Kreisā puse Labā puse (IV, V, VI, VII, VIII sadaḷa)

\subsubsection{Agrīnas un kombinētas diagnostikas nozīme}

Vairākos līdz šim veiktajos pētījumos par TML artrītu piedalījušies gan reimatologi, gan ortodonti un stomatologi, gan arī radiologi, kas liecina par šo jomu speciālistu sadarbības nepieciešamību JIA un TML artrīta slimnieku aprūpē (Ferraz Junior et al., 2012; Carvalho et al., 2012).

Bernds Koos un kolēgi ir mēginājuši klasificēt MRI un konusa staru datortomogrāfijas atradi, lai atvieglotu ārstēšanas taktikas izvēli. Klasifikācijā ir ietverta konusa staru datortomogrāfijas atrade, kas raksturo locītavas deformāciju un/vai destrukciju, savukārt MRI rezultāts atspoguḷo iekaisuma procesu dažādās pakāpēs atbilstoši tam, vai ir sinoviālā apvalka kontrastēšanās un cik tā izteikta, vai ir kaulu tūska un sinoviālā apvalka hipertrofija. Minētie dati tika salīdzināti ar kontroles grupu, kurā konstatēja vieglu sinoviālu kontrastēšanos, kas, kā iepriekš minēts, var būt uzskatāma par normas variantu, kāa arī vieglas strukturālas izmaiņas, tomēr artrīta grupā 83\% gadījumu bija smagas strukturālas izmaiņas. Tomēr tiek diskutēts, vai vienmēr konusa staru datortomogrāfijas radītais starojums atsver izmeklējumā iegūto informāciju, tādēl jāṇem vērā, ka šie dati vairāk indicēti gadījumos, kad nepieciešama ortodontiska terapija (Koos et al., 2013).

Agrīna diagnostika ir būtiska, jo ir noskaidrots, ka apakšžokḷa kondiḷi spēj reǵenerēties. Tvilta un kolēgi pētīja pacientu grupu ar 5 gadu intervālu un konstatēja, ka 69\% 
pacientu tika novērota uzlabošanās, kas tika saistīta arī ar zemu slimības aktivitāti, kas savukārt, iespējams, ir saistīta ar agrīnu un agresīvu terapiju (Twilt et al., 2008).

Multinacionālā 2014. gada pētījumā tika konstatēts, ka uz to brīdi TML artrīta skrīningam nav vienotas pieejas, tomēr ir skaidrs, ka diagnostikā ir būtiski kombinēt dažādas metodes (Foeldvari, Tzaribachev \& Cron, 2014).

2017. gadā ir publicētas starptautiskas rekomendācijas JIA slimnieku monitorēšanai attiecībā uz TML artrītu gan klīniskajā praksē, gan arī pētījumos, 40 ekspertu darba grupa vienojās par 5 rekomendācijām orofaciālai izmeklēšanai pacientiem ar JIA (Stoustrup et al., 2017):

1) slimības anamnēzes dati: dzimums, vecums izmeklēšanas brīdī, JIA tips, slimības ilgums, agrāk un izmeklēšanas laikā lietotie medikamenti, agrākā un izmeklēšanas laikā lietotā ortodontiskā terapija, slimības aktivitāte;

2) pacientam ir jājautā par orofaciāliem simptomiem, precizējot lokalizāciju, intensitāti, biežumu, raksturu un apstākḷus, kuros simptomi parādās. Šajā sakarā darba grupa plāno izveidot speciālu aptaujas lapu;

3) klīniskā orofaciālo simptomu izvērtēšana ietver TML palpāciju, košanas un deniņu muskuḷa palpāciju, sāpju izvērtēšanu palpācijas laikā un pie apakšžokḷa kustībām, locītavas skaņu novērtēšana (krakšķēěsana, klikšķēěsana u. tml.);

4) klīniskā orofaciālo funkciju izvērtēšana - maksimālais mutes atvērums, deviācija, atverot muti, protrūzija, laterotrūzija, kondiḷu translācija (slīdēšana uz priekšu un atpakaḷ), atverot muti;

5) klīniskā sejas morfolog̣ijas un simetrijas novērtēšana, apakšžokḷa sagitālās pozīcijas izvērtēšana, sejas apakšèjās daḷas asimetrijas novērtēšana frontālā plaknē.

Lai realizētu šādu izmeklēšanu katram JIA slimniekam, nepieciešama reimatologu un ortodontu cieša sadarbība (Stoustrup et al., 2017).

\subsection{TML artrīta vispārējās un lokālās terapijas iespējas}

JIA ārstēšana ir medikamentoza un nemedikamentoza. Mūsdienu JIA vadlīnijas attiecībā uz medikamentozo terapiju nosaka, ka poliartikulāra JIA ārstēšana tiek uzsākta ar sintētiskiem slimību modificējošiem medikamentiem - visbiežāk metotreksātu (MTX), bet, ja š̀i terapija nav pietiekami efektīva, tiek pievienoti bioloǵiskie slimību modificējošie medikamenti, no kuriem Latvijā tiek lietoti etanercepts, adalimumabs, abatacepts vai tocilizumabs, atsevišķos gadījumos anakinra (Latvijas Pediatru reimatologu asociācija. Juvenila idiopātiska artrīta klīniskās vadlīnijas. Nacionālais veselības dienests, rīkojums 
21.06.2016. Nr. KV 03-2016). Uzsākot terapiju, kā arī paasinājumu gadījumā pārsvarā visi pacienti saṇem arī nesterō̄do pretiekaisuma līdzekḷu (NSPL) kursus, reizēm glikokortikoīdus sistēmiski.

Sistēmiskā artrīta terapija ar MTX un biolog̣iskiem slimību modificējošiem medikamentiem, NSPL un glikokortikoīdiem var mazināt iekaisuma aktivitāti TML, tomēr bieži vien ar šo terapiju nepietiek un TML artrīta simptomi turpinās (Ringold \& Cron, 2009; Stoll et al., 2012.). Šādos gadījumos nepieciešams lemt par intraartikulāras glikokortikoīdu injekcijas veikšanu. Veisa pētījumā pacientiem, kuriem tika veikta intraartikulāra injekcija, MRI tika atkārtots pēc 6 mēnešiem, un 5 no 6 pacientiem izsvīdums locītavās un/vai sinoviālā apvalka sabiezējums bija mazinājies (Weiss et al., 2008). Intraartikulāro injekciju pozitīvā ietekme, piemēram, simptomu atvieglošana, iekaisuma pazīmju mazināšanās MRI, minēta daudzos pētījumos (Ravelli \& Martini, 2007; Weiss et al., 2008; Arabshahi et al., 2005; Stoll et al., 2012).

Vairākos pētījumos konstatēts, ka intraartikulāras glikokortikoīdu injekcijas palīdz palielināt mutes atvērumu (Weiss et al., 2008; Arabshahi et al., 2005; Ringold, Cron, 2009). Tomēr Stoustrups un kolēgi sistemātiskā literatūras pārskatā konstatē, ka līdzšinējie pētījumi nav pietiekami, lai spriestu par intraartikulāro injekciju efektu un iespējamo ietekmi uz apakšžokḷa augšanu (Stoustrup et al., 2013). Dati no pētījumiem ar dzīvniekiem liecina par iespējamu intraartikulāro sterō̄du negatīvu ietekmi uz apakšžokḷa augšanu (Stoustrup et al., 2008). Ne visos gadījumos intraartikulāro sterō̄du injekcija dod vēlamo rezultātu, piemēram, Stolla un kolēǵu pētījumā 32\% pacientu pēc intraartikulāras steroīdu injekcijas dinamikā konstatēja pasliktināšanos ar jaunu eroziju veidošanos, 16\% pacientu stāvoklis saglabājās nemainīgs, 51\% pacientu artrīta pazīmes mazinājās. Savukārt no blaknēm biežākās ir lokālas audu atrofijas injekcijas vietā. Lai novērstu daḷu no blaknēm, tiek rekomendēts intraartikulārās ievades veikt USG, CT vai MRI kontrolē (Arabshahi et al, 2005; Parra et al., 2010).

Attiecībā uz ārstēšanas metodes izvēli - indikācija intraartikulāro glikokortikō̄du (triamcinolona heksacetonīda vai triamcinolona acetonīda) ievadīšanai TML līdzšinējos pētījumos ir iekaisumam raksturīga atrade MRI (Weiss et al., 2008; Arabshahi et al., 2005; Stoll et al., 2012). Trūkst pētījumu par sistēmiskās terapijas ietekmi uz TML artrītu, kas, iespējams, daḷā gadījumu ir pietiekama, lai mazinātu iekaisumu TML un novērstu locītavas destrukciju. Līdz šim ir tikai viens pētījums par MTX ietekmi uz TML artrītu, kur konstatēts, ka TML bojājums pacientiem, kuri saṇem MTX, ir mazāk izteikts (Ince at al., 1999). Klīnicisti atzīmē, ka agrīna JIA slimnieku ārstēšana ar bioloǵiskajiem medikamentiem mazina 
dažādu locītavu, t. sk. arī TML, deformāciju attīstību, tomēr pētījumu par šo jautājumu līdz šim nav.

Atsevišķos pētījumos ir aprakstītas arī citas TML artrīta terapijas iespējas, piemēram, deksametazona jonoforēze, ko veic caur ādu. Sāpes mazinājās 11 no 15 pacientiem, mutes atvērums uzlabojās 19 no 28 pacientiem (Mina et al., 2011). Ir pētīta arī iespēja intraartikulāri ievadīt biologiskos medikamentus, piemēram, infiksimabu (Stoll et al., 2013), tomēr vēl trūkst pārliecinošu pierādījumu, lai šīs metodes ieviestu plašāk. Eksperimentālā pētījumā ar mākslīgi inducētu artrītu trušiem tika konstatēts, ka sistēmiskai ārstēšanai ar etanerceptu ir priekšrocības salīdzinājumā ar intraartikulāru tā ievadi, tomēr secināts, ka, iespējams, etanercepts locītavās bijis ievadīts nepietiekamā daudzumā (Stoustrup et al., 2009).

Terapijas iespējas un veidus TML artrīta gadījumā var iedalīt arī artrīta un dentofaciālo deformāciju grupās. Otrās grupas pacientu terapijas iespējas ir speciāli veidotas kapes, fizioterapija, ortodontiskā terapija un arī ķirurǵiska ārstēšana (Veldhuis E. C., Veldhuis A. H., Koudstaal, 2014; Farronato et al., 2009).

Nemedikamentozā terapija JIA gadījumā ir lokālas aukstuma aplikācijas sāpošajām locītavām un ārstnieciskā vingrošana. Blakus esošo struktūru dēḷ aukstuma aplikācijas nevar lietot TML artrīta gadījumā, savukārt ārstnieciskās vingrošanas iespējas ir, tomēr Latvijā nav plaši pieejamas, turklāt par šo jautājumu vēl trūkst pētījumu. 


\section{MATERIĀLS UN METODES}

\subsection{Pētîjuma uzbūve}

Prospektīvs škērsgriezuma pētijums, veidots no 4 daḷām:

1) JIA pacientu grupas demogrāfisko un slimību raksturojošo rādītāju analīze;

2) TML artrīta attīstību ietekmējošo faktoru noteikšana pacientu grupā ar TML artrīta pazīmēm MRI - MRI pozitīiajā $(\mathrm{MRI}(+))$ grupā - un bez artrīta pazīmēm MRI - MRI negatīvajā (MRI(-)) grupāa, salīdzinot demogrāfiskos, slimību raksturojošos klīniskos, laboratoriskos un HLA II klases alẹ̄u genotipēšanas datus;

3) subjektīvo un objektīvo klīnisko simptomu izpēte un to saistības ar MRI pazīmēm noskaidrošana, salīdzinot simptomus MRI pozitīvajā un negatīvajā grupā, kā arī atkarībā no aktīva un/vai hroniska iekaisuma pazīmēm;

4) MRI radiolog̣iskās atrades analīze JIA slimniekiem ar TML artrīta simptomiem (simptomātiskiem pacientiem) un pacientiem, kuriem nav TML traucējumu simptomu (asimptomātiskiem pacientiem).

Promocijas darbs veikts valsts terciārās aprūpes iestādē, BKUS Bērnu slimību klīnikā, Radiolog̣ijas nodạ̣ā, un Rīgas Stradiņa universitātes Klīniskās imunolog̣ijas un imunoǵenētikas starpkatedru laboratorijā (KIIS laboratorija) no 2010. līdz 2015. gadam.

Pētîjums apstiprināts ar 2013. gada 6. februāra Centrālās medicīnas ētikas komisijas (CMĒK) sēdē izsniegto atzinumu par atbilstību bioētikas normām: 01-29.1/1 - "Deninuuapakšžokḷa locìtavas saistības ar juvenilo idiopātisko artrītu ǵenētiskās ietekmes izpēte" (sk. 1. pielikumā). Visu pêtījumā iekḷauto bērnu vecāki parakstīja rakstisku informētās piekrišanas formu bērna dalībai pētījumā.

\subsection{Pētījuma subjektu datu atlase un pētījuma populācijas raksturojums}

Pētījumā tika iesaistīts 91 pacients, visi pacienti ārstēti un novēroti BKUS Bērnu slimību klīnikā gan stacionārā, gan ambulatori, visiem diagnosticêts juvenils idiopātisks artrîts atbilstoši ILAR kritēijiem, kā arī laikā no 2010. līdz 2015. gadam veikts MRI ar kontrastvielu TML locītavām.

No pētījumā iekḷautajiem pacientiem 80 pacientiem bija subjektīvas sūdzības un/vai objektīva atrade, kas var liecināt par TML artrītu, bet 11 pacienti bija asimptomātiski, kuriem nebija subjektīvu un/vai objektīvu TML problēmu (bojājumu) simptomu. Šiem pacientiem bija sūdzības par citām locītavām, un, ṇemot vērā literatūrā aprakstîtos riska faktorus, bija augsts TML artrīta risks. 
N̦emot vērā, ka TML artrīta diagnostikas zelta standarts ir MRI ar kontrastvielu, pêtījuma pacientu divas galvenās grupas tika veidotas atkarībā no MRI rezultāta:

1) MRI pozitīvā grupa (MRI(+)): pacienti ar aktīvām sinovīta pazīmēm (kaulu tūska, pastiprināta kontrastvielas uzkrāšanās sinoviālajā apvalkā, izsvīdums, pannus) un/vai locītavā ieejošo struktūru bojājumu (apakšžokḷa kaula galviṇu saplacinājums, deniṇu kaula bedrītes saplacinājums, osteofīti, erozijas). Viegla un simetriska kontrastvielas uzkrāšanās netika uzskatīta par artrīta pazìmi (von Kalle et al., 2013) $(\mathrm{n}=72)$;

2) MRI negatīvā grupa (MRI(-)) - pacienti bez patologiskām MRI izmaiṇām $(\mathrm{n}=19)$.

Pacienti ar izmaiņām MRI (MRI pozitīvā grupa) sīkāk tika iedalīi atkarībā no strukturālā bojājuma:

1) pacienti, kuriem tika konstatēts strukturāls TML bojājums ar vai bez aktīva iekaisuma pazīmēm $(\mathrm{n}=50)$;

2) pacienti, kuriem tika konstatētas tikai aktīvas TML iekaisuma pazīmes $(n=22)$.

Skat. 3.1. attēlu.

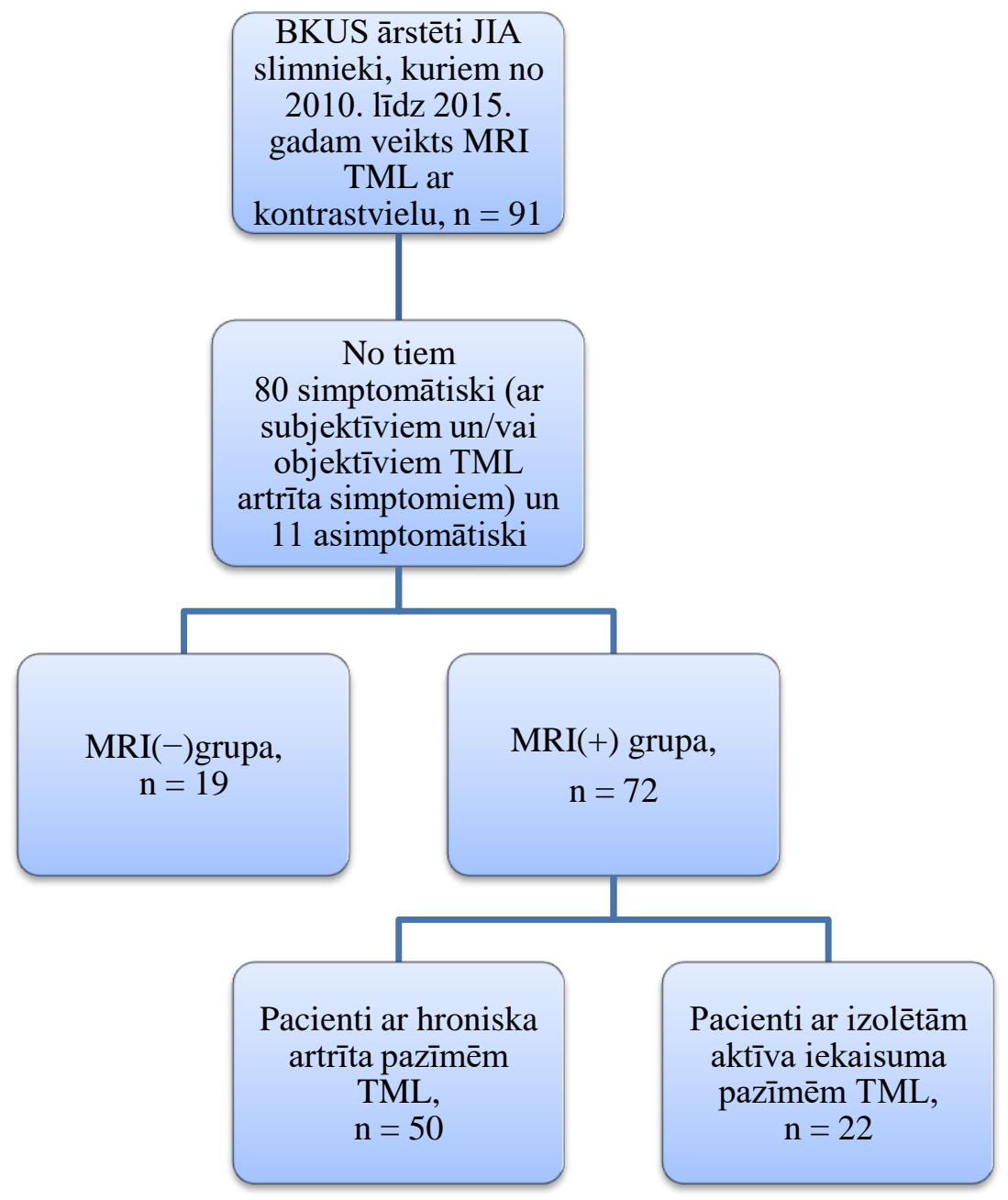

3.1. attēls. Pētījuma grupas 


\subsection{Kontroles grupa}

Veicot imūnǵenētiskos izmeklējumus, kontroles grupā tika iekḷauti 100 nejauši izvēlēti veseli asins donori, kuriem anamnēzē nav datu par autoimūnām slimībām - 47 (jeb 47\%) vīrieši un 53 (jeb 53\%) sievietes, vidējais pacientu vecums ir 18,6 ( $\mathrm{SN}=3)$ gadi, un visi ir Latvijas iedzīvotāji. Pētījumā izmantotais materiāls ņemts no Rīgas Stradiṇa universitātes Imunolog̣ijas un imunoǵenētikas starpkatedru laboratorijas asins bankas.

\subsection{Slimību raksturojošo rādītāju noteikšana}

Aktīvo locītavu skaits - tās ir locītavas ar pietūkumu, kas nav saistīts ar kaulu hipertrofiju, vai locītavas, kurās ir kustību ierobežojums un sāpes kustību vai palpācijas laikā. Šajā pētîjumā par aktīvām tika uzskatītas arī locītavas, kurās konstatēts sinovīts ar USG vai MRI metodi, - arī tajos gadījumos, kad locītava nav aktīva pēc iepriekš minētās definīcijas (Consolaro et al., 2016).

CHAQ (Childhood Health Assessment Quietionnaire) - bērnu veselības novērtējuma aptauja (ir validēta latviešu valodā) tiek izmantota slimības aktivitātes un funkcionālo spēju izvērtēšanai pēdējās nedēḷas laikā pirms vizītes pie ārsta, veicot ikdienas aktivitātes. Pacienti un/vai viņu vecāki tika aptaujāti laikā, kad veikts MRI ( \pm 1 nedēḷa). CHAQ vērtējums ir skalā no 0 līdz 3; augstāks vērtējums nozīmē sliktākas funkcionālās spējas.

VAS (vizuālo analogu skala):

1) ārsta vispārējais bērna slimības vērtējums skalā no 0 līdz $10 \mathrm{~cm}$, kur 0 nozīmē, ka slimības aktivitātes nav, bet 10 ir maksimāla slimības aktivitāte;

2) vecāku un/vai pacienta vērtējums par sāpēm skalā no 0 līdz 10, kur zemāks vērtējums nozīmē mazāk izteiktas sāpes;

3) vecāku un/vai pacientu vērtējums par vispārējo labklājību saistībā ar slimību skalā no 0 līdz 10; augstāks vērtējums nozīmē sliktāku vispārējās labklājības vērtējumu, kas var būt saistīts gan ar slimības izraisītiem traucējumiem, gan arī ar medikamentu lietošanu, atrašanos stacionārā u. tml. (Latvijas Pediatru reimatologu asociācija. Juvenila idiopātiska artrīta klīniskās vadlīnijas. Nacionālais veselības dienests, rīkojums Nr. KV 03-2016 21.06.2016.).

Rīta stīvums locītavās, kas neilgst vairāk par 15 minūtēm, ir viens no kritērijiem neaktīvai slimībai (Wallace et al., 2011) (sk. 6. pielikumu). 


\subsection{Radioloğisko datu analīze}

Tika veikta TML standarta MRI ar kontrastvielu: T1 un T2 FS koronārā plaknē, T1 un T2 slīpi sagitālā plaknē; pēc intravenozas kontrastvielas ievades T1 slīpi sagitāli un T1 FS aksiāli (8-10 minūtes pēc injekcijas). Standarta deva gadolīnu saturošai kontrastvielai ir 0,2 $\mathrm{mL} / \mathrm{kg}$ ķermeņa svara. T1 attēli sniedz informāciju par intraartikulārā diska struktūru un novietojumu. T2 attēli ar tauku supresiju ir sensitīvi attiecībā uz kaula smadzeņu tūsku, izsvīdumu un sinovija proliferāciju.

MRI izmeklējumus aprakstīja divi radiologi. Viedokḷu sakritība tika noteikta ar kappa koeficientu. Rezultātu interpretācijai tika izmantotas Altmana (1999) vadlīnijas (adaptētas no Landis \& Koch, 1977); ja kappa koeficients ir mazāks par 0,20, tas nozīmē vāju viedokḷu sakritību, 0,20-0,40 - apmierinošu, 0,40-0,60 - vidēju, 0,60-0,80 - labu, 0,80-1,00 - l,oti labu sakritību. MRI rezultāti tika dalīti atkarībā no aktīva un/vai hroniska iekaisuma izmaiṇām, tika izvērtēts arī kopējais paz̄imju skaits (sk. 6. pielikumu).

\subsection{Laboratorisko rādītāju analīze}

\subsubsection{Laboratoriskie izmeklējumi slimības diagnostikai un aktivitātes izvērtēšanai}

Laboratoriskie izmeklējumi - CRP, EGĀ, RF, HLA B27 antigēna noteikšana - JIA slimniekiem slimības diagnostikas un aktivitātes izvērtēšanai tika noteikti BKUS Bioḳīmisko izmeklējumu laboratorijā pēc vienas standartizētas metodes. Referentās vērtības minētajā laboratorijā bija šādas: EGĀ visās vecuma grupās zēniem - 0,0-15,0 mm/h, meitenēm - 0,0 20,0 mm/h, savukārt CRP visās vecuma grupās un abiem dzimumiem - 0,0-5,0 mg/L.

RF tika vērtēts kā pozitīvs vai negatīvs, neuzrādot skaitlisko vērtību.

ANA tika noteiktas Paula Stradiṇa Klīniskās universitātes slimnīcas laboratorijā ar imūnfluorescences metodi: par pozitīvu tika uzskatīts titrs $1: 80$; titra lielums netika ņemts vērā, bet vērtējums norādīts tikai kā pozitīvs vai negatīvs.

\subsubsection{HLA II klases alēḷ genotipēěana}

Imūnǵenētiskā pētījuma daḷa tika veikta RSU KIIS laboratorijā. Kā kontroles grupa tika izmantoti 100 KIIS laboratorijas ǵenētiskās bankas veselo indivīdu paraugi. DNS tika ekstrahēts no perifērajām asin̄̄m, izmantojot QiagenQIAamp DNS kitu reaǵentus, kā tas paredzēts ražotāja protokolā (QIAamp DNA Mini and Blood Mini Handbook). DNS kvalitāte un kvantitāte tika pārbaudīta, izmantojot Qubit ${ }^{\circledR}$ fluorometer (Invitrogen, USA). 
HLA genotipēšana pacientu un veselo donoru grupā tika veikta, izmantojot multipraimeru reālā laika polimerāžu ķēžu reakcijas metodi (RT-PCR).

Pacientiem un kontroles grupai tika genotipētas šādas alēles: HLA-DRB1*01:01 līdz 18:01, DQA1*01:01, 01:02, 01:03, 04:01, 06:01 un DQB1*02:01-02:02,*03:01-03:05, *04:01-04:02, *05:01-05:04 un *06:01-06:08. Gēnu tipēšana tika veikta ar zemas izšķiršanas polimerāzes k̦ēdes reakciju (angḷu val. low resolution Real-time PCR, qualitative analysis, melting curve analysis), lietojot sekvences specifiskos praimerus atbilstoši ražotāja noteiktajai metodikai, kas ḷauj identificēt galvenos HLA-DR un HLA-DQ lokusu alēlu tipus (HLA II klases alēḷu genotipēšanas rezultātus sk. 2.-5. pielikumā).

HLA-DRB1*, HLA-DQA1* un HLA-DQB1* gēnu amplifikācija tiek veikta 103 ciklos ar DTLite - termocikleros (DNA-Technology), kas l̦auj uzturēt noteiktu temperatūras režīmu. Sākumā temperatūras ietekmē (aptuveni $94{ }^{\circ} \mathrm{C}$ ) notiek dubultḳēžu DNS denaturācija un vienķēěu DNS veidošanās. Tad temperatūra tiek samazināta vidēji līdz $64{ }^{\circ} \mathrm{C}$ un notiek hibridizācija: testsistēmā atrodas vairāki alẹlu paraugi jeb praimeri, kuri piesaistās pie komplementāriem meklējamiem DNS iecirkņiem uz vienķēěu DNS. Tālāk temperatūra tiek paaugstināta līdz vidēji $80{ }^{\circ} \mathrm{C}$. Šajā posmā tiek pievienota DNS-polimerāze (Taq-polimerāze) un nukleotīdi, kuri pagarina DNS fragmentu ar komplementāru praimeru (notiek elongācija) un sintezē tai otru komplementāro DNS ķēedi. Rezultātā no viena DNS fragmenta ar konkrētu gēnu tiek veidota otra kopija, pēc kā abas kḷūst par matricēm nākamajos amplifikācijas ciklos. Meklējamā gēna kopiju skaits pieaug ǵeometriskā progresijā, kas tiek fiksēts ar aparāta palīdzību. Rezultāti tiek nolasīti automātiski uz datora ekrāna gan amplifikācijas programmas izpildes laikā, gan pēc izpildes.

\subsection{TML artrīta piecu soḷu skrīnings}

No 91 pètījuma pacienta daḷai - 64 pacientiem - objektīvā izmeklēšana tika veikta, izmantojot TML artrīta piecu soḷu skrīningu, kas mutiski kā konferences darba grupas rezultāts tika prezentēts 2011. gada TML artrītam veltītā multidisciplinārā konferencē Ķ̣̂̄ē un publicēts 2014. gadā (Koos et al., 2014). N̦emot vērā, ka mūsu pētījums ir sākts 2010. gadā, bet minētais skrīnings publicēts tikai 2014. gadā, tas nav veikts visiem pētîjuma pacientiem.

TML artrīta skrīninga piecu soḷu ilustrāciju sk. 3.2.-3.6. att. 
1. TML palpācija - sāpīga vai nesāpīga (palpācijas laikā mute aizvērta un relaksēta) sk. 3.2. attēlu.

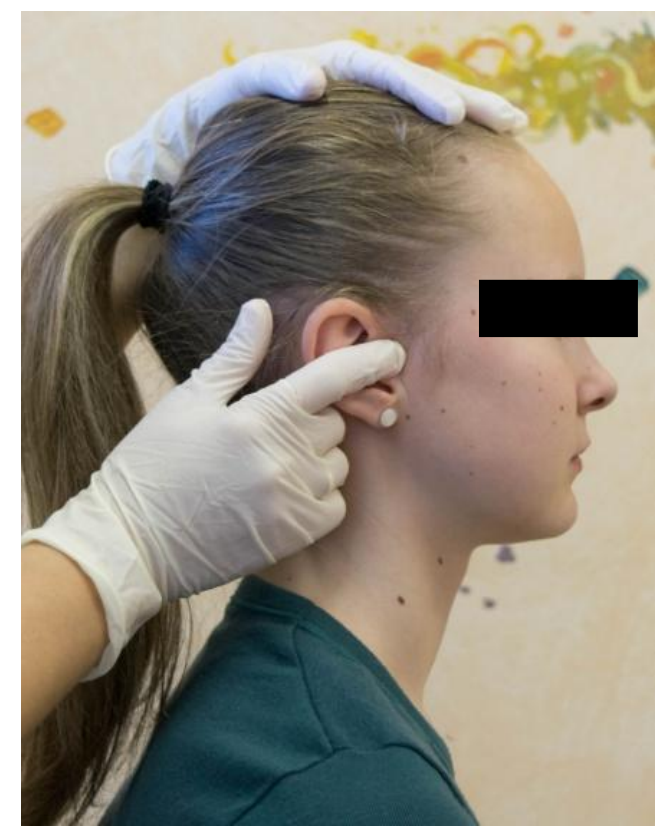

3.2. attēls. TML artrīta skrīnings, 1. solis (foto no personīgā arhīva)

2. Musculus masseter palpācija - sāpīga vai nesāpīga (palpācijas laikā mute aizvērta un relaksēta) - sk. 3.3. attēlu.

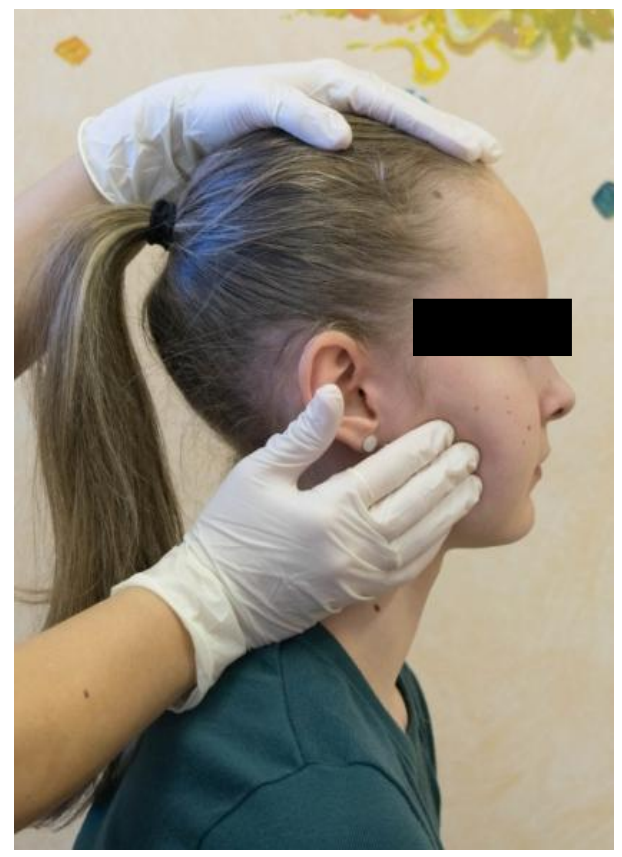

3.3. attēls. TML artrīta skrīnings, 2. solis

(foto no personīgā arhīva) 
3. Musculus temporalis palpācija - sāpīga vai nesāpīga (palpācijas laikā mute aizvērta un relaksēta) - sk. 3.4. attēlu.

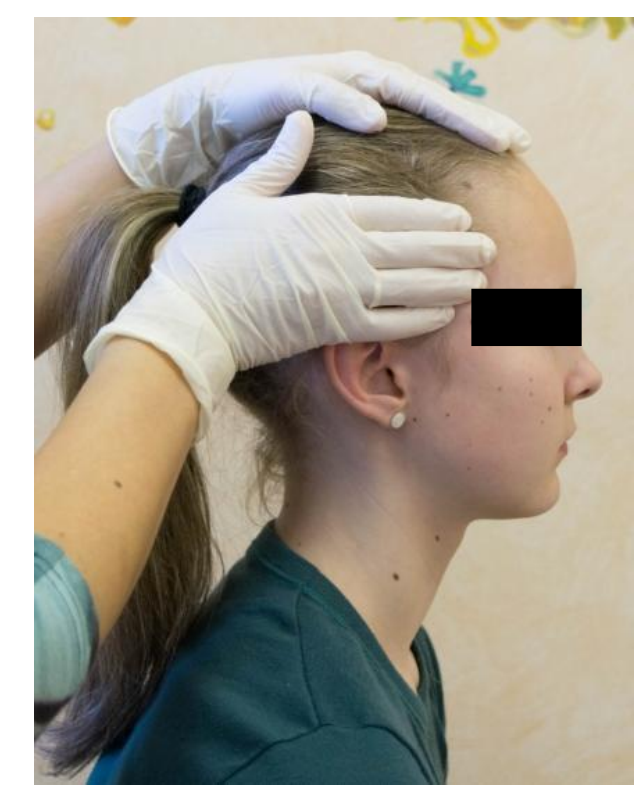

3.4. attēls. TML artrīta skrīnings, 3 . solis

(foto no personīgā arhīva)

4. Mutes atvērums (starp priekšzobiem; pacients pats atver muti, cik plati spēj) sk. 3.5 attēlu:
a) $1 \overline{\mathrm{d}} \mathrm{z} 10$ gadu vecumam $\leq 35 \mathrm{~mm}$ vai normāls;
b) pēc 10 gadu vecuma $\leq 40 \mathrm{~mm}$ vai normāls;
c) atkārtotas vizịtes laikā - vai mutes atvērums samazinājies par $7 \mathrm{~mm}$ vai vairāk;

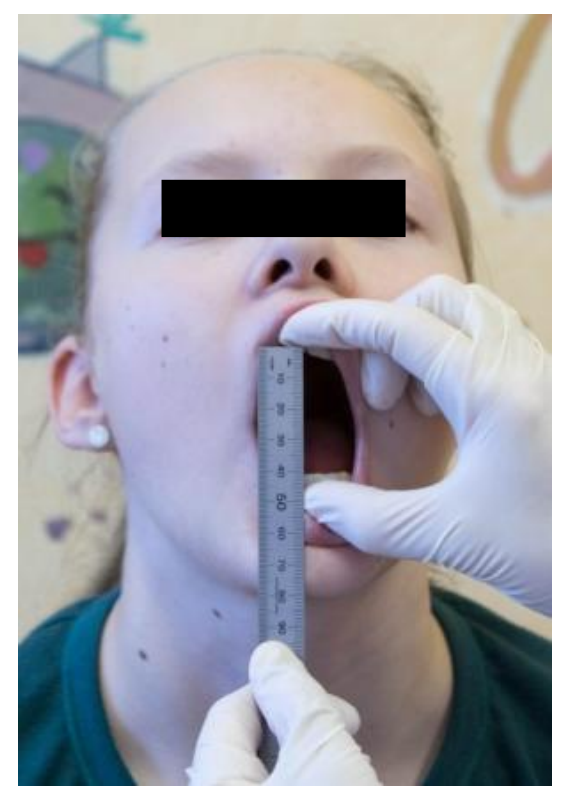

3.5. attēls. TML artrīta skrīnings, 4 . solis (foto no personīgā arhīva) 
5. Maksimāla mutes atvēruma gadījumā apakšžokḷa deviācija ir vairāk par $2 \mathrm{~mm}$ vai norma - sk. 3.6. attēlu.

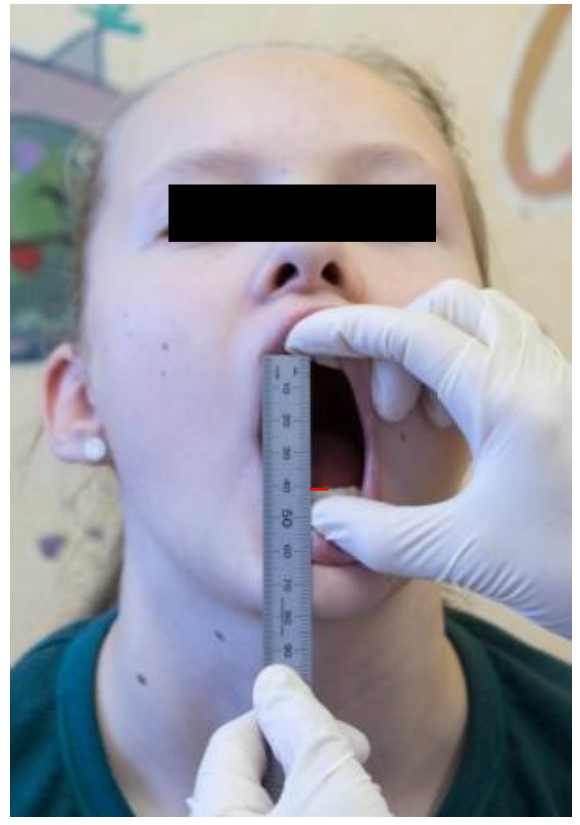

3.6. attēls. TML artrīta skrīnings, 5. solis

(foto no personīgā arhīva)

\subsection{Datu statistiskā analīze}

Datu statistiskā analīze visā pacientu grupā, kā arī salīdzinot MRI pozitīvo un MRI negatīvo grupu, tika veikta, izmantojot IBM SPSS 22.0 programmu. Faktoru izplatību grupās noteica, izmantojot biežuma tabulas. Izplatības biežuma atšķirību statistisko ticamību noteica, izmantojot Pīrsona hī kvadrāta $\left(\chi^{2}\right)$ testu vai Fišera eksakto testu. Par statistiskās ticamības līmeni tika izvēèèta $p$ vērtība $<0,05$.

Alēlu DRB1, DQB1 un DQA1 biežums grupās tika salīdzināts ar Pīrsona hī kvadrāta $\left(\chi^{2}\right)$ kritērija palīdzību. Izredžu attiecības tika aprēḳinātas, izmantojot Kokrana-MantelaHencela procedūru. Izmantojot EPI INFO programmas 6. versiju, tika aprēḳināta P vērtība < 0,05 un OR ar 95\% konfidences intervālu un Fišera korekciju mazām grupām (Harbage, Dean, 1999). Tika aprēḳināts, ka, lai iegūtu vismaz 80\% pētījuma jaudu un ar 5\% ticamības līmeni noteiktu protektīvo OR, pienemot, ka izplatība kontroles grupā ir 70\%, bet pētāmajā grupā 30\%, kontroles grupā jābūt vismaz 18, bet gadījumu grupā - vismaz 36 indivīdiem.

C reaktīvā proteīna rādītāju un eritrocītu grimšanas âtruma salīdzinājumam tika lietots neparametriskais Manna-Vitnija U kritērijs.

TML MRI pozitīvas atrades saistība ar dažādiem demogrāfiskiem, klīniskiem, laboratoriskiem faktoriem tika noteikta, izmantojot logistiskās regresijas modeḷus. 


\section{REZULTĀTI}

\subsection{Pētījumā iekḷauto pacientu demogrāfiskie un slimību raksturojošie rādītāji}

No 91 pētījuma pacienta 64 (70\%) bija meitenes un 27 (30\%) zēni. Vidējais pacientu vecums MRI veikšanas brīdī bija 13,6 gadi ( $\mathrm{SN}=3,1$ gads) (6,0-17,9 gadi). Sadalījums pa JIA tipiem bija šāds: seronegatīvs poliartrīts - 55 pacientiem (60\%), seropozitīvs poliartrīts $7(8 \%)$, persistējošs oligoartrīts $-2(2 \%)$, progresējošs oligoartrīts $-8(9 \%)$, artrīts ar entezītu - 14 (16\%), nediferencēts artrīts - $3(3 \%)$, sistēmisks artrīts - $2(2 \%)$ pacientiem. Nebija neviena pacienta ar psoriātisku artrītu, bet $4(4,4 \%)$ pacientiem tika konstatēts uveîts.

Slimību raksturojošie klīniskie radītāji bija šādi: vidējais slimības ilgums - 3 gadi ( $\mathrm{SN}=2,4$ gadi) $(0,2-11$ gadi), laiks no diagnozes noteikšanas $-1,8$ gadi $(\mathrm{SN}=2,2$ gadi) (0-10 gadi). Vidējais Bērnu veselības novērtējuma aptaujas lapas rezultāts $(C H A Q)$ kopējā JIA slimnieku grupā bija 0,67 punkti $(\mathrm{SN}=1,04)(0-8$ punkti), vidējais sāpju vērtējums pēc vizuālo analogu skalas -4 punkti $(\mathrm{SN}=2)(0-8$ punkti), pacientu vidējais vērtējums par vispārējo labklājību - 4 punkti $(S N=2)(0-10$ punkti), savukārt vidējais ārsta novērtējums par slimības aktivitāti - 5 punkti $(\mathrm{SN}=5)(0-10$ punkti). Vidējais locītavu rīta stīvums ilga 19,7 minūtes ( $\mathrm{SN}=45,1)(0-360$ minūtes). Vidējais aktīvo locītavu skaits, ņemot vērā arī tās locītavas, kurās sinovīts apstiprināts ar USG metodi vai MRI, bija 7 (SN = 5) (0-22 locītavas).

No slimību raksturojošiem laboratoriskiem rādītājiem pozitīivas ANA bija 24 (27,6\%) pacientiem, pozitīvs RF tika konstatēts $6(6,7 \%)$ pacientiem. HLA B27 antigēns bija pozitīvs $18(19,8 \%)$ pacientiem. No iekaisuma rādītājiem, kas raksturo slimības aktivitāti, vidējais CRO bija 5,5 mg/L (SN = 25,08) $(0-180 \mathrm{mg} / \mathrm{L})$, bet EGĀ bija 10,5 mm/h $(\mathrm{SN}=18,62)(0$ 120 mm/h). Slimību raksturojošie rādītāji kopējā pacientu grupā redzami 4.1. tabulā.

4.1. tabula

Slimību raksturojošie rādītāji kopējā pacientu grupā

\begin{tabular}{|l|c|c|c|c|c|}
\hline \multicolumn{1}{|c|}{ Rāīìājs } & $\begin{array}{c}\text { Pacientu } \\
\text { skaits, } \mathrm{n}\end{array}$ & Vidējais & SN & Min. & Maks. \\
\hline Slimības ilgums, gadi & 91 & 3,0 & 2,4 & 0,2 & 11 \\
\hline Laiks no diagnozes noteikšanas, gadi & 91 & 1,8 & 2,2 & 0 & 10 \\
\hline Aktīvo locītavu skaits, $\mathrm{n}$ & 91 & 7 & 5 & 0 & 22 \\
\hline CHAQ & 64 & 0,67 & 1,04 & 0 & 8 \\
\hline VAS - sāpes & 65 & 4 & 2 & 0 & 8 \\
\hline VAS - vispārējā labklājīiba & 65 & 4 & 2 & 0 & 10 \\
\hline
\end{tabular}


4.1. tabulas nobeigums

\begin{tabular}{|l|c|c|c|c|c|}
\hline \multicolumn{1}{|c|}{ Rādītājs } & $\begin{array}{c}\text { Pacientu } \\
\text { skaits, } \mathrm{n}\end{array}$ & Vidējais & SN & Min. & Maks. \\
\hline VAS - ārsta vērtējums & 66 & 5 & 5 & 0 & 10 \\
\hline Rīta stīvums locītavās, minūtes & 89 & 19,7 & 45,1 & 0 & 360 \\
\hline CRO, mg/L & 90 & 5,5 & 25,08 & 0 & 180 \\
\hline EGĀ, mm/h & 91 & 10,5 & 18,62 & 0 & 120 \\
\hline
\end{tabular}

$\mathrm{SN}=$ standartnovirze, Min. = minimālā vērtība, Maks. = maksimālā vērtība.

\subsection{TML artrīta attīstību ietekmējošie faktori}

\subsubsection{Demogrāfiskie, slimību raksturojošie klīniskie un laboratoriskie rādītāji}

Lai noskaidrotu TML artrīta attīstību ietekmējošos faktorus, atkarībā no MRI rezultāta visi JIA pacienti $(\mathrm{n}=91)$ tika iedalīi divās grupās - MRI pozitīvajā grupā $(\mathrm{n}=72)$ un MRI negatīvajā grupā $(n=19)$. Izvērtējot rezultātus MRI pozitīvajā un MRI negatîvajā grupā, tika konstatēts, ka nav statistiski nozīmīgu atšķirību demogrāfiskajos (dzimums un vecums), slimību raksturojošajos klīniskajos (slimības ilgums, laiks no diagnozes noteikšanas, aktīvo locītavu skaits, CHAQ, VAS - pacienta par sāpēm un vispārējā, VAS ārsta par slimības aktivitāti, rīta stīvums locītavās) un laboratorisko rādītāju (EGĀA, ANA, RF, HLA B 27 antigēns) rezultātos (4.2. tabula). Statistiski nozīmīga bija tikai CRP vērtības atšķirība abās grupās: MRI pozitīvajā grupā - pacientiem ar apstiprinātu TML artrītu - vidējā vērtība bija 6,8 (28) mg/L un MRI negatīvajā grupā - 0,3 (0,4) mg/L, p = 0,0078.

4.2. tabula

TML artrīta attīstību ietekmējošie faktori MRI(+), MRI(-) un kopējā JIA slimnieku grupā

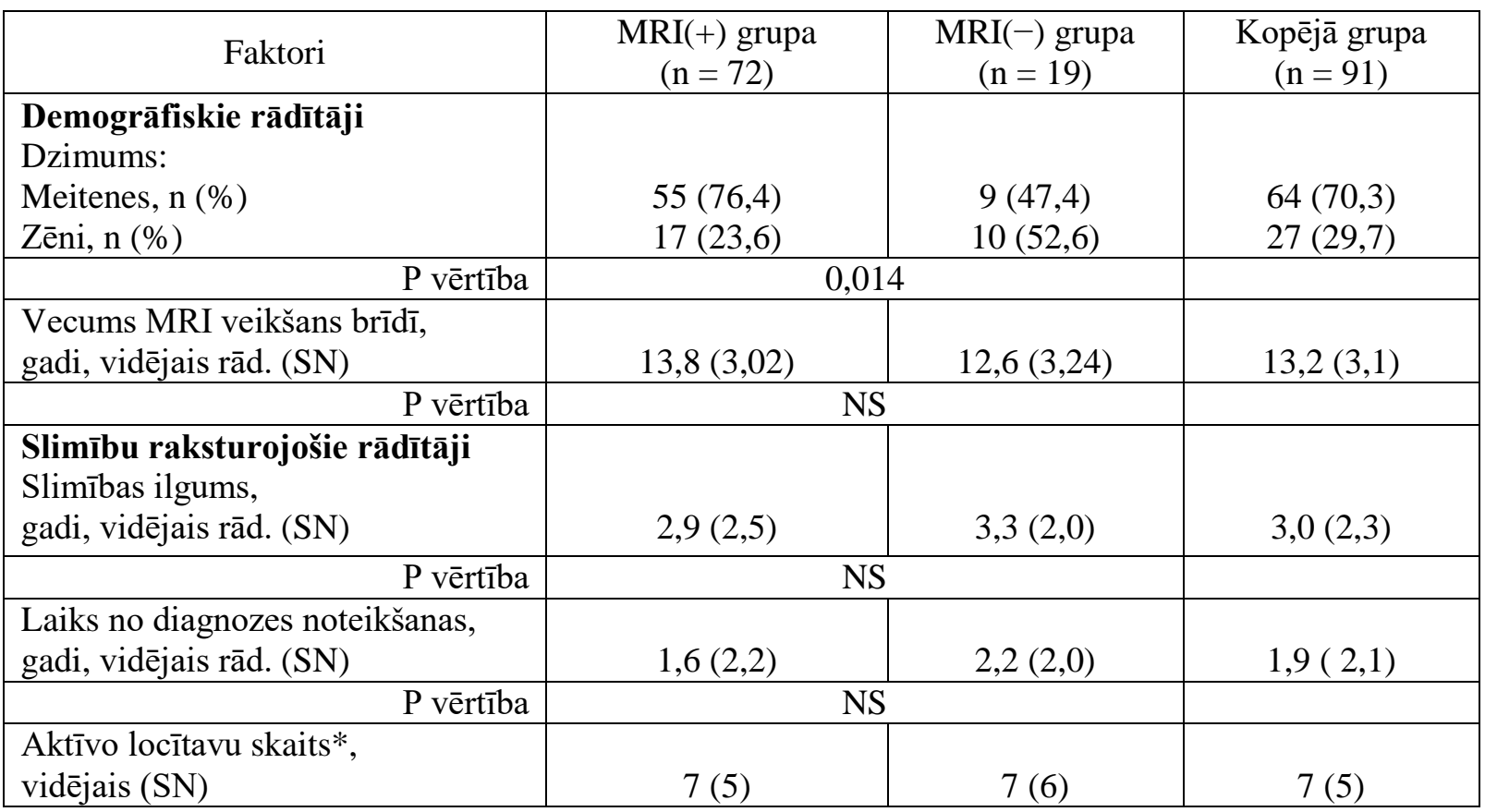


4.2. tabulas turpinājums

\begin{tabular}{|c|c|c|c|}
\hline Faktori & $\begin{array}{l}\text { MRI(+) grupa } \\
\quad(\mathrm{n}=72)\end{array}$ & $\begin{array}{l}\text { MRI(-) grupa } \\
\quad(\mathrm{n}=19)\end{array}$ & $\begin{array}{l}\text { Kopējā grupa } \\
(\mathrm{n}=91)\end{array}$ \\
\hline P vērtība & \multicolumn{2}{|c|}{$\mathrm{NS}$} & \\
\hline$C H A Q$, vidējais (SN) & $\begin{array}{c}0,76(1,13) \\
\mathrm{n}=52\end{array}$ & $\begin{array}{c}0,45(0,47) \\
\mathrm{n}=12\end{array}$ & $\begin{array}{c}0,67(1,04) \\
n=64\end{array}$ \\
\hline $\mathrm{P}$ vērtība & \multicolumn{2}{|c|}{ NS } & \\
\hline VAS - sāpes, vidējais (SN) & $\begin{array}{c}4(2) \\
n=53\end{array}$ & $\begin{array}{c}3(2) \\
\mathrm{n}=12\end{array}$ & $\begin{array}{c}4(2) \\
n=65\end{array}$ \\
\hline$P$ vērtība & \multicolumn{2}{|c|}{ NS } & \\
\hline $\begin{array}{l}\text { VAS - vispārējā labklājība, } \\
\text { vidējais (SN) }\end{array}$ & $\begin{array}{c}4(2) \\
n=53\end{array}$ & $\begin{array}{c}3(2) \\
\mathrm{n}=12\end{array}$ & $\begin{array}{c}4(2) \\
n=65\end{array}$ \\
\hline $\mathrm{P}$ vērtīiba & \multicolumn{2}{|c|}{ NS } & \\
\hline $\begin{array}{l}\text { VAS - ārsta vērtējums, vidējais } \\
\text { (SN) }\end{array}$ & $\begin{array}{c}5(8) \\
\mathrm{n}=54\end{array}$ & $\begin{array}{c}3(1) \\
\mathrm{n}=12\end{array}$ & $\begin{array}{c}5(5) \\
\mathrm{n}=66\end{array}$ \\
\hline P vērtība & \multicolumn{2}{|c|}{ NS } & \\
\hline $\begin{array}{l}\text { Rīta stīvums, minūtes, } \\
\text { vidējais (SN) }\end{array}$ & $\begin{array}{l}21,9(45,0) \\
\mathrm{n}=70\end{array}$ & $\begin{array}{c}11,8(16,8) \\
\mathrm{n}=19\end{array}$ & $\begin{array}{l}19,7(45,1) \\
\mathrm{n}=89\end{array}$ \\
\hline $\mathrm{P}$ vērtība & \multicolumn{2}{|c|}{ NS } & \\
\hline $\begin{array}{l}\text { Laboratoriskie rādīitāji } \\
\mathrm{EG} \bar{A}, \mathrm{~mm} / \mathrm{h} \text {, vidējais }(\mathrm{SN})\end{array}$ & $11,8(20,6)$ & $5,5(5,5)$ & $10,5(18,6)$ \\
\hline$P$ vērtība & \multicolumn{2}{|c|}{ NS } & \\
\hline $\mathrm{CRO}, \mathrm{mg} / \mathrm{L}$, vidējais $(\mathrm{SN})$ & $6,8(28)$ & $0,3(0,4)$ & $5,5(25)$ \\
\hline P vērtība & \multicolumn{2}{|c|}{0,0078} & \\
\hline ANA pozitīvi, n (\%) & $19(26,4)$ & $5(26,3)$ & $24(26,3)$ \\
\hline P vērtība & \multicolumn{2}{|c|}{ NS } & \\
\hline RF pozitīvi, n (\%) & $6(8,3)$ & $0(0)$ & $6(6,6)$ \\
\hline P vērtība & \multicolumn{2}{|c|}{$\mathrm{NS}$} & \\
\hline HLA B27 pozitīvi, n (\%) & $15(20,8)$ & $3(16)$ & $18(19,8)$ \\
\hline $\mathrm{P}$ vērtība & \multicolumn{2}{|c|}{$\mathrm{NS}$} & \\
\hline
\end{tabular}

* Aktīvo locītavu skaits - locītavas ar pietūkumu, kas nav saistīts ar kaulu hipertrofiju, vai kustību ierobežojums un sāpes kustību vai palpācijas laikā. Šajā pētījumā par aktīvām tika uzskatîtas arī locītavas, kurās konstatēts sinovīts ar USG vai MRI metodi arī tajos gadījumos, kad locītava nav aktīva pēc iepriekš minētās definīcijas. NS (non significant) - nav statistiski ticams.

\subsubsection{TML artrīta attīstību ietekmējošās HLA II klases riska un protektīiās alēles}

HLA II klases alēḷ DRB1, DQA1, DQB1 polimorfisms tika analizēts MRI pozitīvajā un kontroles grupā, MRI negatīvajā un kontroles grupā, kā arī savstarpēji MRI pozitīvajā un MRI negatîvajā grupā. MRI pozitīvajā grupā biežāk nekā veselo indivīdu kontroles grupā tika konstatētas šādas alēles: DRB1*07:01 (OR = 7,9, p =0,001), DRB1*11:01 (OR = 2,14, $\mathrm{p}=0,035), \mathrm{DRB} 1 * 13: 01(\mathrm{OR}=2,27, \mathrm{p}=0,022), \mathrm{DRB} 1 * 15: 01(\mathrm{OR}=2,65, \mathrm{p}=0,003)$ un DQB1*05:01 (OR = 1,87, $\mathrm{p}=0,042)$ (sk. 4.3. tabulu). 
HLA II klases alēles, kas JIA slimnieku MRI pozitīvajā grupā sastopamas biežāk nekā veselo indivīdu kontroles grupā

\begin{tabular}{|c|c|c|c|c|c|c|c|c|c|}
\hline \multirow{3}{*}{$\begin{array}{c}\text { HLA II } \\
\text { klases } \\
\text { alēles }\end{array}$} & \multirow{2}{*}{\multicolumn{2}{|c|}{$\begin{array}{l}\text { MRI(+) grupa } \\
(\mathrm{n}=72) \\
\text { Alēlu skaits } \\
(\mathrm{n}=144)\end{array}$}} & \multirow{2}{*}{\multicolumn{2}{|c|}{$\begin{array}{c}\begin{array}{c}\text { Kontroles grupa } \\
(\mathrm{n}=100)\end{array} \\
\text { Alēlu skaits } \\
(\mathrm{n}=200)\end{array}$}} & \multirow{3}{*}{$\chi^{2}$} & \multirow{3}{*}{$\mathrm{p}$} & \multirow{3}{*}{ OR } & \multirow{3}{*}{$\begin{array}{c}\text { OR } \\
95 \% \text { CI }\end{array}$} & \multirow{3}{*}{$\mathrm{P}$} \\
\hline & & & & & & & & & \\
\hline & Abs. & Rel. & Abs. & Rel. & & & & & \\
\hline $\begin{array}{l}\text { DRB1 } \\
* 07: 01\end{array}$ & 20 & 0,14 & 4 & 0,02 & 18,23 & 0,001 & 7,90 & $2,64-23,67$ & 0,001 \\
\hline $\begin{array}{l}\text { DRB1 } \\
* 11: 01\end{array}$ & 20 & 0,14 & 14 & 0,07 & 4,46 & 0,035 & 2,14 & $1,04-4,40$ & 0,038 \\
\hline $\begin{array}{l}\text { DRB1 } \\
* 13: 01\end{array}$ & 21 & 0,15 & 14 & 0,07 & 5,27 & 0,022 & 2,27 & $1,11-4,63$ & 0,024 \\
\hline $\begin{array}{l}\text { DRB1 } \\
* 15: 01\end{array}$ & 27 & 0,19 & 16 & 0,08 & 8,85 & 0,003 & 2,65 & $1,37-5,14$ & 0,004 \\
\hline $\begin{array}{l}\text { DQB1 } \\
* 05: 01\end{array}$ & 27 & 0,19 & 22 & 0,11 & 4,12 & 0,042 & 1,87 & $1,02-3,43$ & 0,045 \\
\hline
\end{tabular}

P $<0,05$. Abs. - absolūtais biežums. Rel. - relatīvais biežums. $\chi^{2}-$ hī kvadrāta kritērijs. OR - izredžu attiecība. CI - ticamības intervāls.

Alēles DRB1*07:01, DRB1*13:01, DRB1*15:01 ir saistītas ar TML artrīta attīstības risku. Alēles DRB1*11:01 un DQB1*05:01 biežāk nekā kontroles grupā tika atrastas arī MRI negatīvajā JIA slimnieku grupā, norādot uz risku saslimt ar JIA, bet nav uzskatāmas par riska alēlēm temporomandibulāro locìtavu artrīta attīstībai (sk. 4.4. tabulu). Arī alēle DRB1*12:01 savukārt biežāk nekā veseliem indivīdiem sastopama MRI negatīvajā grupā $(\mathrm{OR}=2,7$, $\mathrm{p}=0,029)$.

HLA II klases alēles, kas salīdzinājumā ar kontroles grupu biežāk sastopamas MRI negatīvajā JIA pacientu grupā

\begin{tabular}{|c|c|c|c|c|c|c|c|c|c|}
\hline \multirow{3}{*}{$\begin{array}{c}\text { HLA II } \\
\text { klases } \\
\text { alēles }\end{array}$} & \multirow{2}{*}{\multicolumn{2}{|c|}{$\begin{array}{c}\text { MRI(-) grupa } \\
(\mathrm{n}=19) \\
\text { Alēlu skaits } \\
(\mathrm{n}=38)\end{array}$}} & \multirow{2}{*}{\multicolumn{2}{|c|}{$\begin{array}{c}\text { Kontroles grupa } \\
(\mathrm{n}=100) \\
\text { Alēlu skaits } \\
(\mathrm{n}=200)\end{array}$}} & \multirow{3}{*}{$\chi^{2}$} & \multirow{3}{*}{$\mathrm{p}$} & \multirow{3}{*}{ OR } & \multirow{3}{*}{$\begin{array}{c}\text { OR } \\
95 \% \mathrm{CI}\end{array}$} & \multirow{3}{*}{$\mathrm{P}$} \\
\hline & & & & & & & & & \\
\hline & Abs. & Rel. & Abs. & Rel. & & & & & \\
\hline $\begin{array}{c}\text { DRB1 } \\
* 11: 01\end{array}$ & 7 & 0,18 & 14 & 0,07 & 5,18 & $\begin{array}{l}0,02 \\
3\end{array}$ & 3,00 & $1,12-8,02$ & 0,029 \\
\hline $\begin{array}{c}\text { DRB1 } \\
* 12: 01\end{array}$ & 8 & 0,21 & 18 & 0,09 & 4,77 & $\begin{array}{c}0,02 \\
9\end{array}$ & 2,70 & $1,08-6,75$ & 0,034 \\
\hline $\begin{array}{c}\text { DQB1 } \\
* 05: 01\end{array}$ & 9 & 0,24 & 22 & 0,11 & 4,54 & $\begin{array}{l}0,03 \\
3\end{array}$ & 2,51 & $1,05-5,99$ & 0,038 \\
\hline
\end{tabular}

$\mathrm{P}<0,05$. Abs. - absolūtais biežums. Rel. - relatīvais biežums. $\chi^{2}-$ hī kvadrāta kritērijs. OR - izredžu attiecība. CI - ticamības intervāls. 
Alēles, kuras, iespējams, saistītas ar mazāku TML artrīta attīstības risku, biežāk bija sastopamas veselo indivīdu grupā nekā JIA pacientu MRI pozitīvajā grupā - DRB1*08:01 $(\mathrm{OR}=0,05, \mathrm{p}=0,003), \mathrm{DRB} 1 * 16: 01(\mathrm{OR}=0,18, \mathrm{p}=0,001), \mathrm{DRB} 1 * 17: 01(\mathrm{OR}=0,23$, $\mathrm{p}=0,004)$ un $\mathrm{DQB} 1 * 06: 01(\mathrm{OR}=0,12, \mathrm{p}=0,017)(4.5$. tabula $)$.

HLA II klases alēles, kas salīdzinājumā ar veselo indivīdu kontroles grupu JIA pacientu MRI pozitīvajā grupā sastopamas retāk

\begin{tabular}{|c|c|c|c|c|c|c|c|c|c|}
\hline \multirow{3}{*}{$\begin{array}{l}\text { HLA II } \\
\text { klases } \\
\text { alēles }\end{array}$} & \multirow{2}{*}{\multicolumn{2}{|c|}{$\begin{array}{c}\text { MRI pozitīvā } \\
\begin{array}{c}\text { grupa } \\
(\mathrm{n}=72)\end{array} \\
\text { Alēlu skaits } \\
(\mathrm{n}=144)\end{array}$}} & \multirow{2}{*}{\multicolumn{2}{|c|}{$\begin{array}{l}\begin{array}{c}\text { Kontroles } \\
\text { grupa } \\
(\mathrm{n}=100)\end{array} \\
\text { Alēlu skaits } \\
(\mathrm{n}=200)\end{array}$}} & \multirow{3}{*}{$\chi^{2}$} & \multirow{3}{*}{$\mathrm{p}$} & \multirow{3}{*}{ OR } & \multirow[t]{3}{*}{$\begin{array}{c}\text { OR } \\
95 \% \mathrm{CI}\end{array}$} & \multirow[t]{3}{*}{$\mathrm{P}$} \\
\hline & & & & & & & & & \\
\hline & Abs. & Rel. & Abs. & Rel. & & & & & \\
\hline $\begin{array}{c}\text { DRB1 } \\
* 08: 01 \\
\end{array}$ & 0 & 0,00 & 12 & 0,06 & 8,95 & 0,003 & 0,05 & $0,01-0,89$ & 0,041 \\
\hline $\begin{array}{c}\text { DRB1 } \\
* 16: 01 \\
\end{array}$ & 4 & 0,03 & 28 & 0,14 & 12,50 & 0,001 & 0,18 & $0,06-0,51$ & 0,001 \\
\hline $\begin{array}{l}\text { DRB1 } \\
* 17: 01\end{array}$ & 4 & 0,03 & 22 & 0,11 & 8,10 & 0,004 & 0,23 & $0,08-0,69$ & 0,009 \\
\hline $\begin{array}{l}\text { DQB1 } \\
* 06: 01\end{array}$ & 1 & 0,01 & 11 & 0,06 & 5,74 & 0,017 & 0,12 & $0,02-0,94$ & 0,044 \\
\hline
\end{tabular}

$\mathrm{p}<0,05$. $\mathrm{P}<0,05$. Abs. - absolūtais biežums. Rel. - relatīvais biežums. $\chi^{2}-$ hī kvadrāta kritērijs. OR - izredžu attiecība. CI - ticamības intervāls.

Salīdzinot MRI pozitīvo ar MRI negatīvo grupu, netika konstatēta neviena riska alēle; viena no alēlēm bija retāk sastopama pacientiem ar TML artrītu un, iespējams, ar protektīvu nozīmi $-\mathrm{DRB} 1 * 12: 01(\mathrm{p}=0,000, \mathrm{OR}=0,14,95 \% \mathrm{CI}=0,40-0,44)$.

No MRI pozitīvās grupas tika izveidotas divas apakšgrupas - viena grupa ar hroniskām izmaiņām TML $(\mathrm{n}=50)$ un otra grupa, kurā šādu izmaiṇu nebija $(\mathrm{n}=22)$. Pacientiem ar hroniskām izmain̄ām netika atrasta neviena riska alēle, bet tika konstatēts, ka alēles DQA1*05:01 (OR $=042, p=0,042)$ un DQB1*03:01 $(\mathrm{OR}=0,40, \mathrm{p}=0,023)$, iespējams, ir saistītas ar mazāku kaulu strukturālo bojājumu attīstības risku TML (4.6. tabula). Alēle DRB1*11:01, kas iepriekš norādīta kā riska alēle saslimstībai ar JIA kopumā, šajās grupās ir, iespējams, ar protektīvu nozīmi attiecībā pret hronisku izmaiṇu attīstîbu TML (OR $=0,38, \mathrm{p}=0,042)$. Pacientu grupās ar un bez hroniska artrīta pazīmēm slimības ilgums nebija statistiski nozīmīgi atškirīịs - attiecīgi 1,49 $(\mathrm{SN}=2,10)$ un 2,00 gadi $(\mathrm{SN}=2,49)(\mathrm{p}=0,159)$. 
HLA II klases alēlu sastopamība JIA MRI pozitīvajā grupā $(n=72)$ pacientiem ar hroniskām izmaiṇām MRI un bez hroniska iekaisuma pazīmēm

\begin{tabular}{|c|c|c|c|c|c|c|c|c|c|}
\hline \multirow{3}{*}{$\begin{array}{l}\text { HLA II } \\
\text { klases } \\
\text { alēles }\end{array}$} & \multirow{2}{*}{\multicolumn{2}{|c|}{$\begin{array}{c}\text { Pacienti ar } \\
\text { hroniskām } \\
\text { izmain̄ām TML } \\
(\mathrm{n}=50) \\
\text { Alēḷ skaits } \\
(\mathrm{n}=124)\end{array}$}} & \multirow{2}{*}{\multicolumn{2}{|c|}{$\begin{array}{c}\text { Pacienti bez } \\
\text { hroniskām } \\
\text { izmain̄ām TML } \\
(\mathrm{n}=22) \\
\text { Alēlu skaits } \\
(\mathrm{n}=20)\end{array}$}} & \multirow{3}{*}{$\chi^{2}$} & \multirow{3}{*}{$\mathrm{p}$} & \multirow[t]{3}{*}{ OR } & \multirow{3}{*}{$\begin{array}{c}\text { OR } \\
95 \% \mathrm{CI}\end{array}$} & \multirow{3}{*}{$\mathrm{p}$} \\
\hline & & & & & & & & & \\
\hline & Abs. & Rel. & Abs. & Rel. & & & & & \\
\hline $\begin{array}{l}\text { DRB1* } \\
\text { 11:01 }\end{array}$ & 10 & 0,10 & 10 & 0,23 & 4,14 & 0,042 & 0,38 & $0,14-0,99$ & 0,047 \\
\hline $\begin{array}{l}\text { DQA1* } \\
\text { 05:01 }\end{array}$ & 15 & 0,15 & 13 & 0,30 & 4,13 & 0,042 & 0,42 & $0,18-0,98$ & 0,046 \\
\hline $\begin{array}{l}\text { DQB1* } \\
\text { 03:01 }\end{array}$ & 17 & 0,17 & 15 & 0,34 & 5,16 & 0,023 & 0,40 & $0,18-0,89$ & 0,026 \\
\hline
\end{tabular}

$\mathrm{P}<0,05$. $\mathrm{P}<0,05$. Abs. - absolūtais biežums. Rel. - relatīvais biežums. $\chi^{2}-$ hī kvadrāta kritērijs. OR - izredžu attiecība. CI - ticamības intervāls.

\subsection{Subjektīvie un objektīvie klīniskie TML artrīta simptomi un to saistība ar MRI atradi}

No 91 JIA pacientu grupas subjektīvi un/vai objektīvi simptomi saistībā ar TML rajonu tika konstatēti 79 pacientiem. Par vienu pacientu nebija informācijas par viņa subjektīvajām sūdzībām, un vienam pacientam trūka informācijas gan par viṇa subjektīvajām sūdzībām, gan arī par objektīvās izmeklēšanas rezultātiem.

Subjektīvas sūdzības bija 70 pacientiem. No subjektīvajām sūdzībām tika vērtētas biežākās literatūrā aprakstītās sūdzības, kas var būt saistītas ar TML artrītu. Parasti pacienti sūdzējās par sāpēm èdot, dziedot, retāk arī runājot: par kreisās puses locìtavu sāpīgumu sūdzējās 54 (60\%) pacienti, par labās puses - 50 (56\%) pacienti. Krakšḳēěana TML rajonā bija otrā sastopamākā pazīme: kreisajā pusē tā bija 19 (21\%), labajā - 20 (22\%) pacientiem. Sūdzības par galvassāpēm bija 19 (21\%) pacientiem. Par ierobežotu mutes atvērumu sūdzējās 7 (7\%) pacienti. Citi simptomi - klikšḳēěana, TML ieķeršanās sajūta, sāpes un skaņas ausīs, kā redzams 4.1. attēlā - tika konstatēti salīizinoši reti. No ḷoti retajiem simptomiem vienai pacientei tika konstatēts greizais kakls.

Visbiežāk tika konstatēti divi un trīs subjektīvie simptomi - attiecīgi 27 un 18 pacientiem (37\% un 25\% no tiem, kuriem bija subjektīvās sūdzības). Savukārt septiņi un astoṇi simptomi abos gadījumos tika konstatēti tikai vienam pacientam. 


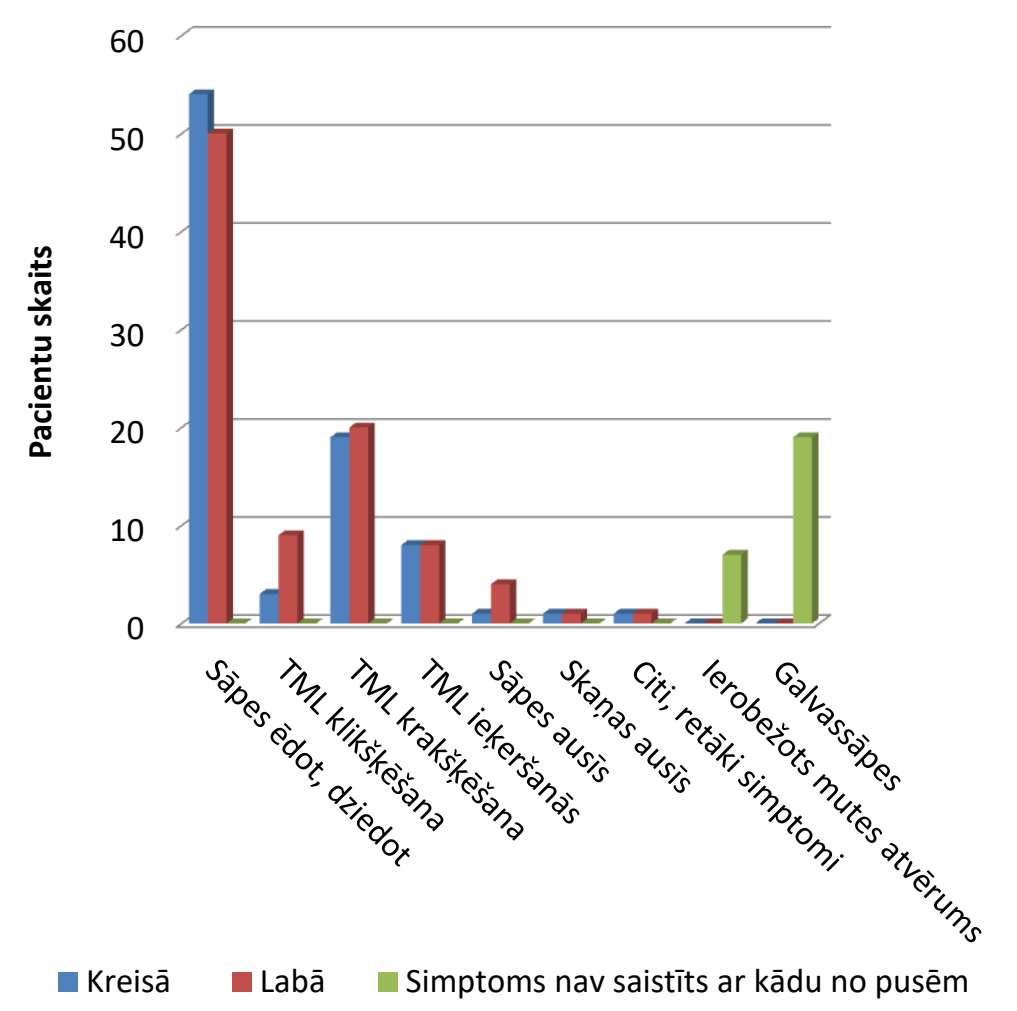

4.1. attēls. JIA kopējās pacientu grupas subjektīvie simptomi

Objektīvie simptomi tika atrasti 74 pacientiem. No kopējās pacientu grupas 16 pacientiem objektīvie simptomi netika atrasti, un 11 no tiem nebija arī subjektīvu simptomu - šie pacienti veido asimptomātisko pacientu grupu, kas tika mērḳtiecīgi atlasīta. Par vienu pacientu nebija objektīvās izmeklēšanas datu.

No objektīvajiem simptomiem visbiežāk tika konstatētas sāpes, palpējot TML 59 (65\%) pacientiem kreisajā pusē, 43 (47\%) pacientiem labajā pusē. Salīdzinoši retāk sāpes palpatori tika konstatētas košanas muskuḷa apvidū - 22 (24\%) pacientiem kreisajā pusē, 14 (15\%) pacientiem labajā; savukārt sāpes, palpējot deniṇu muskuli, bija pavisam reti kreisajā pusē 6 (6\%), labajā pusē - pieciem (5\%) pacientiem. Apakšžokḷa deviācija no viduslīnijas vairāk par $2 \mathrm{~mm}$ pa kreisi tika novērota trijiem (3\%), pa labi - pieciem (5\%) pacientiem. Ierobežots mutes atvērums $(<4 \mathrm{~cm}$ pēc 10 gadu vecuma un $<3 \mathrm{~cm}$ par 10 gadiem jaunākiem bērniem) bija tikai 17 (18\%) pacientiem. Vizuāla apakšžokḷa asimetrija bija vērojama 14 (15\%) pacientiem, savukārt mikrognātija - četriem (4\%) un retrognātija - diviem (2\%) pacientiem. Krepitācija, atverot muti, bija vienam (1\%) pacientam, bet krakšķēšana četriem (4\%) pacientiem (sk. 4.2. attēlu). 


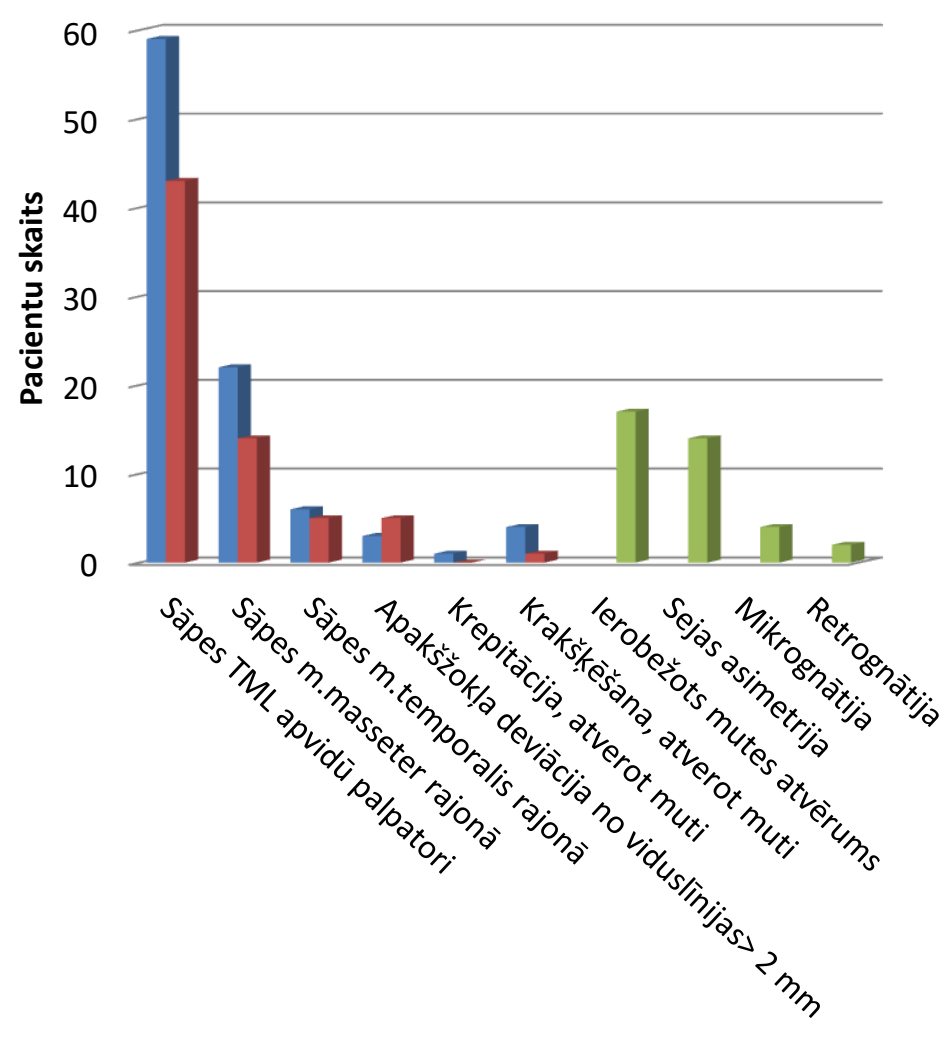

Kreisā $\quad$ Labā $\quad$ Simptoms nav saistīts ar kādu no pusēm

\section{2. attēls. JIA kopējās pacientu grupas objektīvie simptomi}

Subjektīvo simptomu skaits konkrētam pacientam lielākajā daḷā gadījumu nesakrita ar objektīvo simptomu skaitu $(\mathrm{p}=0,001)$. No tiem pacientiem, kuriem bija divas subjektīvas sūdzības, 13 (48\%) pacientiem tika atrasti arī divi objektīvi simptomi; septiṇiem (39\%) pacientiem, kuriem bija trīs subjektīvas sūdzības, atrada divus objektīvus simptomus, bet pieciem (18\%) pacientiem ar divām subjektīvām sūdzībām bija trīs objektīvi simptomi. Lielākajai daḷai pacientu $(n=66,74 \%)$ bija līdz četrām objektīvām un/vai subjektīvām pazīmēm. Bija tikai viens pacients ar astoṇām subjektīvām un astoṇām objektīvām pazīmēm.

No 91 pacientu grupas piecu soḷu TML artrīta skrīnings tika veikts 64 (70\%) pacientiem. Atrasto pazīmju skaits tika salīdzināts ar to pacientu datiem, kuriem tas netika veikts. Vairāk klīniskās pazīmes tika atklātas, veicot skrīningu; piemēram, piecas un astoņas klīniskās pazīmes tika atrastas, tikai izmeklējot TML ar skrīninga palīdzību $(p=0,017)$.

Vidējais subjektīvo sūdzību skaits vienam pacientam MRI pozitīvajā grupā bija 2,3 $(\mathrm{SN}=1,9)$, savukārt MRI negatīvajā grupā - 1,9 $(\mathrm{SN}=1,1), \mathrm{p}=0,327$. Objektīvo pazīmju skaits MRI pozitīvajā grupā bija vidēji $2,3(\mathrm{SN}=1,74)$, MRI negatīvajā grupā -2 (SN = $1,12), \mathrm{p}=0,535$. 
Saistību starp pozitīvu MRI atradi un demogrāfiskajiem, klīniskajiem un laboratoriskajiem faktoriem noteica, izmantojot loǵistiskās regresijas modeli, kurā MRI atrade ir atkarīgais faktors, bet neatkarīgie main̄̄gie lielumi bija dzimums, vecums, CRP, EGĀ, ANA, uveīts, kā arī subjektīvo un objektīvo simptomu skaits. Loǵistiskās regresijas modelī objektīvo simptomu skaits statistiski ticami prognozēja pozitīvu MRI atradi $(\mathrm{p}=0,017$; 95\% TI = 1,16-4,73). Objektīvo simptomu skaitam pieaugot par vienu simptomu, varbūtība, ka MRI atrade būs pozitīva, bija 2,3.

No kopējās pacientu grupas 19 pacientiem MRI nebija aktīva iekaisuma pazīmju, un astoṇiem pacientiem nebija ne subjektīvu, ne objektīvu simptomu, tomēr 11 (57\%) no visiem pacientiem tika konstatēti kaut kāda veida subjektīvi vai objektīvi simptomi.

Subjektīvie un objektīvie simptomi tika analizēti atkarībā no MRI atrades, kas tika sadalīta četrās grupās:

1) pacienti ar aktīvām iekaisuma pazīmēm;

2) pacienti ar aktīvu un hronisku pazīmju kombināciju;

3) pacienti ar izolētām hroniskām pazīmēm;

4) pacienti bez izmaiņām MRI.

MRI atrade JIA slimnieku ( $\mathrm{n}=91)$ grupā bija šāda: $26(29 \%)$ pacientiem tika konstatētas tikai aktīva iekaisuma pazīmes (tostarp arī viegla sinoviāla kontrastēšanās), lielākajai daḷai - 49 (54\%) pacientiem - bija aktīvu un hronisku pazīmju kombinācija, vienam (1\%) pacientam bija izolētas hroniska iekaisuma pazīmes, 14 (16\%) pacientiem netika konstatēta neviena no artrīta pazīmēm (arī ne viegla sinoviāla kontrastēšanās). Tā kā bija tikai viens pacients ar izolētām hroniskām izmaiṇām, dati par šo grupu nav statistiki ticami un tālāk netika analizēti.

Vērtējot subjektīvo un objektīvo simptomu skaitu iepriekš minētajās grupās (izṇemot izolētu hroniska iekaisuma grupu ar vienu pacientu), tika konstatētas statistiski nozīmīgas atšķirīibas: vairāk subjektīvo un objektīvo sūdzību bija grupā ar aktīva un hroniska iekaisuma pazīmju kombināciju. Vidējais subjektīvo sūdzību skaits grupā ar aktīva iekaisuma pazīmēm bija 1,38 (SN = 1,30), grupā ar aktīva un hroniska iekaisuma pazīmju kombināciju tas bija 2,65 ( $\mathrm{SN}=1,90)$, bet grupā bez jebkādām MRI pazīmēm - 1,77 ( $\mathrm{SN}=1,24), \mathrm{p}=0,020$. Objektīvās sūdzības grupā ar aktīva iekaisuma pazīmēm bija 1,46 (SN =1,36), grupā ar aktīva un hroniska iekaisuma pazīmju kombināciju - 2,63 ( $\mathrm{SN}=1,69)$, grupā bez izmaiṇām MRI $1,85(\mathrm{SN}=1,34), \mathrm{p}=0,012$.

Grupā ar aktīvu un hronisku iekaisuma pazīmju kombināciju pacienti biežāk nekā citās grupās sūdzējās par sāpēm ēdot un dziedot; šajā grupā par sāpēm gan kreisajā, gan labajā pusē sūdzējās 29 pacienti (60\% no grupas); savukārt grupā ar aktīvām iekaisuma pazīmēm MRI 
par sāpēm kreisajā pusē sūdzējās 13 (50\%), labajā pusē - 11 (42\%) pacienti. Šādas sūdzības bija arī grupā bez iekaisuma pazīmēm MRI - 10 (77\%) pacienti sūdzējās par sāpēm labajā, astoṇi (61\%) - par sāpēm kreisajā pusē.

Par galvassāpēm sūdzējās 13 (27\%) kombinēto iekaisuma pazīmju grupas pacienti, trīs $(11 \%)$ pacienti aktīva iekaisuma grupā un divi (15\%) pacienti grupā bez iekaisuma pazīmēm MRI.

Krakšķēěanu no kombinētās iekaisuma grupas pacientiem kreisajā pusē atzīmēja 14 (29\%), labajā - 15 (31\%) pacienti, no aktīva iekaisuma grupas - divi (15\%) pacienti kreisajā, viens (8\%) pacients labajā pusē, no grupas bez iekaisuma pazīmēm - divi (15\%) pacienti kreisajā un viens (8\%) pacients - labajā pusē.

Bija arī tādi subjektīvie simptomi, kas sastopami tikai grupā ar aktīva un hroniska iekaisuma kombināciju: TML ieķeršanās sajūta 8 (17\%) pacientiem gan kreisajā, gan labajā pusē; salīdzinoši rets simptoms - sāpes ausīs - kreisajā pusē bija vienam (2\%) pacientam, labajā pusē - četriem (8\%); skaṇas ausīs abās pusēs bija tikai vienam (8\%) pacientam un greizais kakls - arī tikai vienam (8\%) pacientam.

Par ierobežotu mutes atvērumu sūdzējās tikai pacienti abās grupās ar patologiskām izmaiņām MRI: grupāar aktīva iekaisuma pazīmēm - divi (8\%) pacienti un grupā ar aktīva un hroniska iekaisuma kombināciju - 5 (10\%) pacienti.

Statistiski ticami atšķiras tikai ieḳeršanās sajūta TML $(p=0,038)$ (sk. 4.3. attēlu).

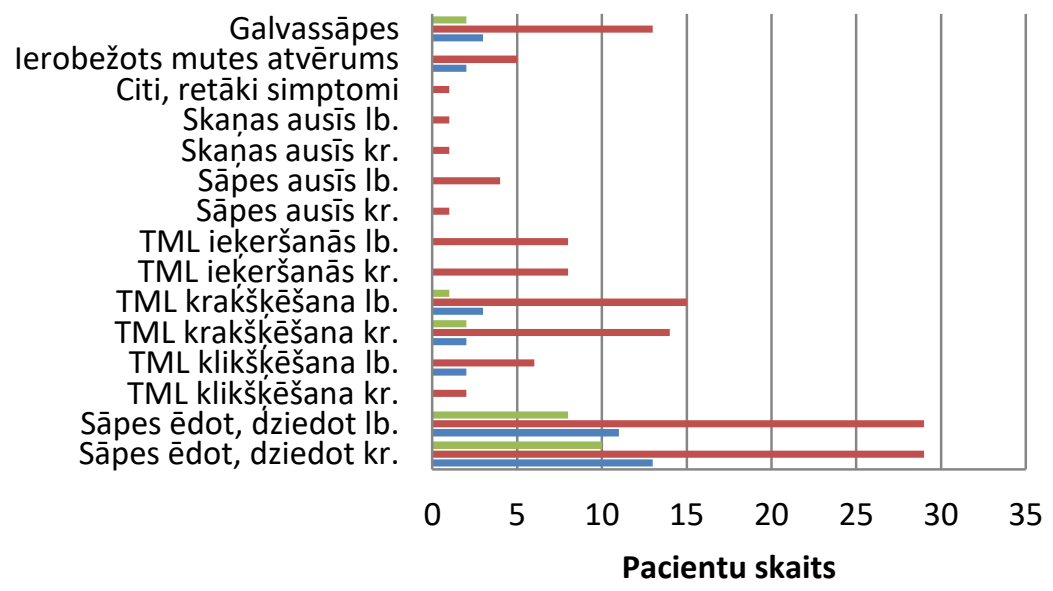

Bez izmaiṇām MRI

Aktīva un hroniska iekaisuma pazīmes MRI

- Izolēts aktīvs iekaisums MRI

4.3. attēls. Subjektīvi simptomi TML pacientu grupās ar aktīva iekaisuma paz̄̄mēm MRI, aktīva un hroniska iekaisuma pazīmēm un bez jebkādām izmaiṇām MRI

(kr. - kreisajā pusēe, lb. - labajā pusē) 
No objektīvajiem simptomiem biežāk tika konstatētas sāpes, palpējot TML: aktīva un hroniska iekaisuma pacientu grupā - 35 (75\%) pacientiem kreisajā un 24 (49\%) pacientiem labajā pusē, izolēta aktīva iekaisuma pacientu grupā - 12 (46\%) pacientiem kreisajā un 10 (38\%) pacientiem labajā pusē, savukārt grupā bez iekaisuma pazīmēm - 10 (77\%) pacientiem kreisajā un $8(61 \%)$ labajā pusē.

Otra biežākā objektīvā atrade bija sāpes m. masseter apvidū palpatori: aktīva un hroniska iekaisuma grupā - 14 (29\%) pacientiem kreisajā un 10 (20\%) labajā pusē; aktīva iekaisuma grupā - 5 (19\%) kreisajā un 3 (11\%) labajā pusē; grupā bez iekaisuma pazīmēm pa $1(8 \%)$ pacientam abās TML pusēs. Pārējie simptomi tika atrasti salīdzinoši retāk, daži no tiem tikai abās grupās ar patoloǵiskām MRI izmaiņām: ierobežots mutes atvērums bija 13 (27\%) pacientiem kombinētā iekaisuma grupā un 4 (15\%) pacientiem aktīva iekaisuma grupā; apakšžokḷa deviācija no viduslīnijas $>2 \mathrm{~mm}$ kreisajā pusē bija $2 \%$ pacientu abās grupās, labajā pusē - 5 (10\%) pacientiem kombinētā iekaisuma grupā.

Daḷa no objektīvajiem simptomiem bija tikai kombinētā iekaisuma pacientu grupā: mikrognātija - četriem (8\%) pacientiem, retrognātija - diviem (4\%) pacientiem, un tikai vienam pacientam bija krepitācija, atverot muti. Statistiski ticamas atškirīibas grupās attiecībā uz objektīvajiem simptomiem atkarībā no MRI rezultāta netika atrastas (sk. 4.4. attēlu). 


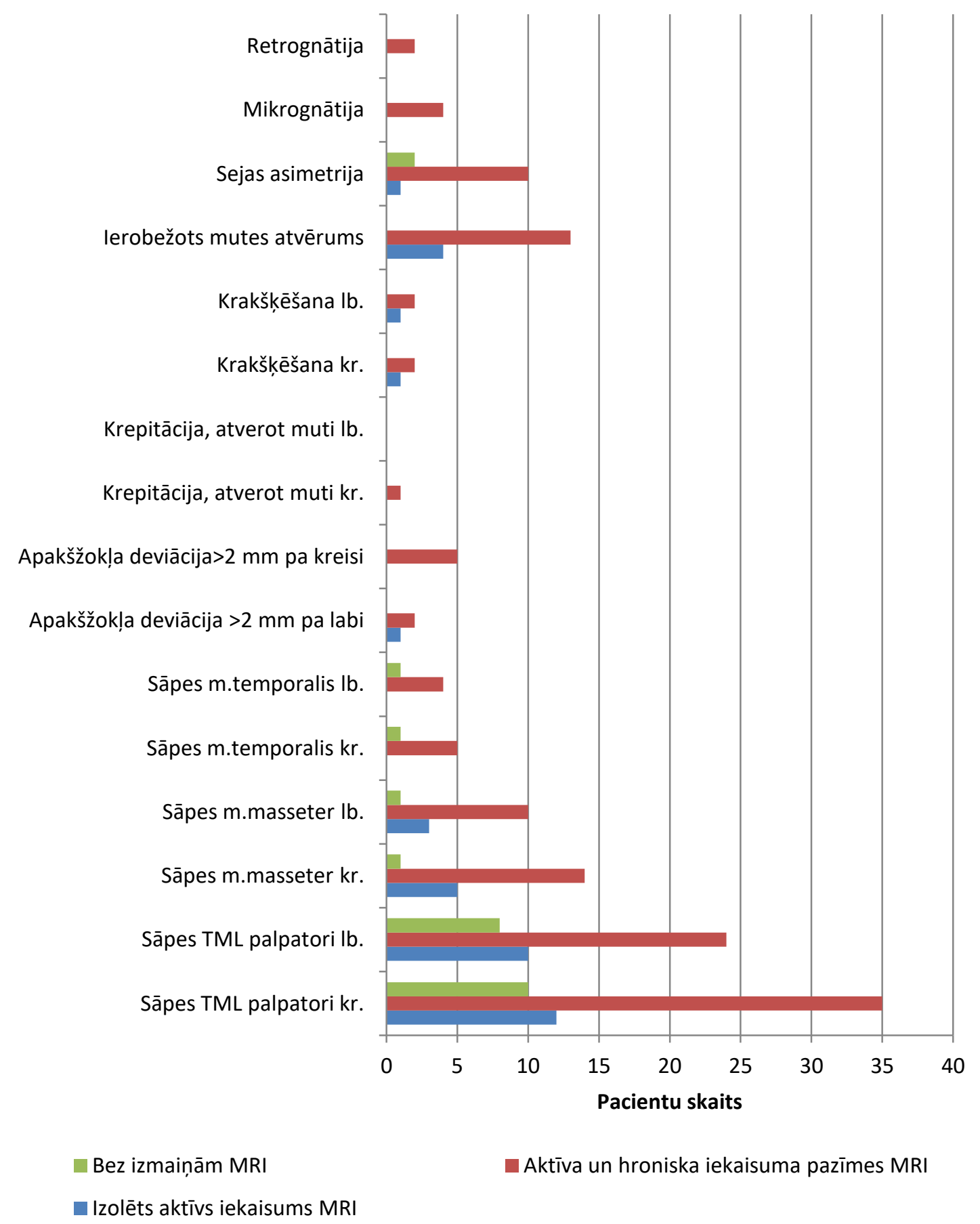

4.4. attēls. Objektīvie simptomi TML pacientu grupā ar aktīva iekaisuma pazīmēm MRI, ar aktīva un hroniska iekaisuma pazīmēm un grupā bez jebkādām izmaiṇām MRI (kr. - kreisajā pusēe, lb. - labajā pusēe). 


\subsection{MRI TML atrade kopējā pacientu grupā, simptomātiskiem un asimptomātiskiem pacientiem}

MRI rezultātus aprakstīja divi radiologi; tika aprēķināts kappa koeficients, lai novērtētu viedokḷu sakritību. Pārsvarā viedokḷu sakritība bija laba, par ko liecina kappa koeficients $k=0,60-0,80$. Atsevišķos gadījumos viedokḷu sakritība bija mērena, piemēram, izvērtējot sinovīta aktivitātes pakāpi skalā no 0 līdz $3(k=0,33)$, kas neietekmēja pacientu dalījumu grupās. Mērena sakritība tika konstatēta gadījumos, kad pazīme ir reti sastopama, piemēram, pannus tika atrasts tikai pieciem pacientiem $(k=0,32)$. Laba viedokḷu sakritība bija kondiḷu galviṇas izvērtēšanas gadījumā, bet vidēja - citu hronisko pazīmju izvērtēšanā $(k=0,40-0,60)$.

Kā minēts iepriekš, no 91 JIA slimnieka grupas 26 pacientiem tika konstatētas tikai aktīva iekaisuma pazīmes, savukārt 14 pacientiem netika atrastas nekādas izmaiņas MRI. N̦emot vērā literatūras datus par iespējamiem normas variantiem, pacienti ar izolētu vieglu sinoviālu kontrastēšanos, kā arī simetriski saplacinātām kondiḷu galviṇām tika iekḷauti MRI negatīvajā grupā. Rezultātā MRI pozitīvajā grupā bija 72 pacienti, bet MRI negatīvajā grupā 19 pacienti.

Lielākoties MRI tika aprakstītas četras pazīmes - 21 pacientam (23\%), 15 (17\%) bērniem nebija nevienas pazīmes, 11 bērniem bija divas un 11 bērniem - sešas pazīmes (12\%). Tikai trijiem JIA pacientiem tika atrasti 10 un vairāk artrīta radiologiskie simptomi.

Detalizēti analizējot aktīvā iekaisuma pazīmes kreisajā un labajā TML pusē, MRI kondiḷu galviṇas tūska tika konstatēta 25 (27\%) pacientiem kreisajā pusē, 17 (18\%) - labajā pusē; izsvīdums locītavas somiņā bija 41 (45\%) pacientam kreisajā pusē, 30 (32\%) pacientiem - labajā pusē. Sinoviāla kontrastēšanās kreisajā locītavā tika atrasta 68 (73\%) pacientiem, bet labajā - 61 (66\%) pacientam, tomēr vidēja vai izteikta sinoviālā kontrastēšanās kreisajā pusē bija tikai 36 (38\%) pacientiem, bet labajā pusē - 25 (27\%) pacientiem. Pannus kreisajā pusē tika konstatēts pieciem (5\%), savukārt labajā pusē - vienam (1\%) pacientam (sk. 4.5. attēlu).

Pacientu grupā ar hroniska iekaisuma pazīmēm MRI atrade bija šāda: kondiļu galviņas deformācija kreisajā pusē bija 42 (46\%), labajā - 30 (33\%) pacientiem; locītavu bedrītes saplacinājums kreisajā pusē - 9 (10\%), labajā - 10 (11\%) pacientiem. Osteofìti kreisajā locītavā tika atrasti pieciem (5\%), labajā - septiṇiem (7\%) pacientiem; erozijas kreisajā pusē bija 21 (23\%), labajā - deviṇiem (10\%) pacientiem (sk. 4.6. attēlu). 


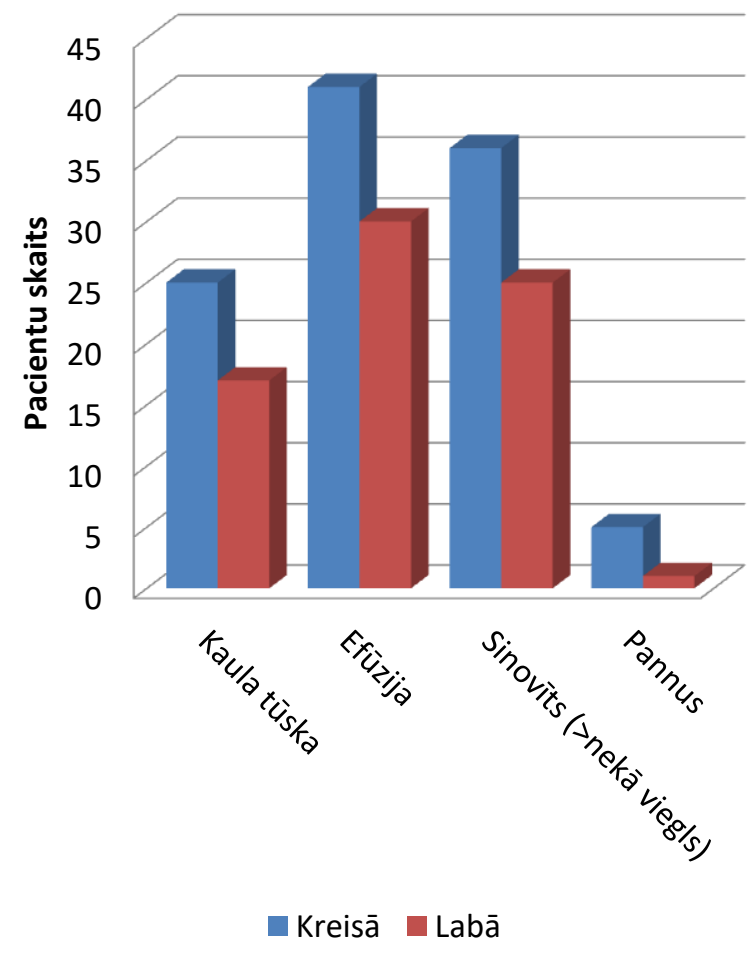

4.5. attēls. Aktīvās iekaisuma paz̄mes - kaulu tūska, efūzija, sinovīts (vairāk nekā viegla sinoviāla kontrastēšānās) un pannuss - TML MRI atrade MRI pozitīvajā pacientu grupā

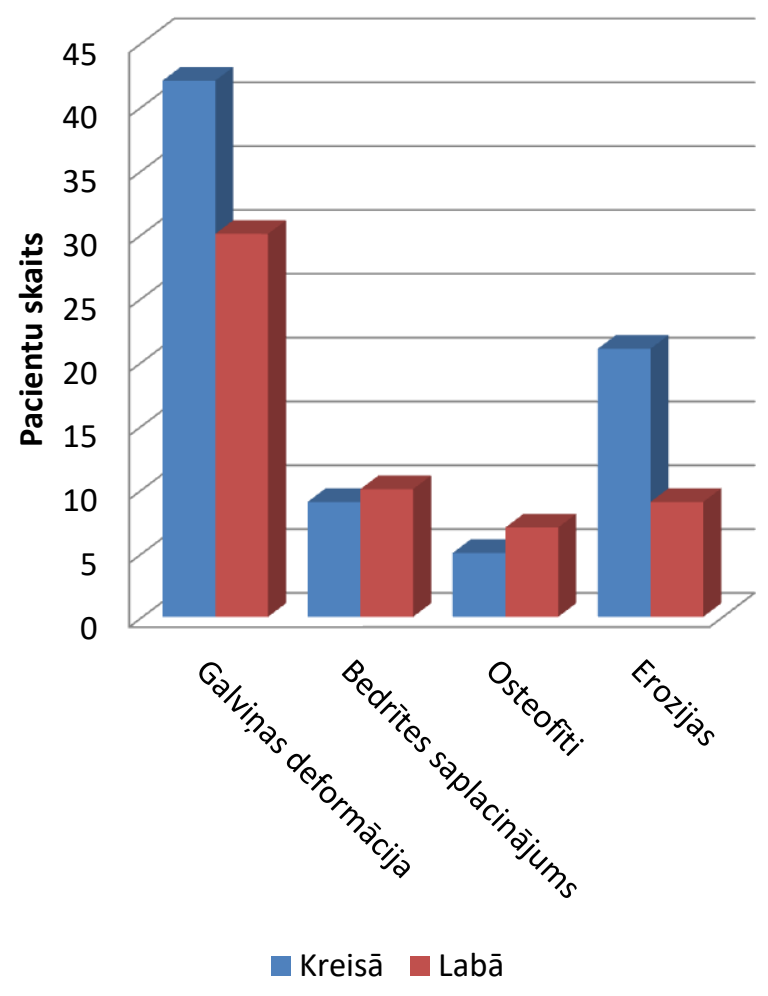

4.6. attēls. Hroniska iekaisuma pazīmju galviṇas deformācijas, bedrītes saplacinājuma, osteofītu un eroziju TML MRI atrade MRI pozitīvajā pacientu grupā 
JIA slimnieku grupā tika iekḷauti 11 pacienti, kuriem netika konstatētas ne subjektīvi, ne objektīvi TML artrīta simptomi (t. i., asimptomātiski pacienti). Lielākajai daḷai pacientu astoṇiem $(73 \%)$ - netika atrastas TML artrīta pazīmes (pieciem pacientiem bija viegla sinoviāla kontrastēšanās, kas uzskatāma par normu), bet tikai diviem (18\%) pacientiem bija pārliecinošas aktīva iekaisuma pazīmes, kas var liecināt par TML artrītu. Vienam pacientam (9\%) bija aktīvu un hronisku pazīmju kombinācija (seši radioloǵiskie simptomi). Nevienam no šīs grupas pacientiem nebija izolētu hroniska artrīta pazīmju. Kopumā pārliecinošas artrīta pazīmes tika atrastas tikai trijiem (27\%) asimptomātiskajiem pacientiem (sk. 4.7. attēlu).
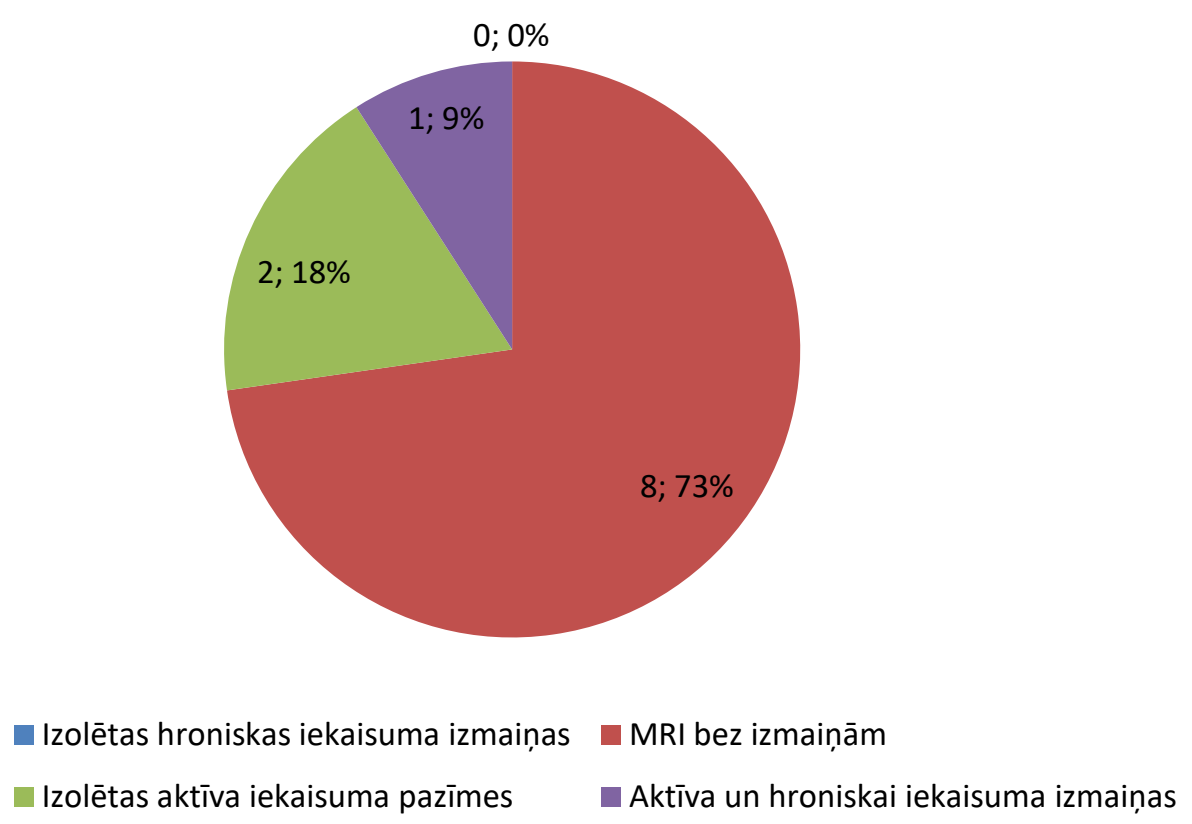

\section{7. attēls. MRI pazīmes asimptomātiskiem JIA slimniekiem}

Analizējot MRI atradi simptomātiskiem JIA slimniekiem $(\mathrm{n}=80)$, lielākajai daḷai no viniiem - $48(60 \%)$ pacientiem - tika atrasta aktīva un hroniska iekaisuma pazīmju kombinācija, 20 (25\%) pacientiem - izolētas aktīva iekaisuma pazīmes, vienam (1\%) pacientam - izolētas hroniska iekaisuma pazīmes, bet $11(14 \%)$ pacientiem MRI patoloğija netika atrasta, kaut gan viṇiem bija vai nu subjektīvi, vai objektīvi simptomi (sk. 4.8. attēlu). 


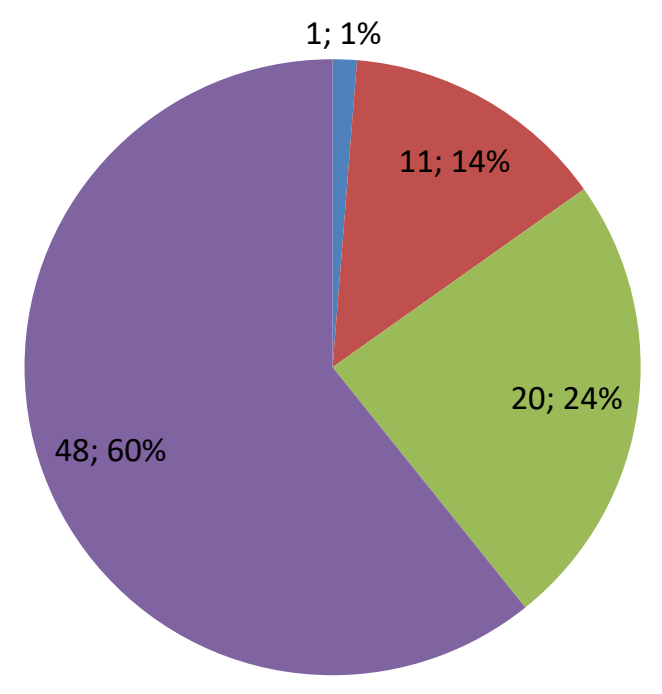

- Izolētas hroniska iekaisuma pazīmes $\quad$ MRI bez izmaināām
Izolētas aktīva iekaisuma pazīmes $\quad$ Aktīva+hroniska iekaisuma pazīmes

4.8. attēls. MRI paz̄̄mes simptomātiskiem JIA pacientiem

Asimptomātisko un simptomātisko pacientu MRI atrades atšķirības, dalot grupās atkarībā no aktīva un hroniska iekaisuma pazīmēm un to kombinācijas, bija statistiski ticamas, $\mathrm{p}=0,003$. Kopumā simptomātisko pacientu grupā bija vairāk pacientu ar aktīva un kombinēta iekaisuma pazīmēm MRI - 48 (61\%), bet asimptomātisko pacientu grupā - tikai viens (9\%) pacients. Salīdzinoši vairāk bija pacientu ar aktīva iekaisuma pazīmēm MRI - attiecīgi simptomātisko pacientu grupā 30 (24\%), bet asimptomātisko pacientu grupā divi (18\%). 


\section{DISKUSIJA}

Pētāmajā grupā bija 91 JIA slimnieks, kuriem laikā no 2010. līdz 2015. gadam veikts TML MRI ar kontrastvielu. Atlasē netika ņemts vērā pacientu vecums, slimības ilgums un JIA tips. Arī līdzšinējos pētījumos par JIA un TML artrītu lielākoties iekḷauti pacienti ar dažādu slimības ilgumu (Müller et al., 2009; Weiss et al., 2008), tomēr ir arī pētījumi, kuros pacientiem TML MRI veikts jau diagnozes noteikšanas brīdī neatkarīgi no sūdzībām vai objektīvās atrades (Cannizarro et al., 2011). Lielākajai daḷai - 98\% pacientu - bija poliartikulāra slimības norise, pārsvarā seronegatīvs poliartrīts $-60 \%$, tomēr pārstāvēti bija arī citi JIA tipi, kam raksturīga poliartikulāra slimības gaita, tai skaitā seropozit̄̄vs poliartrīts, progresējošs oligoartrīts, artrīts ar entezītu, sistēmisks un nediferencēts artrīts. Mūsu pētījuma grupa atspoguḷo to pêtījumu rezultātus, kuros norādīts, ka lielāks risks TML iekaisuma un bojājuma attīstībai ir pacientiem ar poliartikulāru slimības norisi (t. sk. ar progresējošu oligoartrītu, seronegatīvu poliartrītu) (Cannizzaro et al., 2011; Arvidsson et al., 2010).

Mūsu pētījumā meiteņu bija divas reizes vairāk nekā zēnu, kas atbilst literatūrā aprakstìtajiem JIA epidemiologiskajiem datiem, savukārt vidējais vecums - 13,6 gadi - atbilst seronegatīva poliartrīta slimnieku vecuma grupai (Cassidy et al., 2011). N̦emot vērā, ka vidējais aktīvo locītavu skaits bija 7,4, ārsta VAS bija 5 un pacienta VAS 4,4, bet iekaisuma rādītāji pārsvarā bija normas robežās, atbilstoši nacionālajām JIA vadlīnijām pacientu grupas slimības aktivitāte vērtējama kā vidēja, kas tuvāka augstai aktivitātei (Latvijas Pediatru reimatologu asociācija, 2016). Vidējais laiks gados no diagnozes noteikšanas brīža mūsu pacientiem bija 1,8 gadi, kas nozīmēe, ka liela daḷa šo pacientu MRI veikšanas brīdī saṇēma vispārēju terapiju ar metotreksātu, daḷa arī ar biologiiskajiem slimību modificējošiem medikamentiem.

TML artrīta attīstību ietekmējošie faktori tika analizēti, balstoties uz MRI kā zelta standartu TML artrīta diagnostikā, tādēl 91 JIA slimnieki atkarībā no TML artrīta radiologiskajām pazīmēm tika iedalīti MRI pozitīvajā $(n=72)$ un MRI negatīvajā $(n=19)$ grupā. Mūsu pētījumā no iespējamiem TML artrīta attīstību ietekmējošiem demogrāfiskiem (vecums, dzimums), slimību raksturojošiem klīniskiem faktoriem (slimības ilgums, laiks no diagnozes noteikšanas, aktīvo locītavu skaits, CHAQ, VAS pacienta un ārsta, rīta stīvums locītavās) un laboratoriskajiem rādītājiem (EGĀ, CRP, ANA, RF, HLA B27 antigēns) vienīgās statistiski ticamās atškiirības bija CRP rezultātam, kas liecina, ka MRI pozitīvajā grupā vērojama augstāka slimības aktivitāte. Kaut arī nebija statistiski ticamu atšķirību, tomēr jāatzīmē tendence, ka MRI pozitīvajā grupā bija augstāka vidējā CHAQ vērtība, nedaudz augstāki pacienta un/vai vecāku VAS un ārsta VAS vērtējumi, ilgāks rīta stīvums, lielāks 
EGĀ, kā arī visi RF pozitīvie pacienti bija MRI+ grupā. Kopumā tas norāda uz augstāku slimības aktivitāti, kas sakrīt ar citu pētījumu rezultātiem (Argyropoulou et al., 2009; Cannizarro et al., 2011; Steenks et al., 2015).

Vairākos literatūras avotos ir secināts, ka pārliecinošu riska faktoru nav un TML artrīta risks ir visiem JIA slimniekiem neatkarīgi no vecuma, dzimuma, slimības tipa un aktivitātes. Stolls ar kolēgiem 2012. gadā ir publicējis pētījumu ar salīdzinoši lielu kohortu 187 JIA slimniekiem, kuriem laikā no 2007. līdz 2010. gadam veikts MRI (Stoll et al., 2012). Tika noskaidrots, ka gandrīz pusei šo pacientu (43\%) MRI bija TML artrīta pazīmes. Aktīvo locītavu skaits, kā arī citi slimību raksturojošie rādītāji nebija saistīti ar TML artrītu, kā tas novērojams arī mūsu pētījumā. Dažos pētījumos secināts, ka HLA B27 antigēns, iespējams, ir saistīts ar mazāku TML artrīta attīstības risku, taču mūsu pētījumā atšķirīibas MRI+ un MRIgrupā nav statistiski ticamas (Pedersen et al., 2001; Cannizzaro et al., 2011). Savukārt iepriekš pozitīvas ANA atzīmētas kā iespējamais riska faktors (Argyropoulou et al., 2009), kas mūsu pētījumā neapstiprinājās.

Agrīns JIA sākums (līdz četru gadu vecumam) un sistēmisks JIA ir atzīmēti kā TML artrīta riska faktori (Argyropoulou et al., 2009). Šos faktorus mūsu pētījumā nebija iespējams izvērtēt, jo tikai diviem pacientiem bija sistēmiskais artrīts, turklāt pētījuma grupas vidējais vecums bija 13 gadi un jaunākajam pacientam bija seši gadi. Kanizaro un kolēǵi 2005.-2006. gadā pētīja visus slimniekus ar pirmreizēji diagnosticētu JIA neatkarīgi no sūdzībām (Cannizzaro et al., 2011). Tika apsekoti 223 bērni, no kuriem 102 bija veikts TML MRI. Kā riska faktori tika noteikti progresējošs oligoartrīts, seronegatīvs poliartrīts, jaunāks vecums slimības sākumā, lielāks aktīvo locītavu skaits, artrīts augšējās ekstremitātēs, augstāks EGĀ nekā slimniekiem bez TML artrīta slimības sākumā. Mūsu pētījumā varam runāt tikai par tendenci, ka MRI + grupā bija nedaudz lielāks aktīvo locītavu skaits, augstāks EGĀ, taču šie rezultāti nebija statistiski ticami.

Par spīti salīdzinoši nesekmīgiem mēǵinājumiem atrast jelkādus TML artrīta riska faktorus, kā arī ņemot vērā MRI izmaksas un citus ierobežojošus faktorus (vispārējā anestēzija maziem bērniem, iespējama reakcija uz kontrastvielu, breketes), jautājums par to noteikšanu joprojām ir aktuāls (Cannizzaro et al., 2011; Steenks et al., 2015). Tiek meklēti jauni biomarķieri, ar kuru palīdzību varētu monitorēt JIA slimības aktivitāti un līdz ar to arī novērtēt TML artrīta attīstības risku. Viens no tādiem biomarķieriem ir proteīns S100, īpaši S100-A12, kas norāda uz augstāku slimības aktivitāti JIA slimniekiem, tomēr pagaidām nav atsevišķi pētìts pacientiem ar TML artrītu (Consolaro et al., 2015).

Mūsu pētījums apstiprināja hipotēzi, ka TML artrīta attīstību ietekmē ǵenētiski faktori, šajā gadījumā HLA II klases alēles. Veicot HLA II klases alēḷu genotipēšanu un salīdzinot 
rezultātus MRI+ un MRI- grupās, salīdzinot ar veselu indivīdu kontroles grupu, tika konstatēts, ka alēles DRB1*07:01, DRB1*13:01 un DRB1*15:01, iespējams, ir saistìtas ar augstāku TML artrīta attīstības risku, jo bija biežākas MRI+ grupā salīdzinājumā ar kontroles grupu, bet neparādījās kā riska alēles MRI- grupā. Alēles DRB1*11:01 un DQB1*05:01 mūsu pētījumā salīdzinoši biežāk bija sastopamas gan MRI+, gan MRI- grupā, salīdzinot ar kontroles grupu, kas, iespējams, liecina par šīm alēlēm kā riska alēlēm saslimstībai ar JIA kopumā. Šīs alēles parādījās arī vienā no plašākajiem (ar 802 JIA slimniekiem) JIA un HLA II klases alēḷu pētījumiem - Holenbaha pētījumā - šādā JIA riska haplotipā: DRB1*11:01/04:01-DQA1*05:01-DQB1*03:01, kas nebija saistīts ar noteiktu slimības tipu vai saslimšanas vecumu (Hollenbach et al., 2010). Interesanti, ka alēles DRB1*11:01 (mūsu pētījumā riska alēle abās MRI grupās) un DRB1*13:01 (riska alēle MRI+ grupā) tikušas saistītas arī ar lielāku uveīta attīstības risku, ko mūsu pacientu grupā novēroja tikai četriem pacientiem (Angeles-Han et al., 2015).

Hinka pētnieku grupa analizēja 5043 JIA slimniekus, salīdzinot tos ar 14390 kontroles grupas indivīdiem (Hinks et al., 2017). Šajā pētījumā JIA grupā kā biežākā tika novērota DRB1*13:01 alēle, kas mums parādās kā riska alēle TML artrītam, savukārt DRB1*11:01 tika saistīta ar sistēmiska JIA risku (mūsu pētījumā kā riska alēle abās MRI grupās, salīdzinot ar kontroles grupu). TML artrīta riska alēle DRB1*13:01 tiek saistīta arī ar pieaugušo hroniskiem artrītiem - attiecīgi seronegatīvu un seropozitīvu reimatoīdo artrītu (Helm-van Mil et al., 2005). Alēle DRB1*07:01 Apvienotās Karalistes pētnieku publikācijā tiek saistīta ar zemāku persistējoša oligoartrīta risku RF pozitīvam un RF negatīvam poliartrītam un ar entezītu asociētam artrītam, savukārt mūsu pētījumā šī alēle salīdzinājumā ar kontroles grupu atklājas kā iespējama TML artrīta riska alēle. Mūsu pētījuma grupā pārsvarā bija pacienti ar seronegatīvu poliartrītu, bet salīdzinoši maz bija pacientu ar seropozitīvu artrītu vai tādu, kuriem ir artrīts ar entezītu, turklāt nebija neviena pacienta ar persistējošu oligoartrītu, kas daḷēji varētu izskaidrot šīs alēles iepriekš konstatēto nozīmi (Thomson et al., 2002). Meksikas pētnieku grupa šo alēli retāk atrada tieši pacientiem ar seropozitīvu poliartrītu (Silva-Ramirez et al., 2010). Par trešo no TML riska alēlēm - DRB1*15:01 - līdzšinējos pētījumos datu nav.

No riska alēlēm DRB1*12:01 biežāk bija sastopama MRI- grupā, salīdzinot ar veselo indivīdu kontroles grupu, bet neparādījās kā riska alēle MRI+ grupā pret kontroli, kas liecina, ka šì alēle nepasargā no iespējas saslimt ar JIA, tomēr ir protektīva attiecībā uz TML artrīta attīstību. Pētījumos par HLA II klases alēlēm un JIA šì alēle neparādās.

Ar iespējami protektīvu nozīmi mūsu pētījumā izrādījās alēles DRB1*08:01, DRB*16:01, DRB*17:01 un DQB1*06:01. No šìm alēlēm DRB1*08:01 Mureja un kolēǵu pētījumā ir saistīta ar augstāku risku saslimt agrīnā vecumā (Murrey et al., 1999). Kā minēts 
iepriekš, mūsu pacientu vidējais vecums bija 13 gadi, tādēẹ šādā aspektā minēto alēli analizēt nevaram. Par pārējām TML artrīta protektīvajām alēlēm līdzšinējos pētījumos nozīmīgu rezultātu nav. Analizējot MRI pozitīvās un MRI negatīvās grupas klīniskos un laboratoriskos datus, jādomā, ka šīs alēles, iespējams, kopumā pasargā no agresīvākas slimības gaitas, jo MRI negatīvajā grupā CRP bija statistiki ticami zemāks.

Hollenbahs un kolẹǵi secina, ka lielākā daḷa JIA riska un/vai protektīvo alēḷu ir tieši DRB1 (Hollenbach et al., 2010), ko novērojām arī mūsu pētījumā.

Analizējot iespējamās riska un aizsragājošās alēles, kas saistītas ar hronisku izmaiṇu attīstības risku TML, riska alēles mūsu pētījumā netika konstatētas. Alēles DQA1*05:01 un DQB1*03:01 uzrādījās kā iespējami protektīvas hroniskām izmainaām TML jeb strukturāliem kaulu bojājumiem. Interesanti, ka alēle DRB1*11:01, kas iepriekš parādījās kā kopēja JIA riska alēle, šajās grupās izrādījās ar iespējami protektīvu nozīmi. Tomēr jāṇem vērā, ka pacientu skaits minētajās grupās ar $(\mathrm{n}=50)$ un bez $(\mathrm{n}=22)$ hroniskām izmaiṇām ir salīdzinoši mazs. Alēles DQA1*05:01 un DQB1*03:01 grieķu pêtîjumā ir saistītas ar oligoartikulāru slimības gaitu un augstāku uveīta risku, kas varētu liecināt par to, ka pacientiem ar oligoartikulāru slimības gaitu ir mazāks TML artrīta ar paliekošiem strukturāliem bojājumiem attīstības risks (Pratsidou-Gertsi et al., 1999). Pieaugušo hroniska artrīta populācijā ir atrastas HLA II klases alēles - DRB1*01:03, *04:02, *11:02, *11:03, *13:01, *13:02 un *13:04, kas saistītas ar vieglāku slimības gaitu un lēnāku radiologísko bojājumu progresēšanu, no kurām mūsu pētījumā alēle DRB1*13:01 parādās kā TML artrīta riska alēle, taču jārēḳinās, ka bērnu un pieaugušo hroniskie artrīti ir atšķirīgi gan genotipiski, gan fenotipiski (Helm-van Mil et al., 2005).

Kopumā iepriekš minēto alēḷ ietekmi uz TML artrīta attīstību būtu nepieciešams izvērtēt, veicot pētījumu ar lielāku pacientu skaitu, jo mūsu pētījuma pacientu grupā tās nebija sastopamas tik bieži, lai to ietekmi varētu izvērtēt log̣istiskās regresijas modelī.

Lai noskaidrotu, kuriem JIA slimniekiem būtu nepieciešams veikt TML MRI papildus iespējamo TML artrīta attīstību ietekmējošo faktoru noskaidrošanai, detalizēti tika pētītas pacientu subjektīiās un objektīvās sūdzības un to saistība ar MRI atradi gan MRI+ un MRIgrupās, gan arī analizējot sīkāk atkarībā no aktīva un/vai hroniska iekaisuma pazīmēm MRI.

Subjektīvo simptomu noskaidrošanai mūsu pētījumā netika izmantotas speciālas aptaujas anketas, bet no anamnēzes tika fiksētas tādas sūdzības kā sāpes ēdot, dziedot un runājot, galvassāpes, dažādas skaņas ausīs, kā arī citas. Biežākās no subjektīvajām sūdzībām bija sāpes ēdot un dziedot, retāk - arī runājot: kreisajā pusē - 54 (60\%) pacientiem, labajā 50 (56\%) pacientiem. Krakšķēšana TML rajonā bija otra sastopamākā pazīme: kreisajā pusē 19 (21\%), labajā - 20 (22\%) pacientiem. Sūdzības par galvassāpēm bija 19 (21\%) pacientiem, 
bet par ierobežotu mutes atvērumu - tikai 7 (7\%) pacientiem. Pārējās sūdzības bija sastopamas krietni retāk, kas varētu būt skaidrojams ar to, ka pacienti bieži vien neiedomājas, ka, piemēram, sāpes vai skaņas ausīs varētu būt saistītas ar iekaisumu TML. Tiešì šì iemesla dēḷ būtu nepieciešams ikdienas praksē ieviest vienkāršu un īsu aptauju par iespējamām ar TML saistītām sūdzībām. Iespējams, ka šādā gadījumā sūdzību būtu daudz vairāk.

Subjektīvie simptomi arī citos pētījumos biežāk vērtēti, paḷaujoties uz ārsta spēju ievākt detalizētu anamnēzi, retāk - veicot mērḳtiecīgu pacientu anketēšanu (Keller et al., 2015; Müller et al., 2009). Vairākos pêtījumos, kuros analizēta objektīvā pacienta izmeklēšana, subjektīviem simptomiem nav pievērsta liela nozīme (Cannizzaro et al., 2011; Koos et al., 2015; Argyropoulou et al.; 2008; Keller et al., 2015). Kellera un kolēǵu pētījumā minēts, ka subjektīvo sūdzību aptauju veicis ortodonts, kas, iespējams, saistīts ar to, ka reimatologa vizìtē sūdzības ir par dažādām locītavām, tādēl laika trūkuma dēl netiek veikta detalizēta aptauja par vienu konkrētu locītavu, šajā gadījumā - par TML. Stenksa 2015. gada rekomendētajā skrīningā ir iekḷauti pieci jautājumi, kas mērḳtiecīgi būtu uzdodami ikvienam JIA slimniekam (Steenks et al., 2015). Tieši Stenksa pētījums ir viens no retajiem, kurā iekḷauta informācija par subjektīvām sūdzībām; tajā košlāšanas problēmas atzina 10\% pacientu, 14\% pacientu minēja, ka ēd lēnāk nekā citi, savukārt sāpes, ēdot cietu barību, bija $14 \%$ pacientu, un par ierobežotu mutes atvērumu sūdzējās $11 \%$ pacientu.

Mūsu pētījumā ir dati par vispārējo sāpju līmeni, atsevišḳki neizdalot sāpes TML. Vidējais VAS rādītājs par sāpēm mūsu pacientiem MRI+ grupā bija nedaudz augstāks - 4 nekā MRI- grupā - 3, tomēr nebija statistiski ticami atšķirīgs. Kellera pētījumā par sāpēm TML sūdzējās 37\% pacientu, un vidējais sāpju līmenis bija 3,3 (0-7). Sāpju līmenis šajā pētījumā vērtējams kā zems, kas apstiprina arī citu pētījumu rezultātus par sāpēm kā rādītāju ar zemu sensitivitāti un specifitāti TML sinovīta un deformācijas diagnostikai (Keller et al., 2015; Twilt et al., 2004). Jāatzīmēe, ka praksē biežāk izmantotajā juvenila idiopātiska artrīta slimnieku veselības aptaujā (CHAQ) un sāpju skalā TML problēmas netiek atspoguḷotas.

Analizējot objektīvo atradi, sāpes TML mūsu pacientiem bija biežākā atrade (65\% pacientu kreisajā pusē un 47\% - labajā), sāpes košanas muskuḷu apvidū bija otrais biežākais no objektīvajiem simptomiem (24\% pacientu kreisajā, 15\% - labajā pusē), pārējie simptomi - sāpes deniṇu muskuḷu apvidū, apakšžokḷa deviācija, krepitācija, krakšķēšana, ierobežots mutes atvērums, sejas asimetrija, mirkognātija un retrognātija - bija ievērojami retāki.

Ierobežots mutes atvērums atbilstoši vecuma normai tika konstatēts tikai 17 (18\%) mūsu pacientiem. Abramovičs un kolēgi secinājuši, ka samazināts mutes atvērums 6,7 reizes palielina sinovīta atrades risku MRI (Abramowitz et al., 2013). Kellera pētījumā secināts, ka 
samazināts mutes atvērums liecina par jau deformētiem apakšžokḷa kondiḷiem, tādēḷ nav izmantojams TML artrīta agrīnā diagnostikā (Keller et al., 2015.).

Mūsu pētījumā apakšžokḷa deviācija no viduslīnijas vairāk par $2 \mathrm{~mm}$ tika novērota tikai astoņiem pacientiem. Stolls un pētnieku grupa konstatēja, ka no klīniskajiem objektīvajiem simptomiem visspēcīgākā asociācija ar TML artrītu ir tieši šim simptomam (Stoll et al., 2012). Salīdzinot objektīvās izmeklēšanas rezultātus ar MRI rezultātiem, Koss secināja, ka vissensitīvākā $(0,65)$ un specifiskākā $(0,78)$ TML artrīta pazīme ir asimetriska mutes atvēršana, izmeklējot pacientu objektīvi, kam sekoja sāpes, palpējot TML (sensitivitāte 0,61, specifitāte 0,71) un košanas muskuluus (sensitivitāte 0,40, specifitāte 0,86) (Koos et al., 2014). Šiem rezultātiem vajadzētu mudināt reimatologus vairāk uzmanības pievērst tādam simptomam kā asimetriska mutes atvēršana pacientiem ar JIA.

Mūsu pētījumā 70\% pacientu tika veikts TML artrīta skrīnings (Koos et al., 2014), kas palielināja iespēju atrast vairāk objektīvo pazīmju. Tas ir būtiski, ņemot vērā pētījumus, kas liecina, ka vairāku objektīvu pazīmju kombinācija paaugstina izmeklēšanas sensitivitāti piecu rādītāju kombinācijas sensitivitāte ir 0,85, specifitāte 0,54 (Twilt et al., 2004; Koos et al., 2014). Attiecībā uz objektīvo izmeklēšanu primārās aprūpes speciālistiem ieteiktais pGALS skrīnings ietver tikai daḷēju TML izmeklēšanu, savukārt bērnu reimatologu lietotā reimatoloǵiskā izmeklēšana, kas ietver 71 locītavas sāpju, kustību ierobežojumu un pietūkuma izvērtēšanu, neietver deniņu un košanas muskuḷu palpāciju, kā arī apakšžokḷa deviāciju, kas nozīmē to, ka reimatologu ikdienas praksē papildus būtu ieviešams TML artrīta skrīnings (Foster, Jandial, 2013; Bousnaki, Koidis, 2015).

Dažādos pētījumos objektīvo simptomu novērtēšana ir bijusi atšḳirīga, un tikai pēdējos gados vadošie speciālisti ir vienojušies par salīdzinoši vienkāršu skrīningu, kas būtu izmantojams ne tikai ortodonta, bet arī reimatologa praksē (Koos et al., 2014; Steenks et al., 2015). Stinksa pētījumā, kurā izmantots subjektīvo sūdzību un objektīvās izmeklēšanas skrīnings, no objektīvajiem simptomiem biežākie bija sāpes, atverot muti (18\%), samazināts mutes atvērums (12\%), retāk krepitācija (5\%) un apakšžokḷa deviācija (7\%). Šie simptomi arī mūsu pacientiem tika novēroti salīdzinoši reti (sk. iepriekš). Stinksa skrīningā nebija iekḷauta košanas un deniņu muskuḷu palpācija, savukārt mūsu pacientiem palpatori sāpīgi košanas muskuḷi bija otrais biežākis simptoms aiz palpatori sāpīgām TML.

Koss ar kolēgeiem ir pētījis klīnisko simptomu saistību ar MRI rezultātiem 134 JIA slimniekiem (Koos et al., 2014). Šajā pētījumā, atšķirībā no Stinksa pētījuma, objektīvā izmeklēšana bija komplicētāka un iekḷāva TML klikšķēěanu, atverot muti, TML jutīgumu, košanas muskuḷu - m. masseter un m. temporalis - jutīgumu, samazinātu vai asimetrisku mutes atvērumu. Interesanti, ka šajā pētījumā tika veikta salīdzināšana ar veselu indivīdu 
kontroles grupu un tika konstatēts, ka samazināts mutes atvērums abās grupās ir sastopams vienlīdz bieži, kas iepriekšējos pētījumos norādīts kā būtisks simptoms iespējamam apakšžokḷa kondiḷu bojājumam (Argyropoulou et al., 2009; Arabshahi \& Cron, 2006).

Mūsu pētījumā 11/19 (57\%) pacientiem bija kāds subjektīvs vai objektīvs simptoms, kas varētu liecināt par TML artrītu, tomēr MRI atbilde bija negatīva. Iespējams, ka šajos gadījumos pacientu sūdzības un objektīvā atrade TML ir saistīta ar citām iespējamām TML patologijāàm, tostarp miofasciālo sāpju sindromu (Abramowicz et al., 2013). Ma un kolēǵu pētījumā klīniskie simptomi, kas varētu būt saistīti ar TML artrītu, piemēram, sāpes TML apvidū, samazināts mutes atvērums un krepitācija, tika konstatēti 32/48 (67\%) pacientiem ar aktīvām iekaisuma izmaiṇām MRI un arī 5/19 (21\%) pacientiem bez iekaisuma pazīmēm MRI (Ma et al., 2015).

Būtiski, ka subjektīvo un objektīvo simptomu skaits mūsu pētījumā pacientiem statistiski ticami bija lielāks grupā ar aktīva un hroniska iekaisuma pazīmju kombināciju, kas apstiprina citu pētījumu datus, ka tieši strukturālās izmaiņas TML biežāk manifestējas ar simptomiem nekā izolētas aktīvas izmaiṇas (Keller et al., 2015).

Mūsu pētījumā logistiskās regresijas modelī salīdzinoši MRI+ un MRI- grupā tika analizēti dažādi demogrāfiskie, klīniskie un laboratoriskie rādītāji, kā arī subjektīvo un objektīvo simptomu skaits. Tika konstatēts, ka objektīvo simptomu skaits statistiski ticami prognozē pozitīvu MRI atradi, kas liecina par to, cik svarīga ir objektīvā izmeklēšana, izvērtējot, vai pacientam nepieciešams veikt MRI. To apstiprina arī citi pētnieki. Kristensens un kolēgi uzskata, ka klīniskajai izmeklēšanai nākotnē ir nozīmīga loma TML artrīta diagnostikā, tomēr tai jābūt strukturētai un vienotai, kā arī nepieciešami prospektīvi pētījumi, kuros tiek analizēta šo simptomu korelācija ar MRI atradi (Kristensen et al., 2016). Ir uzskats, ka klīniskie objektīvie simptomi ir samērā specifiski, bet nepietiekami sensitīvi TML artrītam (Koos et al., 2014). Mohameds un kolẹǵi apstiprina, ka klīniskie objektīvie simptomi atškirīibā no subjektīvajiem simptomiem spēcīgi korelē ar MRI atradi (Mohammed et al., 2012).

Jānem vērā, ka mūsu pētījumā objektīvos simptomus vērtēja reimatologi, savukārt vairākos līdzšinējos pētījumos ir salīdzināti reimatologu un ortodontu izmeklēšanas rezultāti, kas atšḳiras (Keller et al., 2015; Müller et al., 2009). Pacienti ar JIA būtu jānovēro ne tikai reimatologam, bet arī ortodontam, jo katram no šiem speciālistiem ir savas kompetences izmeklēšanā, kuras kombinējot var iegūt detalizētāku informāciju (Steenks et al., 2015; Keller et al., 2015). Attiecībā uz subjektīvo un objektīvo simptomu saistību ar MRI atradi apstiprinās citu pētījumu rezultāti, kas liecina, ka, pat kombinējot dažādus objektīvus simptomus un panākot salīdzinoši augstāku izmeklēšanas sensitivitāti, nav iespējams atklāt visus TML artrīta gadījumus, kurus apstiprina MRI atrade (Koos et al., 2014). 
Iespēja izmeklēt TML ar MRI ir būtiski mainījusi priekšstatu par š̄is locītavas iekaisumu un bojājumu JIA slimniekiem, jo devusi iespēju atklāt agrīnas iekaisuma radītas izmaiņas (Küseler et al., 1998; Müller et al., 2009). Mūsu pētījuma norises laikā no 2010. līdz 2015. gadam pakāpeniski ir mainījusies un attīstījusies izpratne par to, kā vērtēt TML MRI rezultātus. Līdz ar to rezultātu interpretācijā rodas grūtības, kas saistītas ar to, ka JIA gadījumā jāvērtē locītava, kas vēl attīstās un ar ko saistītas dažādas pazīmes, kas, iespējams, vērtējamas kā norma, piemēram, ir konstatēts, ka simetrisks kondiḷu galviņas saplacinājums var būt normas variants, kā arī tas, ka viegla simetriska sinoviālo apvalku kontrastēšanās sastopama arī bērniem, kam nav JIA (Kalle et al., 2013; Moe et al., 2016; Arvidsson et al., 2009). Kḷūdas ir iespējamas arī sakarā ar to, ka TML attēlu MRI ietekmē daudz apkārtējo audu, kas var nomaskēt tādas pazīmes kā mīksto audu tūsku, izsvīdumu locītavas somin̄ā un arī periartikulāru osteopēniju (Sheybani et al., 2013.). Iepriekš minēto pētījumu rezultāti tika ņemti vērā, analizējot MRI mūsu pētîjumā.

Lai adekvāti novērtētu MRI rezultātu, pirmkārt, jārēḳinās ar to, ka MRI attēla vērtējums ir subjektīvs. Mūsu pētījumā viedokḷu sakritība tika noteikta ar kappa koeficientu. Kappa koeficients vairumā gadījumu bija 0,6-0,8, kas liecina par labu viedoklu sakritību. BKUS radiologu viedokḷi vairāk atšḳīrās, vērtējot tieši hroniskās iekaisuma pazīmes.

Kellera pētījumā minēts, ka MRI aprakstu veikuši divi radiologi un vienojušies par gala slēdzienu, tomēr nav norādīts kappa koeficients (Keller et al., 2015). Līdzīgi arī Ma un kolēǵu pētījumā teikts, ka MRI aprakstījuši divi radiologi ar vairāk nekā 5 un 10 gadu pieredzi, tomēr detalizētākas informācijas nav (Ma et al., 2015). Vaids un kolēgei ir centušies izveidot TML MRI izvērtēšanas skalu, lai sistematizētu MRI aprakstus. Pētījumā divi radiologi analizējuši MRI attēlus un konstatējuši, ka akūto pazīmju vērtēšanā kappa koeficients ir 0,51, savukārt hronisko izmaiṇu vērtēšanā 0,68 , bet visbiežāk nesaskaņas bija par izsvīdumu locītavas dobumā, kur viedokḷi sakrita tikai $38 \%$ gadījumu, kas atšḳiras no mūsu rezultātiem, kur viedokḷu atškirības vairāk tika novērotas hronisko iekaisuma pazīmju vērtēšanā (Vaid et al., 2014).

Mūsu pētījumā 72 (79\%) pacientiem tika konstatētas artrīta pazīmes TML, bet jāṇem vērā, ka lielākajai daḷai (88\%) pacientu MRI tika veikts sakarā ar to, ka bija kādas subjektīvas un/vai objektīvas TML artrīta paz̄̄mes. Lielākajai daḷai mūsu pacientu - 49 (53\%) - tika konstatētas gan aktīva, gan hroniska iekaisuma pazīmes, bet hroniska iekaisuma pazīmes (izolēti vai kombinācijā ar aktīvām iekaisuma pazīmēm) bija 50 (55\%) pacientiem. No aktīva iekaisuma pazīmēm visbiežāk tika konstatēts izsvīdums locītavas somiṇā - attiecīgi 41 (45\%) pacientam kreisajā, bet 30 (32\%) pacientiem labajā pusē, otra biežākā atrade bija sinoviāla kontrastēšanās (izolēta viegla sinoviāla kontrastēšanās netika uzskatīta par artrīta pazīmi) - 
kreisajā pusē 36 (38\%), bet labajā 25 (27\%) pacientiem. Visbiežākā hroniska iekaisuma pazīme bija kondiḷu galviṇas deformācija - kreisajā pusē 42 (46\%), bet labajā 30 (33\%) pacientiem, savukārt otra biežākā atrade bija erozijas - 21 (23\%) pacientam kreisajā, 9 (10\%) pacientiem labajā pusē.

Musslera un kolēǵu pētījumā 34 JIA slimniekiem 2010. gadā konstatēts, ka biežākā aktīva artrīta pazīme ir sinoviālo apvalku kontrastēšanās - 76\% pacientu, tomēr nav precizēts, cik izteikta kontrastēšanās šiem pacientiem novērota, respektīvi, vai tā uzskatāma par patologisku. Kellers un pētnieku grupa veica MRI 76 JIA slimniekiem neatkarīgi no sūdzībām un objektīvās izmeklēšanas rezultātiem. Tika vērtēts izsvīdums, pastiprināta sinoviāla kontrastēšanās un apakšžokḷa kondiḷu deformācijas. Šiem pacientiem tika veikta arī reimatolog̣iska un ortodontiska izmeklēšana, kas tika salīdzināta ar MRI datiem. TML artrīta pazīmes bija 71\% izmeklēto pacientu, 68\% pacientu bija aktīva iekaisuma paz̄̄mes, tika arī precizēts, ka sinoviālā kontrastēšanās, kas bija biežākā aktīva iekaisuma pazīme, kā viegla tika vērtēta 67 locītavās, bet tikai 18 locītavās kā izteikta. 33\% pacientu tika konstatēta kondiḷu deformācija (Keller et al., 2015).

Koss un kolēǵi pētījumā ar 134 JIA slimniekiem, kas tika iekḷauti pētījumā neatkarīgi no simptomiem, TML artrītu konstatēja $80 \%$ pacientu, kas ir augsts prevalences rādītājs (Koos et al., 2014). Argiropaulu un kolēgi 2009. gadā publicēja pētījumu par 46 JIA slimniekiem 2-36 gadu vecumā, kurā, analizējot 88 TML, 32\% pacientu tika konstatētas patoloǵiskas kondiḷu izmaiṇas, 27\% - saplacināta locītavas bedrīte, 17\% - saplacināts locītavas disks, 10\% - intraartikulārs šķidrums, 45\% - pannus (Argyropoulou et al., 2009). Jāṇem vērā, ka, salīdzinot ar mūsu pētījumu, vecuma grupa bija ḷoti plaša, tādēḷ rezultāti nav salīizināmi.

Mūsu pētījuma rezultāti apstiprina citu pētījumu datus, ka TML artrīts bieži sastopams klīniski asimptomātiskiem JIA slimniekiem, tomēr parāda, ka MRI atrade, analizējot aktīvās un hroniskās iekaisuma izmaiṇas, asimptomātiskiem pacientiem ir salīdzinoši vieglāka nekā simptomātiskiem, kuriem vairāk novēro aktīva iekaisuma un hroniska locītavas bojājuma pazīmju kombināciju. No 11 asimptomātiskajiem pacientiem astoņiem tika konstatētas kaut kāda veida izmaiņas MRI, tomēr pieciem pacientiem bija tikai viegla sinoviāla kontrastēšanās, kas pētîjumā ar pacientiem, kuriem MRI galvai un TML veikts ar JIA nesaistītu iemeslu dēl, tiek minēta kā iespējams normas variants (Von Kalle et al., 2012). Tikai vienam pacientam bija aktīvu un hronisku izmaiṇu kombinācija MRI atradē, bet diviem pacientiem - pazīmes, kas var liecināt par aktīvu TML artrītu, respektīvi, tikai 27\% asimptomātisko pacientu bija izmaiņas MRI, kas prasa terapijas pārskatīšanu, iespējams, pat taktikas maiṇu. Simptomātisko pacientu grupā lielākajai daḷai $(60 \%)$ tika konstatēta aktīva un hroniska iekaisuma pazīmju 
kombinācija, kas daḷēji sasaucas ar literatūras datiem, jo tieši strukturālas izmaiņas locītavā biežāk nekā izolētas aktīva iekaisuma pazīmes rada kādus simptomus (Keller et al., 2015). Interesanti, ka 11 simptomātiskajiem pacientiem MRI bija bez izmaināam, kas norāda uz to, ka simptomi, kurus uzskatām par iespējamām TML artrīta pazīmēm, var norādīt uz citām TML patologijāām, iespējams, arī uz miofasciālo sāpju sindromu, kā tas konstatēts pētījumā ar 61 JIA slimnieku, no kuriem deviņiem bija sāpes TML un apkārtējos muskuḷos palpatori, tomēr radiologiski TML artrīta diagnoze netika apstiprināta (Abramowicz et al., 2013).

Reimatologi un bērnu reimatologi pēdējos gados daudz diskutē par remisijas definīciju JIA slimniekiem. Tiek apsvērts, ka, lai slimniekam noteiktu remisiju, būtu nepieciešams kombinēt klīnisko, imunolog̣isko un arī radiologisko izmeklējumu rezultātus. Aktuāls ir jautājums par to, ar kādām metodēm un kuras locītavas būtu nepieciešams pārbaudīt, lai definētu remisiju (Brown et al., 2012; Sheybani et al., 2013). Mūsu pētījuma rezultāti liecina, ka TML varētu būt vienas no tām, kurām, diagnosticējot remisiju un atceḷot terapiju, būtu jāpievērš īpaša uzmanība, sevišķi gadījumos, kad slimniekam iepriekš konstatēts TML artrīts.

Mūsu pētījuma rezultāti ir aktuāli un svarīgi TML diagnostikā, jo, kā apstiprina Feldevari un kolēǵu 2014. gadā publicētais pētījums, taktika dažādos centros l̦oti atšksiras. Tika analizēta dažādās valstīs (87 centros) praktizētā pieeja TML artrīta diagnostikai un terapijai no 2009. līdz 2010. gadam (Foeldvari, Tzaribachev, Cron, 2014). TML artrīta skrīningam visos centros tiek veikta objektīiā izmeklēšana, bet tikai $88 \%$ centru tos veica visiem JIA pacientiem jau pirmajā vizịtē neatkarīgi no tā, vai pacientam ir sūdzības saistībā ar TML; 97\% centru mērḳtiecīgi aptaujāja slimniekus par iespējamiem TML artrīta simptomiem, bet tikai 3\% centru veica radioloǵisko skrīningu ar MRI. No radiologisiskajiem izmeklējumiem TML artrīta diagnostikai tikai 77\% centru veica MRI, 10\% centru - USG, 9\% - CT, 33\% konvencionālo rentgenogrāfiju. Lielākā daḷa centru (65\%) pozitīvas atrades gadījumā izvēlējās veikt intraartikulāras injekcijas. Kaut arī pētījumi liecina par MRI kā par zelta standartu TML artrīta diagnostikā (Argyropulou et al., 2009; Pedersen et al., 2008; Weiss et al., 2008), minētie rezultāti rāda, ka daudzviet pasaulē to nav iespējams realizēt visiem JIA pacientiem, bet gan tikai tiem, kam subjektīvā un objektīvā atrade liecina par iespējamu TML artrītu.

Ṇemot vērā literatūras datus, kā arī mūsu pētījuma rezultātus, visiem JIA slimniekiem būtu jāizvērtē TML artrīta risks. Mūsu pētījuma rezultāti pārsvarā ir attiecināmi uz pusaudžu vecuma pacientiem (vidējais vecums 13 gadi) ar JIA poliartikulāru gaitu, tomēr pētījumi liecina, ka risks ir pacientiem visās JIA grupās (Stoll et al., 2012). Īpaša vērība būtu jāpievērš pacientiem ar augstu slimības laboratorisko aktivitāti, īpaši paaugstinātu CRP. Svarīgi ir praksē ieviest kādu no vienkāršiem skrīningiem TML subjektīvo un objektīvo simptomu 
izvērtēšanai. Šobrīd tāds varētu būt mūsu pētījumā iekḷautais piecu soḷu TML skrīnings, kas papildināts ar konkrētiem jautājumiem no anamnēzes, kas savukārt precizēti Stinksa pētījumā (Steenks et al., 2015). Lai iegūtu precīzāku objektīvās izmeklēšanas informāciju, visus JIA slimniekus vajadzētu nosūtīt pie ortodonta (Keller et al., 2015; Müller et al., 2009).

HLA II klases riska alēles nākotnē varētu tikt iekḷautas pacientu standarta izmeklēšanas plānā, tomēr līdz tam būtu nepieciešama sīkāka to pacientu, kuriem ir šīs konkrētās alēles, izpēte ilgākā laika posmā.

MRI ar kontrastvielu ir uzskatāms par zelta standartu TML artrīta agrīno izmaiṇu diagnostikā, tomēr, ņemot vērā, ka uzskati par normu un patoloǵiju augošā locītavā pastāvīgi mainās, šaubu gadījumā, kad no MRI rezultāta ir atkarīga tālākā ārstēšanas taktika, būtu nepieciešams atkārtoti izvērtēt MRI rezultātu, iespējams, piesaistot otru radiologu.

Hipotēze par dažādu faktoru ietekmi uz TML artrīta attīstību apstiprinājās daḷēji TML artrīta attīstību neietekmē demogrāfiski, slimību raksturojošie klīniskie faktori, bet gan iekaisuma laboratoriskā aktivitāte - paaugstināts CRP, kā arī genētiskie faktori - konkrētas HLA II klases alēles. Rezultāti apstiprināja hipotēzi, ka objektīvie un subjektīvie simptomi ir saistīti ar MRI atradi un liecina, ka pacienta objektīvai izmeklēšanai diagnostikā ir nozīmīga loma. 


\section{SECINĀJUMI}

1. Pêtījuma pacientu kopējā grupā meiteņu ir divas reizes vairāk nekā zēnu. Vidējais vecums atbilst pusaudžu vecuma bērniem. Lielākā daḷa pacientu ir ar poliartikulāru slimības gaitu, pārsvarā seronegatīvu poliartrītu. Kopumā slimību raksturojošie klīniskie rādītāji (aktīvo locītavu skaits, CHAQ, pacientu un ārsta VAS, rīta stīvums locītavās) un laboratoriskie rādītāji (EGĀ, CRP) liecina, ka pacientu grupa atbilst vidēji aktīvai slimībai.

2. No TML artrīta attīstību ietekmējošiem faktoriem - demogrāfiskiem, slimību raksturojošiem klīniskiem un laboratoriskiem rādītājiem - paaugstināts CRP ir ticami saistīts ar risku attīstīties TML artrītam. Pārējie faktori - demogrāfiskie (dzimums un vecums), klīniskie (slimības ilgums, laiks no diagnozes noteikšanas, aktīvo locītavu skaits, $C H A Q$, ārsta un pacientu VAS rezultāti, rīta stīvums locītavās) un laboratoriskie (EGĀ, ANA, HLA B27 antigēns) rādītāji - pacientu grupās ar TML artrītam atbilstošu MRI atradi un bez artrīta pazīmēm statistiski ticami neatšķiras.

TML artrīta attīstību pacientiem ar juvenilu idiopātisku artrītu ietekmē genētiski faktori. HLA II klases alēles - DRB1*07:01, DRB1*13:01, DRB1*15:01 - ir saistītas ar TML artrīta attīstības risku. Pacientiem ar alēlēm DRB1*08:01, DRB1*16:01, DRB*17:01 un DQB1*06:01 ir zems TML artrīta attīstības risks. Alēles DRB1*11:01, DQA1*05:01 un DQB1*03:01 ir saistītas zemu kaulu strukturālo bojājumu attīstības risku TML.

3. Subjektīvo un objektīvo simptomu skaits MRI pozitīvajā un MRI negatīvajā grupā statistiski ticami neatšķiras, bet statistiski ticamas ir atškirības pacientu grupās atkarībā no detalizētāka MRI rezultāta sadalījuma (pacienti ar izolēta aktīva iekaisuma pazīmēm, aktīva un hroniska iekaisuma pazīmēm, izolēta hroniska iekaisuma paz̄̄mēm un bez pazīmēm). Gan subjektīvo, gan objektīvo simptomu skaits ir lielāks grupā ar aktīva un hroniska iekaisuma pazīmju kombināciju. Loǵistiskās regresijas analīze pierāda, ka, pieaugot objektīvo simptomu skaitam par vienu simptomu, pozitīvas MRI atrades varbūtība palielinās 2,3 reizes. No atsevišķiem subjektīviem simptomiem statistiski ticama atšķirība ir "ieķeršanās” sajūtai TML, kas raksturīga pacientiem ar aktīva un hroniska iekaisuma pazīmēm MRI. Statistiski ticami atšķirīgu objektīvo simptomu minētajās pacientu grupās nav.

4. JIA slimniekiem ar subjektīviem un/vai objektīviem TML artrīta simptomiem MRI statistiski ticami biežāk konstatē aktīva un hroniska iekaisuma kombināciju, savukārt JIA slimniekiem, kuriem nav subjektīvu un/vai objektīvu TML artrīta simptomu, MRI atrade biežāk ir bez patoloǵijas vai ar vieglu sinoviālu kontrastēšanos, kas uzskatāma par normas variantu. 


\section{PRAKTISKĀS REKOMENDĀCIJAS}

Visiem JIA slimniekiem jāveic mērktiecīga aptauja attiecībā uz subjektīviem TML artrīta simptomiem, kā arī TML artrīta objektīvo simptomu skrīnings ar piecu soḷu testu (sk. sadaḷā "Metodes" un 3.1.-3.5. attēlus).

JIA slimniekiem, kuriem tiek konstatētas divas subjektīvas un/vai objektīvas pazīmes, rekomendē veikt TML MRI ar kontrastvielu.

Ja pacientiem ar JIA un vismaz vienu subjektīvu un/vai objektīvu simptomu konstatē paaugstinātu CRP līmeni, rekomendē veikt TML MRI ar kontrastvielu. 


\section{PERSPEKTĪVIE TURPMĀKO PĒTĪJUMU VIRZIENI}

JIA slimniekiem būtu mērķtiecīgi jānosaka pētījumā atrastās HLA II klases riska alēles DRB1*07:01, DRB1*13:01, DRB1*15:01, lai noskaidrotu detalizētu šo slimnieku profilu, kas ietvertu slimības gaitu, klīnisko un laboratorisko aktivitāti, TML un citu locītavu iesaistīšanos. Perspektīvāa ar šo alēḷu palīdzību varētu prognozēt slimības gaitu, TML un citu locītavu iesaistǐšanās risku un atbilstoši tai izvēlēties medikamentozo terapiju. 


\section{IZMANTOTĀ LITERATŪRA}

1. Abramowicz S., Susarla H. K., Kim S., Kaban L. B. Physical findings associated with active temporomandibular joint inflammation in children with juvenile idiopathic arthritis. Journal of Oral and Maxillofacial Surgery, 2013; 71(10): 1683-1687. doi:10.1016/j.joms.2013.04.009. Epub 2013 Aug 8.

2. Abramowicz S., Kim S., Susarla H. K., Kaban L. B. Differentiating arthritic from myofascial pain in children with juvenile idiopathic arthritis: preliminary report. Journal of Oral and Maxillofacial Surgery, 2013; 71: 493-496.

3. Ahmad M., Schiffman E. L. Temporomandibular joint disorders and orofacial pain. Dental Clinics of North America, 2016; 60: 105-124.

4. Alomar X., Medrano J., Cabratosa J., Clavero J. A., et al. Anatomy of temporomandibular joint. Seminars in Ultrasound Ct and MRI, 2007; 28: 170-183.

5. Al-Shwaikh H., Urtane I.,Pirttiniemi P., Pesonen P., Krisjane Z., Jankovska I., Davidsone Z., Stanevica V. Radiologic features of temporomandibular joint osseous structures in children with juvenile idiopathic arthritis. Cone beam computed tomography study. Stomatologija, 2016; 18(2): 51-60.

6. Altman D. G. Practical statistics for medical research. New York, NY: Chapman \& Hall/CRC Press, 2011.

7. Angeles-Han S., McCracken C., Yeh S., Yang S. R., et al. HLA associations in a cohort of children with juvenile idiopathic arthritis with and without uveitis. Investigative Ophthalmology \& Visual Science, 2015; September, 56: 604-6048.

8. Arabshahi B., Cron R. Q. Temporomandibular joint arthritis in juvenile idiopathic arthritis: the forgotten joint. Current Opinion Rheumatology, 2006; 18(5): 490-495.

9. Arabshahi B., Dewitt E. M., Cahill A. M., et al. Utility of corticosteroid injections for temporomandibular arthritis in children with juvenile idiopathic arthritis. Arthritis \& Rheumatism, 2005; 52: 3363-3569.

10. Argyropoulou M. I., Margariti P. N., Karali A., et al. Temporomandibular joint involvement in juvenile idiopathic arthritis: clinical predictors of magnetic resonance imaging signs. European Radiology, 2009; 19: 693-700.

11. Arvidsson L. Z., Fjeld M. G., Smith H. J., Flatø B., Ogaard B., Larheim T. A. Craniofacial growth disturbance is related to temporomandibular joint abnormality in patients with juvenile idiopathic arthritis, but normal facial profile was also found at the 27-year follow-up. Scandinavian Journal of Rheumatology, 2010; 39(5): 373-379. doi: $10.3109 / 03009741003685624$.

12. Arvidsson L. Z., Flatø B., Larheim T. A. Radiographic TMJ abnormalities in patients with juvenile idiopathic arthritis followed for 27 years. Oral Surgery, Oral Medicine, Oral Pathology, Oral Radiology and Endodontology, 2009 Jul; 108(1): 114-123. doi: 10.1016/j.tripleo.2009.03.012.

13. Arvidsson L. Z., Smith H. J., Flatø B., Larheim T. A. Temporomandibular joint findings in adults with long-standing juvenile idiopathic arthritis: CT and MR imaging assessment. Radiology, 2010 Jul; 256(1): 191-200.

14. Assaf A. T., Kahl-Nieke B., Feddersen J., Habermann C. R. Is high-resolution ultrasonography suitable for the detection oftemporomandihular joint involvement in children with juvenile idiopathic arthritis? Dentomaxillofacial Radiology, 2013; 42: 20110379.

15. Bousnaki M., Koidis P. Temporomandibular joint - the neglected joint of children with juvenile idiopathic arthritis. IOSR Journal of Dental and Medical Sciences, 2016; 15(12): 105-114.

16. Brown A., Hirsh R., laor T. et al., Do patients with juvenile idiopathic arthritis in clinical remission have evidence of persistent inflammation on 3T magnetic resonance imaging. Arthritis Care and Researh, 2012; 64(12): 1846-1854.

17. Carvalho R. T., Braga F. S. F. F., Brito F., Capelli J., Fugueredo C. M., Sztajnbok F. R. Temporomandibular joint alterations and their orofacial complications in patients with juvenile idiopathic arthritis. Revista Brasileira de Reumatologia, 2012; 52: 903-907.

18. Cassidy J. T., Petty R. E., Laxer R. M., Lindsley C. B. Textbook of Pediatric Rheumatology. Sixth ed. Philadelphia: Saunders, 2011, 212-213, 223, 251. 
19. Cannizzaro E., Schroeder S., Müller L. M., Kellenberger C. J., Saurenmann R. K. Temporomandibular joint involvement in children with juvenile idiopathic arthritis. The Journal of Rheumatology, 2011; 38(3): 510-515.

20. Consolaro A., Giancane G., Schiappapetra B., Davi S., Calandra S., Lanni S., Ravello A. Clinical outcome measures in juvenile idiopathic arthritis. Pediatric Rheumatology, 2016; 14: 23. doi: 10.1186/s12969-016-0085-5.

21. Consolaro A., Varnier G. C., martini A., Ravelli A. Advances in biomarkers for paediatric rheumatologic diseases. Nature review. Rheumatology, 2015; 11: 265-275.

22. David C. M., Elavarasi P. Functional anatomy and biomechanics ot temporomandibular joint and the far-reaching effects of its disorders. Journal of Advanced Clinical \& Research Insights, 2016; 3: 101-106.

23. Diamantberger M. S. Du rheumatisme noueux (polyarthrite déformante) chez les enfants. Academic dissertation. Lecroisnier et Babe Libraires, 1890 (Paris).

24. Fam A. G., Lawry G. V., Kreder H. I. Musculosceletal Examination and Joint Injection Techniques. Mosby, Elsevier, 2006, 7-10.

25. Farman A. G., Scarfe W. C. The basics of maxillofacial cone beam Computed Tomography. Seminars in Orthodontics, 2009; 15(1): 2-13.

26. Farronato G., Carletti V., Maspero C., Farronato D., Giannini L., Bellintani C. Craniofaciao growth in children affected by juvenile idiopathic arthritis involving the temporomandibular joint: funtional therapy management. The Journal of Clinical Pediatric Dentistry, 2009; 33(4): 351358.

27. Ferraz, Júnior A. M. L., Devito K. L., Guimarães J. P., Gerais M. Temporomandibular disorder in patients with juvenile idiopathic arthritis: clinical evaluation and correlation with the findings of cone beam computed tomography. Oral Surgery, Oral Medicine, Oral Pathology, Oral Radiology and Endodontology, 2012; 114: e51-e57.

28. Fjeld M. G., Arvidson L., Smith H. J., et al. Relationship between disease course in the temporomandibular joints and mandibular growth rotation in patients with juvenile idiopathic arthritis followed from childhood to adulthood. http://www.ped-rheum.com/content/8/1/13 (sk. 22.04.2010.)

29. Fjeld M. G., Arvidsson L. Z., Stabrun A. E., Birkeland K., Larheim T. A., Gaard B. Average craniofacial development from 6 to 35 years of age in a mixed group of patients with juvenile idiopathic arthritis. Acta Odontologica Scandinavica, 2009; 67: 153-160.

30. Foeldvari I., Tzaribachev N., Cron R. Q. Results of a multinational survey regarding diagnosis and treatment of the temporomandibular joint involvement in juvenile idiopathic arthritis. Pediatric Rheumatology, 2014. 12: 6. doi 10.1186/1546-0096-12-6.

31. Foster H. E., Jandial S. pGALS - paediatric Gait Arms Legs and Spine: a simple examination of the musculoskeletal system. Pediatric Rheumatology, 2013; 11: 44.

32. El Assar de la Fuente S., Angenete O., Jellestad S., Tzaribachev N., Koos B., Rosendahl K. Juvenile idiopathic arthritis and the temporomandibular joint: A comprehensive review. Journal of Craniomaxillofacial Surgery, 2016 May; 44(5): 597-607. doi: 10.1016/j.jcms.2016.01.014. Epub 2016 Feb 3.

33. Harbage B., Dean A. G. Distribution of epi info software: An evaluation using the Internet. American Journal of Preventive Medicine, 1999; 16(4): 314-317.

34. Hauser R. A., Scroeder S., Cannizzaro E., Muller L., Kellenberger C., Saurenmann R. K. How important is early magnetic resonance imaging of the temporomandibular joint for the treatment of children with juvenile idiopathic arthritis: a retrospective analysis. Pediatric Rheumatology, 2014; $12: 36$.

35. Helm-van Mil A. H. M., Huizinga T. W. J., Schreuder G. M. Th., Breedveld F. C., Vries R. R. P., Toes R. E. M. An independent role of protective HLA class II alleles in Rheumatoid Arthritis severity and susceptibility. Arthritis \& Rheumatism, 2005; 52(9): 2637-2644.

36. Hersh A. O., Prahalad S. Immunogenetics of juvenile idiopathic arthritis: a comprehensive review. Journal of Autoimmunity, 2015; 64: 111-124.

37. Hinks A., Bowes J., Cobb J., Ainsworth H. C., et al. Fine-mapping the MHC locus in juvenile idiopathic arthritis (JIA) reveals genetic heterogeneity corresponding to distinct adult inflammatory arthritic diseases. Annals of Rheumatic Diseases, 2017; 76: 765-772. doi:10.1136/annrheumdis-2016-210025. 
38. Hinks A., Cobb. J., Marion M.C., et al. Dense genotyping of immune loci in juvenile idiopathic arthritis identifies 14 new susceptibility loci. Nature Genetics, 2013; 45: 664 - 669.

39. Holzinger D., Frosch M., Kastrup A., Prince F.H.M., Otten M.H., Van Suijlekom-Smit L.W.A., et al. The Toll-like receptor 4 agonist MRP8/14 protein complex is a sensitive indicator for disease activity and predicts relapses in systemic-onset juvenile idiopathic arthritis. Annals of Rheumatic Diseases, 2012; 71(6): 974-980.

40. Hollenbach J. A., Thompson S. D., Bugawan T. L., Ryan M., Sudman M., Marion M., Langefeld C. D., Thomson G., Erlich H. A., Glass D. N. Juvenile idiopathic arthritis and HLA class I and class II interactions and age-at-onset effects. Arthritis \& Rheumatology, 2010; 62(6): 1781-1791.

41. Hsieh Y.-J., Darvann T. A., Hermann N. V., Larsen P., et al. Facial morphology in children and adolescents with juvenile idiopathic arthritis and moderate to severe temporomandibular joint involvement. American Journal of Orthodonty and Dentofacial Orthopedy, 2016 Feb; 149(2): $182-191$.

42. Huentjens E., Kiss G., Wouters C., Carels C. Condylar asymmetry in children with juvenile idiopathic arthritis assessed by cone-beam computed tomography. The European Journal of Orthodontics, 2008; 30(6): 545-551.

43. Ince D. O., Ince A., Moore T. L. The effect of methotrexate on the temporomandibular joint in polyarticular juvenile rheumatoid arthritis patients. Journal of Clinical Rheumatology, 1999 Dec; 5(6): 320-325.

44. Jank S., Haase S., Strobl H., Michels H., et al. Sonographic investigation of the temporomandibular joint in patients with juvenile idiopathic arthritis: a pilot study. Arthritis \& Rheumatism, 2007; 57(2): 213-218.

45. Kalle von T., Winkler P., Stuber T. Contrast-enhanced MRI of normal temporomandibular joints in children - is there enhancement or not? Rheumatology (Oxford), 2013; 52(2): 363-367.

46. Karlo C. A., Stolzmann P., Habernig S., Müller L., et al. Size, shape and age-related changes of the mandibular condyle during childhood. Europian Radiology, 2010; 20(10): 2512-2517. doi: 10.1007/s00330-010-1828-1. Epub 2010 Jun 18.

47. Kellenberger C. J., Arvidsson L. Z., Larheim T. A. Magnetic resonance imaging of temporomandibular joints in juvenile idiopathic arthritis. Seminars in Orthodontics, 2015; 21: $111-120$.

48. Keller H., Müller L. M., Markic G., Schraner T., Kellenberger C. J., Saurenmann R. K. Is early TMJ involvement in children with juvenile idiopathic arthritis clinically detectable? Clinical examination of the TMJ in comparison with contrast enhanced MRI in patients with juvenile idiopathic arthritis. Pediatric Rheumatology Online Journal, 2015 Dec 9; 13: 56. doi: 10.1186/s12969-015-0056-2.

49. Koos B., Tzaribachev N., Bott S., Ciesielski R., Godt A. Classification of temporomandibular joint erosion, arthritis, and inflammation in patients with juvenile idiopathic arthritis. Journal of Orofacial Orthopedy, 2013 Nov; 74(6): 506-519. doi: 10.1007/s00056-013-0166-8. Epub 2013 Nov 1.

50. Koos B., Twilt M., Kyank U., Fischer-Brandies H., Gassling V., Tzaribachev N. Reliability of clinical symptoms in diagnosing temporomandibular joint arthritis in juvenile idiopathic arthritis. The Journal of Rheumatology, 2014; 41(9): 1871-1877.

51. Kristensen K. D., Stoustrup P., Küseler A., Pedersen T., Twilt M., Herlin T. Clinical predictors of temporomandibular joint arthritis in juvenile idiopathic arthritis: A systematic literature review. Seminars in Arthritis and Rheumatism, 2016 Jun; 45(6): 717-732.

52. Küseler A., Pedersen T. K., Herlin T., Gelineck J. Contrast enhanced magnetic resonance imaging as a method to diagnose early inflammatory changes in the temporomandibular joint in children with juvenile chronic arthritis. Journal of Rheumatology, 1998 Jul; 25(7): 1406-1412.

53. Landis J. R., \& Koch G. G. The measurement of observer agreement for categorical data. Biometrics, 1977; 33: 159-174.

54. Larheim T. A., Doria A. S., Kirkhus E., Parra D. A., Kellenberger C. J., Arvidsson L. Z.. TMJ imaging in JIA patients - an overview. Seminars in Orthodonty, 2015; 21: 102-110.

55. Latvijas Pediatru reimatologu asociācija. Juvenīla idiopātiska artrīta klīniskās vadlīnijas. Nacionālais veselības dienests, rīkojums 21.06.2016. Nr. KV 03-2016. 
56. Ma G. M. Y., Amirabadi A., Inarejos E., Tolend M., Stimec J., Moineddin R., Spiegel L., Dora A. S. MRI thresholds for discrimination between normal and mild temporomandibular joint involvement in juvenile idiopathic arthritis. Pediatric Rheumatology, 2015 Dec 1; 13: 53. doi: 10.1186/s12969-015-0051-7.

57. Melis M., Secci S., Ceneviz C. Use of ultrasonography for the diagnosis of temporomandibular joint disorders: a review. American Journal of Dentistry, 2007; 20: 73-78.

58. Meyers A. B., Laor T. Magnetic resonance imaging of the temporomandibular joint in children with juvenile idiopathic arthritis. Pediatric Radiology, 2013, 43: 1632-1641.

59. Mina R., Melson P., Powell S., et al. Effectiveness of dexamehasone iontophoreis for temporomandibular joint involvement in juvenile idiopathic arthritis. Arthritis Care Research (Hoboken), 2011; 63: 1511-1516.

60. Mizoguchi I., Toriya N., Nakao Y. Growth of the mandible and biological characteristics of the mandibular condylar cartilage. Japanese Dental Science, 2013; 49: 139-150.

61. Moe J. S., Desai N. K., Aiken A. H., Soares B. P., Kang J., Abramowicz S. Magnetic resonance imaging of temporomandibular joints of children. Journal of Oral Maxillofacial Surgery, 2016 Sep; 74(9): 1723-1727.

62. Mohammed Y., Saeed O., Zaghloul N., Samer S., Mahmud S., Abdulah A. Juvenile idiopathic arthritis and the temporomandibular joint. Alexandria Journal of Medicine, 2012; 48: 123-129.

63. Morton D. A., Foreman K., Albertine K. H. Chapter 21. Infratemporal Fossa. In: Morton D. A., Foreman K., Albertine K. H., eds. The Big Picture: Gross Anatomy. New York, NY: Lange, 2011.

http://accessmedicine.mhmedical.com.db.rsu.lv/content.aspx?bookid=381\&Sectionid=40140029.

64. Müller L., Kellenberger C. J., Cannizzaro E., et al. Early diagnosis of temporomandibular joint involvement in juvenile idiopathic arthritis: a pilot study comparing clinical examination and ultrasound to magnetic resonance imaging. Rheumatology, 2009; 48: 680-685.

65. Murray K. J., Moroldo M. B.,Donnelly P., Prahalad S., Passo M. H., Giannini E. H., et al. Agespecific effects of juvenile rheumatoid arthritis-associated HLA alleles. Arthritis and Rheumatology, 1999; 42: 1843-1853.

66. Mussler A., Allozy B, Landau H. et al. Comparsion of magnetic resonance imaging signs and clinical findings in follow-up examinations in children with temporomandibular joint involvement in juvenile idiopathic arthritis. Rofo, $2010 \mathrm{Jan}$; 182(1): 33-44.

67. Parra D. A., Chan M., Krishnamurty G., Spiegel L., Amaral J. G., Temple M. J., John P. R., Connolly B. L. Use and accuracy of US guidance for image-guided injections of the temporomandibular joints in children with arthritis. Pediatric Radiology, 2010 Sep; 40(9): 498504.

68. Paul S. A., Simon S. S., Issac B., Kumar S. Management of severe sleep apnea secondary to juvenile arthritis with temporomandibular joint replacement and mandibular advancement. Journal of Pharmacy And Bioallied Sciences, 2015 Aug; 7(Suppl 2): S68-90.

69. Pedersen T. K., Jensen J. J., Melsen B., et al. Resorbtion of the temporomandibular condylar bone according to subtypes of juvenile chronic arthritis. Journal of Rheumatology, 2001; 28: 21092115.

70. Pedersen T. K., Kuseler A., Gelineck J., Herlin T. A prospective study of magnetic resonance and raiographic imaging in relation to symptoms and clinical findings of the temporomandibular joint in children with juvenile idiopathic arthritis. Journal of Rheumatology, 2008 Aug; 35(8): 16681675.

71. Peltomäki T., Kreiborg S., Pedersen T. K., and Ogaard B. Craniofacial growth and dento-alveolar development in juvenile idiopathic arthritis patients. Seminars in Orthodonty, 2015; 21: 84-93.

72. Perttiniemi P., Peltomaki T., Müller L., Luder H. U. Abnormal mandibular growth and the condylar cartilage. European Journal of Orthodontics, 2009; 31: 1-11.

73. Petty R. E., Laxer R. M., Lindsley C. B., Wedderburn L. R. Textbook of Pediatric Rheumatology. Seventh ed. Philadelphia: Elsevier, 2016, 188, 243.

74. Pratsidou-Gertsi P., Kanakoudi-Tsakalidou F., Spyropoulou M., Germenis A., et al. Nationwide collaborative study of HLA class II associations with distinct types of juvenile chronic arthritis (JCA) in Greece. European Journal of Immunogenetics, 1999; 26: 299-310.

75. QIAamp DNA Mini and Blood Mini Handbook - EN. Avalaible at: http://www.qiagen.com/ resources/resourced (sk. 02.03.2014.).

76. Ravelli A., Martini A. Juvenile idiopathic arthritis. Lancet, 2007; 369: 767-778. 
77. Resnick C. M., Dang Rushil, Henderson L. A., Zander D. A., Daniels K. M., Nigrovic P. A., Kaban L. B. Frequency and morbidity of temporomandibular joint involvement in adult patients with a history of juvenile idiopathic arthritis. Journal of Oral Maxillofacial Surgery, 2016; 75 (6): 1191-1200.

78. Ringold S., Cron R. Q. The temporomandibular joint in juvenile idiopathic arthritis: frequently used and frequently arthritic. http://www.ped-rheum.com/content/7/1/11 (sk. 29.05.2009.).

79. Ringold S., Torgerson T. R., Egbert M. A., Wallace C. A., et al. Intraarticular corticosteroid injections of the temporomandibular joint in juvenile idiopathic arthritis. Journal of Rheumatology, 2008; 35 (6): 1157-1164.

80. Rönning O., Barnes S. A. R., Pearson M. H., Pledger D. M. Juvenile chronic arthritis: a cephalometric analysis of the facial skeleton. The European Journal of Orthodontics, 1994; 16: 53-62.

81. Ropper A. H., Samuels M. A., Klein J. P. Chapter 10. Headache and other craniofacial pains. In: Ropper A. H., Samuels M. A., Klein J. P., eds. Adams \& Victor's Principles of Neurology.10th ed. New York, NY: McGraw-Hill, 2014. http://accessmedicine.mhmedical.com.db. rsu.lv/content.aspx?bookid=690\&Sectionid=45424418 (sk. 05.05.2016.).

82. Rumba I., Ruperto N., Bikis E., Remberga S., Saulite I., et al. The Latvian version of the Childhood Health Assesment Quetionnaire (CHAQ) and the Child Health Questionnaire (CHQ). Clinical and Experimantal Rheumatology, 2001 Jul-Aug; 19(4 Suppl 23): S101-105.

83. Rumba I., Denisova A., Sochnev A., Nillson B., Sanjeevi C. B. HLA II class genes in Latvian patients with juvenile rheumatoid arthritis. Tissue Antigens, 1997: 49: 56-60.

84. Runstadler J. A., Säilä H., Savolaine A., Leirisalo-Repo M., et al. Analysis of MHC region genetics in Finnish patients with juvenile idiopathic arthritis: evidence for different locus-specific effects in polyarticular vs pauciarticular subsets and a shared DRB1 epitope. Genes and Immunity, 2003; 4: 326-335.

85. Scolozzi P., Bosson G., Jaques B. Severe isolated temporomandibular joint involvement in juvenile idiopathic arthritis. Journal of Oral and Maxillofacial Surgery, 2005; 63(9): 136-1371.

86. Sheybani E. F. , Khanna G., White A. J., Demertzis J. L. Imaging of juvenile idiopathic arthritis: a multimodality approach. RadioGraphics, Sep 2013; 33: 1253-1273. doi:10.1148/rg.335125178.

87. Silva-Ramirez B., Cerda-Flores R. M., Rubio-Pérez N., Vargas-Alarcón G., et al. Association of HLA DRB1 alleles with juvenile idiopathic arthritis in Mexicans. Clinical and Experimental Rheumatology, 2010; 28(1): 124-127.

88. Stanevicha V., Eglite J., Sochnevs A., et al. HLA Class II associations with rheumatic heart disease among clinically homogeneous patients in children in Latvia. Arthritis Research \& Therapy, 2003; 5(6): R340-R346.

89. Stastny P., Fink C. W. Different HLA-D associations in adult and juvenile rheumatoid arthritis. Journal of Clinical Investigations, 1979; 63: 124-130.

90. Steenks M. H., Giancane G., de Leeuw R. R., Bronkhorst E. M., et al. Temporomandibular joint involvement in juvenile idiopathic arthritis: reliability and validity of a screening protocol for the rheumatologist. Pediatric Rheumatology Online Journal, 2015 May 7; 13: 15. doi: 10.1186/s12969-015-0011-2.

91. Stoll M. L., Good J., Sharpe T., et al. Intra-articular corticosteroid injections to the temporomandibular joints are safe and appear to be effective therapy in children with juvenile idiopathic arthritis. Journal of Oral and Maxillofacial Surgery, 2012; 70(8): 1802-1807.

92. Stoll M. L., Morlandt A. B., Teerawattanapong S., Young D., et al. Safety and efficacy of intraarticular infiximab therapy for treatment-resistant temporomandibular joint arthritis in children: a retrospective study. Rheumatology (Oxford), 2013; 52: 554-559.

93. Stoll M. L., Sharpe T., Beukelman T., et al. Risk factors for temporomandibular joint arthritis in children with juvenile idiopathic arthritis. Journal of Rheumatology, 2012; 39(9): 1880-1887.

94. Stoustrup P., Koos B. Clinical craniofacial examination of patients with juvenile idiopathic arthritis. Seminars in Orthodonthy, 2015; 21: 94-101.

95. Stoustrup P., Kristensen K. D., Kuseler A., Gelineck J., et al. Reduced mandibular growth in experimental arthritis in the temporomandibular joint treated with intra-articular corticosteroid. European Journal of Orthodonthy, 2008; 30: 111-119.

96. Stoustrup P., Kristensen K. D., Kuseler A., Pedersen T. K., Gelineck J., Herlin T. Intra-articular vs. systemic administration of etanercept in antigen-induced arthritis in the temporomandibular joint. Part II: Mandibular growth. Pediatric Rheumatology Online Journal, 2009; 7: 6. 
97. Stoustrup P., Kristensen K. D., Verna C., Kuseler A., et al. Intra-articular steroid injection for temporomandibular joint arthritis in juvenile idiopathic arthritis: A systematic review on efficacy and safety. Seminars in Arthritis and Rheumatology, 2013 Aug; 43(1): 63-70.

98. Stoustrup P., Twilt M., Spiegel L., Kristensen K. D., Koos B., Pedersen T. K., Kuseler A., Cron R. C., Abramowicz S., Verna C., Peltomaki T., Alstergen P., Petty R., Ringold S., Norholt S. E., Saurenmann R. K., Herlin T. Clinical orofacial examination in juvenile idiopathic arthritis: international consesnus-based recomedations for monitoring patients in clinical practice and reasearch studies. The Journal of Rheumatology, 2015. doi:10.3899/jrheum.160796.

99. Twilt M., Mobers S. M., Arends L. R., ten Cate R., van Suijlekom-Smit L. Temporomandibular involvement in juvenile idiopathic arthritis. The Journal of Rheumatology, 2004; 31(7): 14181422.

100. Twilt M., Schulten A. J. M., Nicolaas P., Dülger A., van Suijlekom-Smit. Facioskeletal changes in children with juvenile idiopathic arthritis. Annals of Rheumatic Diseases, 2006; 65: 823-825.

101. Twilt M., Schulten A. J. M., Verschure F., Wisse L., et al. Long-term followup of temporomandibular joint involvement in juvenile idiopathic arthritis. Arthritis \& Rheumatism, 2008; 59(4): 546-552.

102. Thomson W., Barrett J. H., Donn R., Pepper L., Kennedy L. J., Ollier W. E. R., Silman A. J. S. British Paediatric Rheumatology Study Group, Woo P., and Southwood T. Juvenile idiopathic arthritis classified by the ILAR criteria: HLA associations in UK patients. Rheumatology, 2002; 41(10): 1183-1189.

103. Thomson W., Donn R. Juvenile idiopathic arhtirits genetics: What's new? What's next? Arthritis Research, 2002; 4: 302-306

104. User manual HLA-DRB1, DQ alleles genotyping Kit. www.dnatechnology.ru/files/images/instructions.308.pdf

105. Wallace C. A., Giannini E. H., Huang B., Itert L., Ruperto N.; Childhood Arthritis and Rheumatology Research Alliance (CARRA), the Pediatric Rheumatology Collaborative Study Group (PRCSG), and the Paediatric Rheumatology International Trials Organisation (PRINTO). American College of Rheumatology provisional criteria for defining clinical inactive disease in select categories of juvenile idiopathic arthritis. Arthritis Care Research (Hoboken), 2011; 63: 929-936.

106. Weiss P. F., Arabshahi B., Johnson A., et al. High prevalence of temporomandibular joint arthritis at disease onset in children with juvenile idiopathic arthritis, as detected by magnetic resonance imaging but not ultrasound. Arthritis and Rheumatism, 2008 Apr; 58(4): 1189-1196.

107. Wong L., Jiang K., Chen Y., Jarvis J.N. Genetic insights into juvenile idiopathic arthritis derived from deep whole genome sequencing. Scientific reports, 2017; 7:2657

108. Vaid Y. N., Dunnavant F. D., Royal S. A., Beukelman T., Stoll M. L., Cron R. Q. Imaging of the temporomandibular joint in juvenile idiopathic arthritis. Arthritis Care and Research (Hoboken), 2014 Jan; 66(1): 47-54. doi: 10.1002/acr.22177.

109. Veldhuis E. C., Veldhuis A. H., Koudstaal M. J. Treatment management of children with juvenile idiopathic arthritis with temporomandibular joint involvement: a systematic review. Oral Surgery and Oral Medicine and Oral Pathology and Oral Radiology, 2014; 117: 581-589.

110. Vicario J. L., Martinez-Laso J., Gomez-Reino J. J., Gomez-Reino F. J., Regueiro J. R., Corell A., et al. Both HLA class II and class III DNA polymorphisms are linked to juvenile rheumatoid arthritis susceptibility. Clinical Immunology and Immunopathology, 1990; 56: e22-e28. 


\section{Publikācijas un prezentācijas par promocijas darba tēmu}

\section{Zinātniskie raksti (4)}

1. Staṇēviča V., Dāvidsone Z., Šantere R., Dzelzīte S., Krišjāne Z., Urtāne I., Strazdiṇa D. Temporomandibulāro locītavu artrīta diagnostika un lokālā terapija juvenila idiopātiska artrīta slimniekiem. RSU Zinātniskie raksti, 2013, 7-9.

2. Dāvidsone Z., Eglīte J., Dzelzīte S., Lazareva A., Šantere R., Bērziņa D., Stan̄ēviča V. HLA II klases alēles juvenila idiopātiska artrīta slimniekiem ar temporomandibulāro locītavu artrītu. RSU zinātniskie raksti, 2014, 229.-234. 1pp.

3. Dāvidsone Z., Eglīte J., Lazareva A., Dzelzīte S., Šantere R., Bērziņa D., Staņēviča V.. HLA II class alleles in juvenile idiopathic arthritis patients with and without temporomandibular joint arthritis. Pediatr Rheumatol Online J. 2016; 14: 24.

4. Al-Shwaikh H., Urtane I., Pirttiniemi P., Pesonen P., Krisjane Z., Jankovska I., Davidsone Z., Stanevica V. Radiologic features of temporomandibular joint osseous structures in children with juvenile idiopathic arthritis. Cone beam computed tomography study. Stomatologija. 2016, 18 (2): 51-60.

\section{Tēzes un prezentācijas starptautiskās konferencēs (6)}

1. Davidsone Z., Eglite J., Dzelzite S., Lazareva A., Santere R., Berzina D., Stanevicha V. HLA II class alleles in juvenile idiopathic arthritis patients with temporomandibular joint involvement. PreS (bērnu reimatologu) kongresā Belgradā 2014. gada septembrī. Pediatric Rheumatology Online Journal, 2014; 12(Suppl 1): P24. (Tēzes un mutisks stenda referāts.)

2. Davidsone Z., Staṇēviča V., Eglīte J, Dzelzīte S., Lazareva A., Bērziṇa D., Šantere R. Risk of temporomandibular joint involvement in juvenile idiopathic arthritis patients with polyarticular course. The Gerry Schwartz and Heather Reisman 4 th International Conference on Pediatric Chronic Diseases, Disability and Human Development. Jeruzaleme, 2015. gada 20.-23. janvārī. (Tēzes un stenda referāts.)

3. Davidsone Z. Early recognition of TMJ arthritis in JIA patients - importance of MRI. Baltijas Reimatologu konference, Jūrmala, 2013. (Mutisks ziņojums.)

4. Davidsone Z Z. Temporomandibular joint involvement in juvenile idiopathic arthritis patients, Baltijas Pediatru kongress, Rīga, 2015. (Mutisks ziṇojums.)

5. Davidsone Z., Šantere R., Bērzina D., Stan̄ēviča V. Temporomandibular joint magnetic resonance imaging findings correlated with subjective and objective symptoms in patients with juvenile idiopathic arthritis. Tēzes PreS konferencē Dženovā 2016. gada 30. septembrī. (Stenda referāts.) 
6. Davidsone Z., Eglite J., Kolesovs A., Santere R., Stanevica V. HLA II class alleles in juvenile idiopathic arthritis patients with and without chronic arthritis signs in temporomandibular joints evaluated with contrast enhanced MRI. Tēzes PReS konferencē Atēnās 2017. gada septembrī. (Stenda referāts.)

\section{Tēzes un prezentācijas vietēja mēroga konferencēs Latvijā (5)}

1. Al-Shvaikh H., Krisjane Z., Jankovska I., Davidsone Z., Urtane I., Stanevica V. Disorders of Osseous Structure of TMJ in Children with Juvenile Idiopathic Arthritis- CBCT Study. RSU zinātniskā konference 2013: Tēzes. Rīga: RSU, 2013, 293. lpp. (Mutisks referāts.)

2. Staṇēviča V., Dāvidsone Z., Šantere R., Krišjāne Z., Urtāne I. Temporomandibulāro locītavu artrīta diagnostika un terapija juvenila idiopātiska artrīta pacientiem. RSU zinātniskā konference 2013: Tēzes. Rīga: RSU, 2013, 215. lpp. (Mutisks referāts.)

3. Dāvidsone Z., Eglīte J., Staṇēviča V., Dzelzīte S., Šantere R., Lazareva A., Bērziṇa D. HLA II klases alēles pacientiem ar juvenilu idiopātisku artrītu un temporomandibulāro locītavu iekaisumu. RSU zinātniskā konference 2014: Tēzes. Rīga: RSU, 2014, 243. 1pp. (Stenda referāts.)

4. Dāvidsone Z., Dzelzịte S., Lazareva A., Šantere R., Bērziṇa D., Stāṇēviča V.. Temporomandibulāro locītavu magnētiskās rezonanses izmeklējuma atrade un klīniskie simptomi pacientiem ar juvenilu idiopātisku artrītu. RSU zinātniskā konference 2015: Tēzes. Rīga: RSU, 2015, 234. lpp. (Stenda referāts.)

5. Dāvidsone Z., Lazareva A., Šantere R., Bērziņa D., Staṇēviča V. Temporomandibulāro locītavu artrīta attīstību ietekmējošie faktori pacientiem ar juvenilu idiopātisku artrītu. RSU zinātniskā konference 2016: Tēzes. Rīga: RSU, 2016, 148. lpp. (Stenda referāts.) 


\section{PATEICĪBAS}

Vēlos pateikties savai promocijas darba vadītājai profesorei Valdai Staṇēvičai par pamudinājumu studēt doktorantūrā, pacietību un atbalstu promocijas darba tapšanas procesā.

Izsaku pateicību RSU Klīniskās imunoloǵijas un imunoǵenētikas starpkatedru laboratorijas vadošajai pētniecei Dr. med. Jel̦enai Eglītei par atbalstu visa pētījumā laikā, gan veicot HLA alēlu genotipēšanu, gan konsultējot par pētījuma teorētiskajiem jautājumiem.

Paldies RSU Stomatologiijas institūta profesorei Ilgai Urtāne par iedvesmu promocijas darba tēmai un bērnu reimatologu un ortodontu sadarbības veicināšanu.

Pateicos bērnu reimatologijas virsārstei dakterei Rutai Šanterei - manai skolotājai bērnu reimatologa praktiskajā darbā, kā arī citiem bērnu reimatologiem par atbalstu promocijas darba tapšanā, palīdzot atlasīt pētījuma pacientus. Izsaku pateicību arī BKUS reimatoloǵijas profila māsām, kas palīdzēja ar analīžu noņemšanu pacientiem. Paldies pacientiem un viņu vecākiem par uzticību un piekrišanu piedalīties pētījumā. Paldies arī BKUS, jo, pateicoties iespējai šeit strādāt, ir bijusi arī iespēja veikt promocijas darbu.

Paldies BKUS radiologiem dakterei Sarmītei Dzelzītei un dakterei Jolantai Rozentālei par atbalstu radiologisko izmeklējumu veikšanā un aprakstīšanā.

Sirsnīgs paldies RSU Doktorantūras nodaḷas pētniecības procesa organizatorei Irēnai Rogovskai par palīdzību pētījuma strukturēšanā, statistisko metožu izvēlē un datu apstrādē.

Saku paldies RSU Pediatrijas katedras vadītājai profesorei Dacei Gardovskai par iespēju strādāt izglītojošo darbu ar studentiem un atrasties vidē, kas veicina pētniecisko darbību.

Paldies RSU par doto iespēju studēt doktorantūrā, kā arī par iespēju saņemt studiju grantus promocijas darba tehniskai nodrošināšanai.

Paldies farmācijas firmas Roche akadēmijai par atbalstu radiologisisko izmeklējumu veikšanai.

Paldies maniem draugiem Dr. med. Elīnai Ligerei un Madarai Miķelsonei par morālu un tehnisku atbalstu darba tapšanas laikā.

Vislielākais paldies manai māmiņai Annai Šmitei, bez kuras palīdzības ikdienas rūpēs šis darbs nebūtu iespējams. Paldies arī vīram Dināram un bērniem Kārlim un Dārtai par pacietību darba tapšanas laikā. 


\section{PIELIKUMI}




\section{Centrālā medicīnas ētikas komiteja}

$\frac{\text { Brīvìbas iela 72, Rīga, LV-1011 •Tālr. 67876182 •Fakss 67876071 • E-pasts: vm@vm.gov.lv }}{\text { Rīgā }}$

Rīgas Stradiņa universitātes

Pediatrijas katedrai

Atzinums Nr.01-29.1/1 par pieteikuma

projektu "Deniņu-apakšžokļa locitavas

saistības ar juvelīno idiopātisko artrītu

genētiskās ietekmes izpēte"

Centrālā medicīnas ētikas komiteja 2013.gada 6.februārī izskatīja Rīgas Stradina universitātes Pediatrijas katedras iesniegto pieteikuma projektu „Deniņu - apakšžokḷa locītavas saistības ar juvenīlo idiopātisko artrītu genētiskās ietekmes izpēte".

- Pamatojoties uz Centrālās medicīnas ētikas komitejas 2013. gada 6.februāra sēdes protokola Nr.1 punktu 1, tiek izsniegts atzinums, ka Rīgas Stradina universitātes Pediatrijas katedras pieteikuma projekts „Deniņu - apakšžokḷa locītavas saistības ar juvenīlo idiopātisko artrītu genētiskās ietekmes izpēte" nav pretrunā ar bioētikas normām.

Centrālās medicīnas ētikas

komitejas priekšsēdētājs

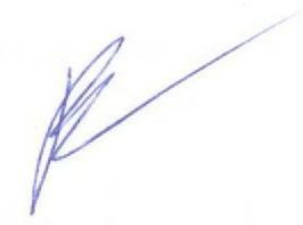

R.Muciņš 
HLA II klases alēl̨u genotipēšans rezultāti MRI pozitīvajā grupā pret veselo indivīdu kontroles grupu

2. pielikums

\begin{tabular}{|c|c|c|c|c|c|c|c|c|c|c|}
\hline & $\begin{array}{c}\text { MRI } \\
\text { pozitīvie } \\
\text { (alēḷu skaits } \\
=144 \text { ) }\end{array}$ & 144 & $\begin{array}{l}\text { kontrole } \\
\text { (alēlu skaits } \\
\quad=200 \text { ) }\end{array}$ & 200 & hī kvadrātā & $\mathrm{p}$ & OR & $\begin{array}{c}\text { CI 95\% } \\
\text { OR apakš. }\end{array}$ & $\begin{array}{c}\text { CI 95\% OR } \\
\text { augšs. }\end{array}$ & $\mathrm{p}$ \\
\hline & biežums & $\begin{array}{c}\text { relatīvais } \\
\text { biežums }\end{array}$ & biežums & $\begin{array}{c}\text { relatīvais } \\
\text { biežums }\end{array}$ & & & & & & \\
\hline \multicolumn{11}{|l|}{ DRB1 } \\
\hline DRB1_01 & 23 & 0,16 & 26 & 0,13 & 0,61 & 0,436 & 1,27 & 0,69 & 2,33 & 0,437 \\
\hline DRB1_04 & 13 & 0,09 & 23 & 0,12 & 0,55 & 0,460 & 0,76 & 0,37 & 1,56 & 0,461 \\
\hline DRB1_07 & 20 & 0,14 & 4 & 0,02 & 18,23 & 0,001 & 7,90 & 2,64 & 23,67 & 0,001 \\
\hline DRB1_08 & 0 & 0,00 & 12 & 0,06 & 8,95 & 0,003 & 0,05 & 0,01 & 0,89 & 0,041 \\
\hline DRB1_09 & 0 & 0,00 & 2 & 0,01 & 1,44 & 0,229 & 0,27 & 0,01 & 5,77 & 0,406 \\
\hline DRB1_10 & 0 & 0,00 & 5 & 0,03 & 3,65 & 0,056 & 0,12 & 0,01 & 2,24 & 0,157 \\
\hline DRB1_11 & 20 & 0,14 & 14 & 0,07 & 4,46 & 0,035 & 2,14 & 1,04 & 4,40 & 0,038 \\
\hline DRB1_12 & 5 & 0,03 & 18 & 0,09 & 4,10 & 0,043 & 0,36 & 0,13 & 1,01 & 0,051 \\
\hline DRB1_13 & 21 & 0,15 & 14 & 0,07 & 5,27 & 0,022 & 2,27 & 1,11 & 4,63 & 0,024 \\
\hline DRB1_14 & 7 & 0,05 & 16 & 0,08 & 1,32 & 0,250 & 0,59 & 0,24 & 1,47 & 0,255 \\
\hline DRB1_15 & 27 & 0,19 & 16 & 0,08 & 8,85 & 0,003 & 2,65 & 1,37 & 5,14 & 0,004 \\
\hline DRB1_16 & 4 & 0,03 & 28 & 0,14 & 12,50 & 0,001 & 0,18 & 0,06 & 0,51 & 0,001 \\
\hline DRB1_17 & 4 & 0,03 & 22 & 0,11 & 8,10 & 0,004 & 0,23 & 0,08 & 0,69 & 0,009 \\
\hline \multicolumn{11}{|l|}{ DQA1 } \\
\hline DQA1_0101 & 21 & 0,15 & 29 & 0,15 & 0,01 & 0,983 & 1,01 & 0,55 & 1,85 & 0,983 \\
\hline DQA1_0102 & 32 & 0,22 & 43 & 0,22 & 0,03 & 0,873 & 1,04 & 0,62 & 1,75 & 0,873 \\
\hline DQA1_0103 & 12 & 0,08 & 16 & 0,08 & 0,01 & 0,910 & 1,05 & 0,48 & 2,28 & 0,911 \\
\hline
\end{tabular}


2. pielikums (turpinājums)

\begin{tabular}{|c|c|c|c|c|c|c|c|c|c|c|}
\hline & $\begin{array}{c}\text { MRI } \\
\text { pozitivie } \\
\text { (alelelu skaits } \\
=144 \text { ) }\end{array}$ & 144 & $\begin{array}{l}\text { kontrole } \\
\text { (alēlu skaits } \\
=200 \text { ) }\end{array}$ & 200 & \multirow[t]{2}{*}{ hī kvadrātā } & \multirow[t]{2}{*}{$\mathrm{p}$} & \multirow[t]{2}{*}{ OR } & \multirow{2}{*}{$\begin{array}{c}\text { CI 95\% } \\
\text { OR } \\
\text { apakš. }\end{array}$} & \multirow[t]{2}{*}{$\begin{array}{c}\text { CI 95\% OR } \\
\text { augš. }\end{array}$} & \multirow[t]{2}{*}{$\mathrm{p}$} \\
\hline & biežums & $\begin{array}{c}\text { relatīvais } \\
\text { biežums }\end{array}$ & biežums & $\begin{array}{c}\text { relatīvais } \\
\text { biežums }\end{array}$ & & & & & & \\
\hline DQA1_0201 & 21 & 0,15 & 24 & 0,12 & 0,49 & 0,483 & 1,25 & 0,67 & 2,35 & 0,484 \\
\hline DQA1_0301 & 26 & 0,18 & 27 & 0,14 & 1,33 & 0,248 & 1,41 & 0,79 & 2,54 & 0,250 \\
\hline DQA1_0401 & 4 & 0,03 & 7 & 0,04 & 0,14 & 0,707 & 0,79 & 0,23 & 2,74 & 0,708 \\
\hline DQA1_0501 & 28 & 0,19 & 48 & 0,24 & 1,01 & 0,315 & 0,76 & 0,45 & 1,29 & 0,316 \\
\hline DQA1_0601 & 0 & 0,00 & 6 & 0,03 & 4,40 & 0,042 & 0,10 & 0,01 & 1,86 & 0,123 \\
\hline \multicolumn{11}{|l|}{ DQB1 } \\
\hline DQB1_0201_2 & 25 & 0,17 & 32 & 0,16 & 0,11 & 0,738 & 1,10 & 0,62 & 1,96 & 0,738 \\
\hline DQB1_0301 & 32 & 0,22 & 39 & 0,20 & 0,38 & 0,538 & 1,18 & 0,70 & 2,00 & 0,538 \\
\hline DQB1_0302 & 12 & 0,08 & 13 & 0,07 & 0,42 & 0,518 & 1,31 & 0,58 & 2,96 & 0,519 \\
\hline DQB1_0303 & 16 & 0,11 & 13 & 0,07 & 2,31 & 0,129 & 1,80 & 0,84 & 3,87 & 0,133 \\
\hline DQB1_0304 & 0 & 0,00 & 2 & 0,01 & 1,45 & 0,229 & 0,27 & 0,01 & 5,77 & 0,405 \\
\hline DQB1_0305 & 1 & 0,01 & 0 & 0,00 & 1,39 & 0,238 & 4,19 & 0,17 & 103,64 & 0,381 \\
\hline DQB1_0401_2 & 3 & 0,02 & 7 & 0,04 & 0,60 & 0,440 & 0,59 & 0,15 & 2,31 & 0,445 \\
\hline DQB1_0501 & 27 & 0,19 & 22 & 0,11 & 4,12 & 0,042 & 1,87 & 1,02 & 3,43 & 0,045 \\
\hline DQB1_0502_4 & 4 & 0,03 & 12 & 0,06 & 1,96 & 0,162 & 0,45 & 0,14 & 1,42 & 0,172 \\
\hline DQB1_0601 & 1 & 0,01 & 11 & 0,06 & 5,74 & 0,017 & 0,12 & 0,02 & 0,94 & 0,044 \\
\hline DQB1_0602_8 & 23 & 0,16 & 49 & 0,25 & 3,68 & 0,055 & 0,59 & 0,34 & 1,02 & 0,057 \\
\hline
\end{tabular}

$\mathrm{P}<0,05$. P<0,05. Abs. - absolūtais biežums. Rel. - relatīvais biežums. $\chi^{2}$ - hī kvadrāta kritērijs. OR - izredžu attiecība. CI - ticamības intervāls. 
3. pielikums

HLA II klases alēlu genotipēšanas rezultāti MRI negatīvajā grupā pret veselo indivīdu kontroles grupu

\begin{tabular}{|c|c|c|c|c|c|c|c|c|c|c|}
\hline & $\begin{array}{c}\text { MRI } \\
\text { negatīvie } \\
\text { (alēḷu skaits } \\
=38 \text { ) }\end{array}$ & 38 & $\begin{array}{l}\text { kontrole } \\
\text { (alēḷu skaits } \\
\quad=200 \text { ) }\end{array}$ & 200 & \multirow[t]{2}{*}{ hī kvadrātā } & \multirow[t]{2}{*}{$\mathrm{p}$} & \multirow[t]{2}{*}{ OR } & \multirow[t]{2}{*}{$\begin{array}{c}\text { CI 95\% } \\
\text { OR } \\
\text { apakš. }\end{array}$} & \multirow[t]{2}{*}{$\begin{array}{c}\text { CI 95\% OR } \\
\text { augšs. }\end{array}$} & \multirow[t]{2}{*}{$\mathrm{p}$} \\
\hline & biežums & $\begin{array}{c}\text { relatīvais } \\
\text { biežums }\end{array}$ & biežums & $\begin{array}{c}\text { relatīvais } \\
\text { biežums }\end{array}$ & & & & & & \\
\hline \multicolumn{11}{|l|}{ DRB1 } \\
\hline DRB1_01 & 7 & 0,18 & 26 & 0,13 & 0,79 & 0,375 & 1,51 & 0,60 & 3,78 & 0,378 \\
\hline DRB1_04 & 1 & 0,03 & 23 & 0,12 & 2,77 & 0,140 & 0,21 & 0,03 & 1,59 & 0,130 \\
\hline DRB1_07 & 3 & 0,08 & 4 & 0,02 & 3,89 & 0,083 & 4,20 & 0,90 & 19,58 & 0,069 \\
\hline DRB1_08 & 0 & 0,00 & 12 & 0,06 & 2,40 & 0,223 & 0,20 & 0,01 & 3,38 & 0,262 \\
\hline DRB1_09 & 0 & 0,00 & 2 & 0,01 & 0,38 & 0,999 & 1,03 & 0,05 & 21,90 & 0,984 \\
\hline DRB1_10 & 0 & 0,00 & 5 & 0,03 & 0,97 & 0,999 & 0,46 & 0,03 & 8,52 & 0,603 \\
\hline DRB1_11 & 7 & 0,18 & 14 & 0,07 & 5,18 & 0,023 & 3,00 & 1,12 & 8,02 & 0,029 \\
\hline DRB1_12 & 8 & 0,21 & 18 & 0,09 & 4,77 & 0,029 & 2,70 & 1,08 & 6,75 & 0,034 \\
\hline DRB1_13 & 4 & 0,11 & 14 & 0,07 & 0,57 & 0,451 & 1,56 & 0,49 & 5,04 & 0,454 \\
\hline DRB1_14 & 0 & 0,00 & 16 & 0,08 & 3,26 & 0,082 & 0,15 & 0,01 & 2,47 & 0,018 \\
\hline DRB1_15 & 6 & 0,16 & 16 & 0,08 & 2,31 & 0,129 & 2,16 & 0,79 & 5,92 & 0,136 \\
\hline DRB1_16 & 2 & 0,05 & 28 & 0,14 & 2,21 & 0,137 & 0,34 & 0,08 & 1,50 & 0,154 \\
\hline DRB1_17 & 0 & 0,00 & 22 & 0,11 & 4,61 & 0,030 & 0,10 & 0,01 & 1,74 & 0,114 \\
\hline \multicolumn{11}{|l|}{ DQA1 } \\
\hline DQA1_0101 & 5 & 0,13 & 29 & 0,15 & 0,05 & 0,828 & 0,89 & 0,32 & 2,48 & 0,828 \\
\hline DQA1_0102 & 7 & 0,18 & 43 & 0,22 & 0,18 & 0,669 & 0,82 & 0,34 & 2,00 & 0,670 \\
\hline DQA1_0103 & 4 & 0,11 & 16 & 0,08 & 0,26 & 0,607 & 1,35 & 0,43 & 4,30 & 0,608 \\
\hline DQA1_0201 & 2 & 0,05 & 24 & 0,12 & 1,49 & 0,222 & 0,41 & 0,09 & 1,80 & 0,236 \\
\hline DQA1_0301 & 3 & 0,08 & 27 & 0,14 & 0,91 & 0,340 & 0,55 & 0,16 & 1,91 & 0,346 \\
\hline DQA1_0401 & 2 & 0,05 & 7 & 0,04 & 0,27 & 0,601 & 1,53 & 0,31 & 7,67 & 0,604 \\
\hline
\end{tabular}


3. pielikums (turpinājums)

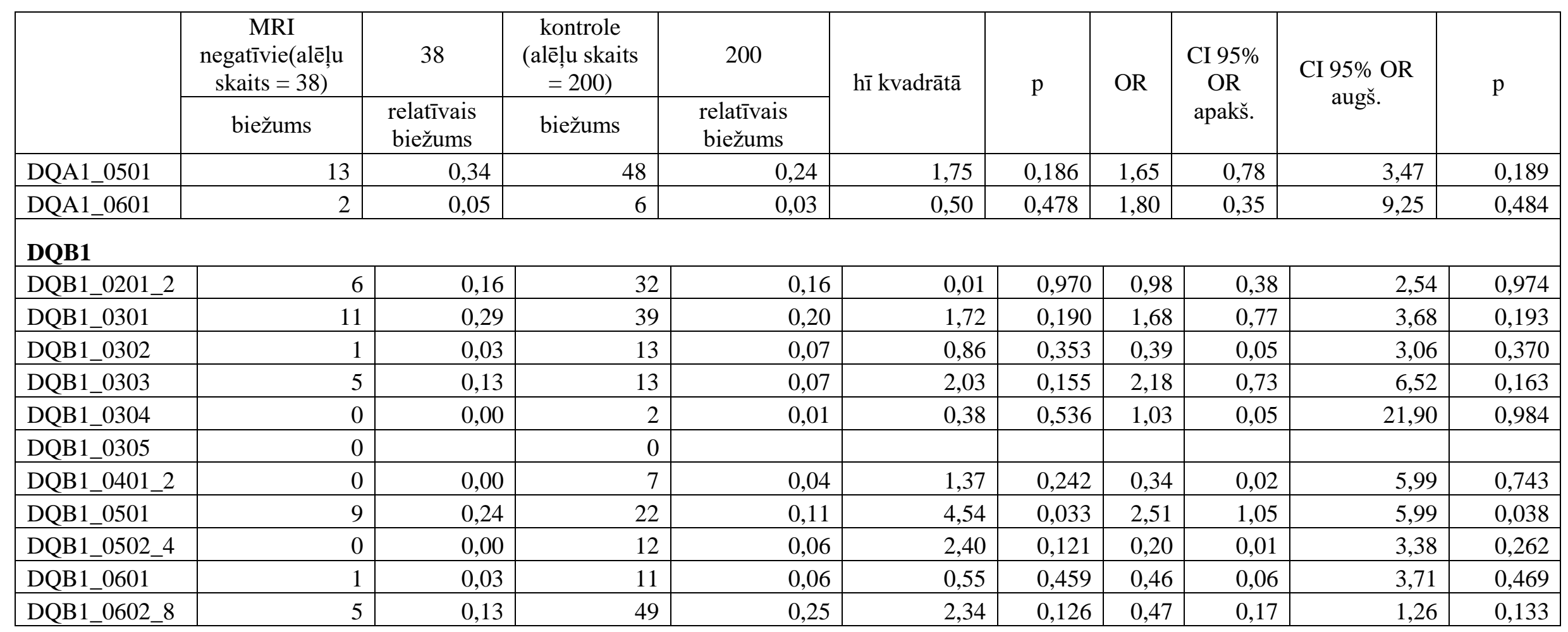

$\mathrm{P}<0,05$. $\mathrm{P}<0,05$. Abs. - absolūtais biežums. Rel. - relatīvais biežums. $\chi^{2}-$ hī kvadrāta kritēijijs. OR - izredžu attiecība. CI - ticamības intervāls. 
4. pielikums

HLA II klases alēlu genotipēšanas rezultāti salīdzinoši MRI pozitīvajā un MRI negatīvajās grupās

\begin{tabular}{|c|c|c|c|c|c|c|c|c|c|c|}
\hline & $\begin{array}{c}\text { MRI } \\
\text { pozitīivie } \\
\text { (alēl,u skaits } \\
=144)\end{array}$ & 144 & $\begin{array}{c}\text { MRI } \\
\text { negatīvie } \\
\text { (alēḷu skaits } \\
=38 \text { ) }\end{array}$ & 38 & \multirow[t]{2}{*}{ hī kvadrātā } & \multirow[t]{2}{*}{$\mathrm{p}$} & \multirow[t]{2}{*}{ OR } & \multirow[t]{2}{*}{$\begin{array}{c}\text { CI 95\% } \\
\text { OR apakš. }\end{array}$} & \multirow[t]{2}{*}{$\begin{array}{c}\text { CI } 95 \% \text { OR } \\
\text { augšs. }\end{array}$} & \multirow[t]{2}{*}{$\mathrm{p}$} \\
\hline & biežums & $\begin{array}{c}\text { relatīvais } \\
\text { biežums }\end{array}$ & biežums & $\begin{array}{c}\text { relatīvais } \\
\text { biežums }\end{array}$ & & & & & & \\
\hline \multicolumn{11}{|l|}{ DRB1 } \\
\hline DRB1_01 & 23 & 0,16 & 7 & 0,18 & 0,13 & 0,717 & 0,84 & 0,33 & 2,14 & 0,761 \\
\hline DRB1_04 & 13 & 0,09 & 1 & 0,03 & 1,73 & 0,188 & 3,67 & 0,47 & 28,99 & 0,217 \\
\hline DRB1_07 & 20 & 0,14 & 3 & 0,08 & 0,98 & 0,323 & 1,88 & 0,53 & 6,70 & 0,329 \\
\hline \multicolumn{11}{|l|}{ DRB1_08 } \\
\hline \multicolumn{11}{|l|}{ DRB1_09 } \\
\hline \multicolumn{11}{|l|}{ DRB1_10 } \\
\hline DRB1_11 & 20 & 0,14 & 7 & 0,18 & 0,49 & 0,484 & 0,71 & 0,28 & 1,84 & 0,486 \\
\hline DRB1_12 & 5 & 0,03 & 8 & 0,21 & 14,01 & 0,000 & 0,14 & 0,04 & 0,44 & 0,001 \\
\hline DRB1_13 & 21 & 0,15 & 4 & 0,11 & 0,42 & 0,518 & 1,45 & 0,47 & 4,51 & 0,520 \\
\hline DRB1_14 & 7 & 0,05 & 0 & 0,00 & 1,92 & 0,348 & 4,20 & 0,23 & 75,19 & 0,330 \\
\hline DRB1_15 & 27 & 0,19 & 6 & 0,16 & 0,18 & 0,674 & 1,23 & 0,47 & 3,24 & 0,674 \\
\hline DRB1_16 & 4 & 0,03 & 2 & 0,05 & 0,58 & 0,445 & 0,51 & 0,09 & 2,92 & 0,453 \\
\hline DRB1_17 & 4 & 0,03 & 0 & 0,00 & 1,08 & 0,581 & 2,47 & 0,13 & 46,81 & 0,548 \\
\hline \multicolumn{11}{|l|}{ DQA1 } \\
\hline DQA1_0101 & 21 & 0,15 & 5 & 0,13 & 0,05 & 0,823 & 1,13 & 0,40 & 3,21 & 0,823 \\
\hline DQA1_0102 & 32 & 0,22 & 7 & 0,18 & 0,26 & 0,611 & 1,27 & 0,51 & 3,14 & 0,612 \\
\hline DQA1_0103 & 12 & 0,08 & 4 & 0,11 & 0,18 & 0,671 & 0,77 & 0,23 & 2,55 & 0,672 \\
\hline DQA1_0201 & 21 & 0,15 & 2 & 0,05 & 2,37 & 0,124 & 3,07 & 0,69 & 13,73 & 0,142 \\
\hline
\end{tabular}

$\mathrm{P}<0,05$. P < 0,05. Abs. - absolūtais biežums. Rel. - relatīvais biežums. $\chi^{2}-$ hī kvadrāta kritērijs. OR - izredžu attiecība. CI - ticamības intervāls. 
4. pielikums (turpinājums)

\begin{tabular}{|c|c|c|c|c|c|c|c|c|c|c|}
\hline & $\begin{array}{c}\text { TJA } \\
\text { pozitīvs } \\
\text { (alēlu skaits } \\
=144 \text { ) }\end{array}$ & 144 & $\begin{array}{l}\text { TJA negatīvs } \\
\text { (alêlu skaits } \\
=38 \text { ) }\end{array}$ & 38 & \multirow[t]{2}{*}{ hī kvadrātā } & \multirow[t]{2}{*}{$\mathrm{p}$} & \multirow[t]{2}{*}{ OR } & \multirow[t]{2}{*}{$\begin{array}{c}\text { CI 95\% } \\
\text { OR apakš. }\end{array}$} & \multirow[t]{2}{*}{$\begin{array}{c}\text { CI 95\% OR } \\
\text { augš. }\end{array}$} & \multirow[t]{2}{*}{$\mathrm{p}$} \\
\hline & biežums & $\begin{array}{c}\text { relatīvais } \\
\text { biežums }\end{array}$ & biežums & $\begin{array}{l}\text { relatīvais } \\
\text { biežums }\end{array}$ & & & & & & \\
\hline DQA1_0301 & 26 & 0,18 & 3 & 0,08 & 2,34 & 0,128 & 2,57 & 0,73 & 9,00 & 0,140 \\
\hline DQA1_0401 & 4 & 0,03 & 2 & 0,05 & 0,58 & 0,445 & 0,51 & 0,09 & 2,92 & 0,453 \\
\hline DQA1_0501 & 28 & 0,19 & 13 & 0,34 & 3,76 & 0,053 & 0,46 & 0,21 & 1,02 & 0,056 \\
\hline DQA1_0601 & 0 & 0,00 & 2 & 0,05 & 7,66 & 0,043 & 0,05 & 0,01 & 1,08 & 0,056 \\
\hline \multicolumn{11}{|l|}{ DQB1 } \\
\hline DQB1_0201_2 & 25 & 0,17 & 6 & 0,16 & 0,05 & 0,819 & 1,12 & 0,42 & 2,96 & 0,819 \\
\hline DQB1_0301 & 32 & 0,22 & 11 & 0,29 & 0,75 & 0,385 & 0,70 & 0,31 & 1,57 & 0,387 \\
\hline DQB1_0302 & 12 & 0,08 & 1 & 0,03 & 1,47 & 0,225 & 3,36 & 0,42 & 26,72 & 0,251 \\
\hline DQB1_0303 & 16 & 0,11 & 5 & 0,13 & 0,12 & 0,725 & 0,83 & 0,28 & 2,42 & 0,726 \\
\hline \multicolumn{11}{|l|}{ DQB1_0304 } \\
\hline DQB1_0305 & 1 & 0,01 & 0 & 0,00 & 0,27 & 0,606 & 0,80 & 0,03 & 20,15 & 0,895 \\
\hline DQB1_0401_2 & 3 & 0,02 & 0 & 0,00 & 0,81 & 0,370 & 1,90 & 0,10 & 37,67 & 0,672 \\
\hline DQB1_0501 & 27 & 0,19 & 9 & 0,24 & 0,46 & 0,497 & 0,74 & 0,32 & 1,75 & 0,498 \\
\hline DQB1_0502_4 & 4 & 0,03 & 0 & 0,00 & 1,08 & 0,299 & 2,47 & 0,13 & 46,81 & 0,548 \\
\hline DQB1_0601 & 1 & 0,01 & 1 & 0,03 & 1,04 & 0,308 & 0,26 & 0,02 & 4,24 & 0,343 \\
\hline DQB1_0602_8 & 23 & 0,16 & 5 & 0,13 & 0,18 & 0,669 & 1,26 & 0,44 & 3,55 & 0,669 \\
\hline HLA B27 & 15 & 0,21 & 3 & 0,16 & 0,24 & 0,623 & 1,40 & 0,36 & 5,46 & 0,625 \\
\hline
\end{tabular}

$\mathrm{P}<0,05$. $\mathrm{P}<0,05$. Abs. - absolūtais biežums. Rel. - relatīvais biežums. $\chi^{2}$ - hī kvadrāta kritērijs. OR - izredžu attiecība. CI - ticamības intervāls. 
HLA II klases alēlu genotipēšanas rezultāti salīdzinoši pacientu grupā ar hroniskām izmaiṇām MRI pret pacientiem ar izolētām aktīvām izmainām

\begin{tabular}{|c|c|c|c|c|c|c|c|c|c|c|}
\hline & $\begin{array}{c}\text { MRI } \\
\text { hroniskas } \\
\text { TML } \\
\text { iekaisuma } \\
\text { pazīmes } \\
\text { (alēlu skaits } \\
=100 \text { ) }\end{array}$ & 100 & $\begin{array}{l}\text { MRI TML } \\
\text { bez } \\
\text { hroniskām } \\
\text { pazīmēm, ar } \\
\text { izolētām } \\
\text { aktīva } \\
\text { iekaisuma } \\
\text { pazīmēm } \\
\text { (alęlu skaits } \\
\text { = 44) }\end{array}$ & 44 & \multirow[t]{2}{*}{ hī kvadrātā } & \multirow[t]{2}{*}{$\mathrm{p}$} & \multirow[t]{2}{*}{ OR } & \multirow[t]{2}{*}{$\begin{array}{c}\text { CI 95\% } \\
\text { OR } \\
\text { apakšs. }\end{array}$} & \multirow[t]{2}{*}{$\begin{array}{c}\text { CI 95\% OR } \\
\text { augš. }\end{array}$} & \multirow[t]{2}{*}{$\mathrm{p}$} \\
\hline & biežums & $\begin{array}{l}\text { relatīvais } \\
\text { biežums }\end{array}$ & biežums & $\begin{array}{l}\text { relatīvais } \\
\text { biežums }\end{array}$ & & & & & & \\
\hline \multicolumn{11}{|l|}{ DRB1 } \\
\hline DRB1_01 & 15 & 0,15 & 8 & 0,18 & 0,23 & 0,631 & 0,79 & 0,31 & 2,04 & 0,632 \\
\hline DRB1_04 & 10 & 0,10 & 3 & 0,07 & 0,38 & 0,539 & 1,52 & 0,40 & 5,81 & 0,542 \\
\hline DRB1_07 & 16 & 0,16 & 4 & 0,09 & 1,22 & 0,269 & 1,91 & 0,60 & 6,07 & 0,276 \\
\hline \multicolumn{11}{|l|}{ DRB1_08 } \\
\hline \multicolumn{11}{|l|}{ DRB1_09 } \\
\hline \multicolumn{11}{|l|}{ DRB1_10 } \\
\hline DRB1_11 & 10 & 0,10 & 10 & 0,23 & 4,14 & 0,042 & 0,38 & 0,14 & 0,99 & 0,047 \\
\hline DRB1_12 & 5 & 0,05 & 0 & 0,00 & 2,28 & 0,131 & 5,13 & 0,28 & 94,74 & 0,272 \\
\hline DRB1_13 & 18 & 0,18 & 3 & 0,07 & 3,07 & 0,080 & 3,00 & 0,84 & 10,77 & 0,092 \\
\hline DRB1_14 & 3 & 0,03 & 4 & 0,09 & 2,45 & 0,117 & 0,31 & 0,07 & 1,45 & 0,136 \\
\hline DRB1_15 & 19 & 0,19 & 8 & 0,18 & 0,01 & 0,908 & 1,06 & 0,42 & 2,63 & 0,908 \\
\hline DRB1_16 & 1 & 0,01 & 3 & 0,07 & 3,83 & 0,085 & 0,14 & 0,01 & 1,37 & 0,090 \\
\hline DRB1_17 & 3 & 0,03 & 1 & 0,02 & 0,06 & 0,807 & 1,33 & 0,13 & 13,15 & 0,807 \\
\hline
\end{tabular}


5. pielikums (turpinājums)

\begin{tabular}{|c|c|c|c|c|c|c|c|c|c|c|}
\hline & $\begin{array}{c}\text { MRI ar } \\
\text { hroniskām } \\
\text { TML } \\
\text { iekaisuma } \\
\text { pazīmēm } \\
\text { (alēlu } \\
\text { skaits = } \\
100)\end{array}$ & 100 & $\begin{array}{c}\text { MRI bez } \\
\text { hroniskām } \\
\text { TML } \\
\text { iekaisuma } \\
\text { pazīmēm, ar } \\
\text { izolētām } \\
\text { aktīva } \\
\text { iekaisuma } \\
\text { pazīmēm } \\
\text { (alēlu skaits } \\
=44 \text { ) } \\
\end{array}$ & 44 & \multirow[t]{2}{*}{ hī kvadrātā } & \multirow[t]{2}{*}{$\mathrm{p}$} & \multirow[t]{2}{*}{ OR } & \multirow[t]{2}{*}{$\begin{array}{c}\text { CI 95\% } \\
\text { OR } \\
\text { apakš. }\end{array}$} & \multirow[t]{2}{*}{$\begin{array}{c}\text { CI 95\% OR } \\
\text { augš. }\end{array}$} & \multirow[t]{2}{*}{$\mathrm{p}$} \\
\hline & biežums & $\begin{array}{c}\text { relatīvais } \\
\text { biežums }\end{array}$ & biežums & $\begin{array}{l}\text { relatīvais } \\
\text { biežums }\end{array}$ & & & & & & \\
\hline \multicolumn{11}{|l|}{ DQA1 } \\
\hline DQA1_0101 & 14 & 0,14 & 7 & 0,16 & 0,09 & 0,765 & 0,86 & 0,32 & 2,31 & 0,765 \\
\hline DQA1_0102 & 21 & 0,21 & 11 & 0,25 & 0,28 & 0,595 & 0,80 & 0,35 & 1,84 & 0,595 \\
\hline DQA1_0103 & 11 & 0,11 & 1 & 0,02 & 3,05 & 0,081 & 5,32 & 0,66 & 42,51 & 0,115 \\
\hline DQA1_0201 & 17 & 0,17 & 4 & 0,09 & 1,53 & 0,215 & 2,05 & 0,65 & 6,49 & 0,223 \\
\hline DQA1_0301 & 20 & 0,20 & 6 & 0,14 & 0,84 & 0,360 & 1,58 & 0,59 & 4,26 & 0,363 \\
\hline DQA1_0401 & 2 & 0,02 & 2 & 0,05 & 0,73 & 0,392 & 0,43 & 0,06 & 3,15 & 0,405 \\
\hline DQA1_0501 & 15 & 0,15 & 13 & 0,30 & 4,13 & 0,042 & 0,42 & 0,18 & 0,98 & 0,046 \\
\hline DQA1_0601 & & & & & & & & & & \\
\hline
\end{tabular}


5. pielikums (turpinājums)

\begin{tabular}{|c|c|c|c|c|c|c|c|c|c|c|}
\hline & $\begin{array}{c}\text { MRI ar } \\
\text { hroniskām } \\
\text { TML } \\
\text { iekaisuma } \\
\text { pazīmēm } \\
\text { (alēḷu } \\
\text { skaits = } \\
100 \text { ) }\end{array}$ & 100 & $\begin{array}{c}\text { MRI bez } \\
\text { hroniskām } \\
\text { TML } \\
\text { iekaisuma } \\
\text { pazīmēm, ar } \\
\text { izolētām } \\
\text { aktīiva } \\
\text { iekaisuma } \\
\text { pazīmēm } \\
\text { (alēlu skaits } \\
=44 \text { ) }\end{array}$ & 44 & hī kvadrātā & $\mathrm{p}$ & OR & $\begin{array}{c}\text { CI 95\% } \\
\text { OR } \\
\text { apakš. }\end{array}$ & $\begin{array}{c}\text { CI 95\% OR } \\
\text { augš. }\end{array}$ & $\mathrm{p}$ \\
\hline & biežums & $\begin{array}{l}\text { relatīvais } \\
\text { biežums }\end{array}$ & biežums & $\begin{array}{c}\text { relatīvais } \\
\text { biežums }\end{array}$ & & & & & & \\
\hline \multicolumn{11}{|l|}{ DQB1 } \\
\hline DQB1_0201_2 & 21 & 0,21 & 4 & 0,09 & 3,02 & 0,082 & 2,66 & 0,86 & 8,27 & 0,091 \\
\hline DQB1_0301 & 17 & 0,17 & 15 & 0,34 & 5,16 & 0,023 & 0,40 & 0,18 & 0,89 & 0,026 \\
\hline DQB1_0302 & 11 & 0,11 & 1 & 0,02 & 3,05 & 0,081 & 5,32 & 0,66 & 42,51 & 0,115 \\
\hline DQB1_0303 & 10 & 0,10 & 6 & 0,14 & 0,41 & 0,522 & 0,70 & 0,24 & 2,07 & 0,524 \\
\hline \multicolumn{11}{|l|}{ DQB1_0304 } \\
\hline DQB1_0305 & 0 & 0,00 & 1 & 0,02 & 2,29 & 0,130 & 0,14 & 0,01 & 3,61 & 0,239 \\
\hline DQB1_0401_2 & 2 & 0,02 & 1 & 0,02 & 0,01 & 0,916 & 0,88 & 0,08 & 9,94 & 0,916 \\
\hline DQB1_0501 & 18 & 0,18 & 9 & 0,20 & 0,12 & 0,728 & 0,85 & 0,35 & 2,08 & 0,728 \\
\hline DQB1_0502_4 & 2 & 0,02 & 2 & 0,05 & 0,73 & 0,392 & 0,43 & 0,06 & 3,15 & 0,405 \\
\hline DQB1_0601 & 0 & 0,00 & 1 & 0,02 & 2,29 & 0,130 & 0,14 & 0,01 & 3,61 & 0,239 \\
\hline DQB1_0602_8 & 19 & 0,19 & 4 & 0,09 & 2,24 & 0,135 & 2,35 & 0,75 & 7,34 & 0,144 \\
\hline
\end{tabular}

$\mathrm{P}<0,05$. P $<0,05$. Abs. - absolūtais biežums. Rel. - relatīvais biežums. $\chi^{2}$ - hī kvadrāta kritērijs. OR - izredžu attiecība. CI - ticamības intervāls. 


\section{PĒTĪJUMA PROTOKOLS}

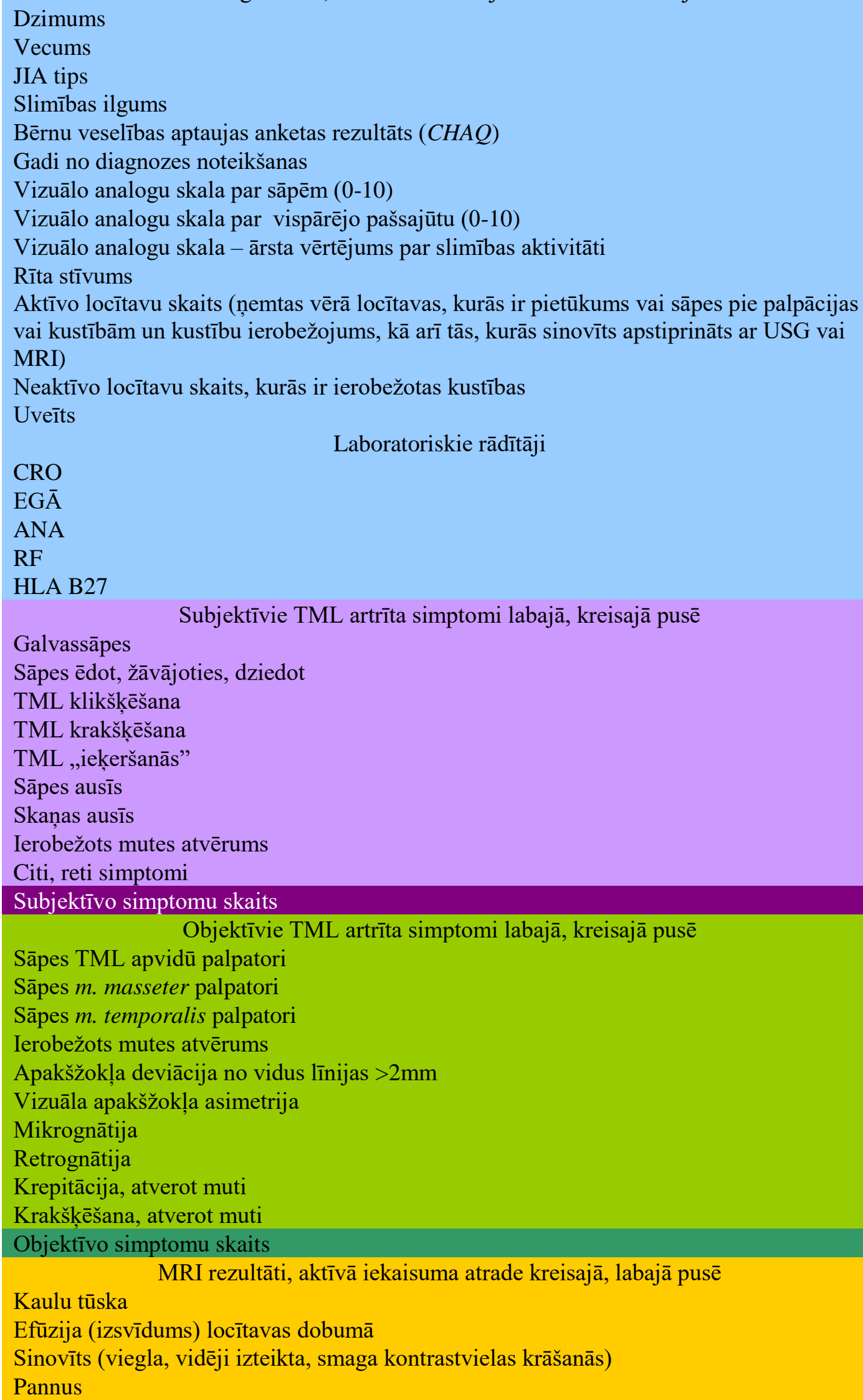


MRI hroniskā iekaisuma izmaiņas kreisajā, labajā pusē Apakšžokḷa kondiḷa galviņas deformācija

Bedrìtes saplacinājums

Osteofiti

Erozijas

Pacientu dalījums grupās atkarībā no MRI rezultāta

Izolētas aktīvas izmainas

Izolētas hroniskas izmainas

Aktīvu un hronisku izmainu kombinācija

MRI bez izmain̄ām

Pazīmju skaits 